\title{
WestVirginiaUniversity
}

THE RESEARCH REPOSITORY @ WVU

Graduate Theses, Dissertations, and Problem Reports

2018

\section{A study of the durability in class-M concrete due to chlorid permeability}

Amelia Suzanne Riley

Follow this and additional works at: https://researchrepository.wvu.edu/etd

\section{Recommended Citation}

Riley, Amelia Suzanne, "A study of the durability in class-M concrete due to chlorid permeability" (2018). Graduate Theses, Dissertations, and Problem Reports. 3981.

https://researchrepository.wvu.edu/etd/3981

This Problem/Project Report is protected by copyright and/or related rights. It has been brought to you by the The Research Repository @WVU with permission from the rights-holder(s). You are free to use this Problem/Project Report in any way that is permitted by the copyright and related rights legislation that applies to your use. For other uses you must obtain permission from the rights-holder(s) directly, unless additional rights are indicated by a Creative Commons license in the record and/ or on the work itself. This Problem/Project Report has been accepted for inclusion in WVU Graduate Theses, Dissertations, and Problem Reports collection by an authorized administrator of The Research Repository @ WVU. For more information, please contact researchrepository@mail.wvu.edu. 
A Study of the Durability in Class-M Concrete due to Chloride Permeability

\author{
Amelia Riley
}

Problem Report submitted

to the College of Engineering and Mineral Resources

at West Virginia University

in partial fulfillment of the requirements for the degree of

Master of Science in

Civil Engineering / Structural

\author{
Roger H.L. Chen, Ph.D., Chair \\ P. V. Vijay, Ph. D. \\ Kakan Dey, Ph. D. \\ Department of Civil and Environmental Engineering \\ Morgantown, West Virginia \\ 2018
}

Keywords: Slag, SCC, Concrete, Ponding, Chloride Permeability 


\section{ABSTRACT}

\section{A STUDY OF THE DURABILITY IN CLASS-M CONCRETE DUE TO CHLORIDE PERMEABILITY}

\section{AMELIA RILEY}

The service life of reinforced concrete structures is dependent on the integrity of the steel within the concrete. Over time, due to exposure, chloride and other minerals can penetrate the concrete. Once these materials get to the reinforcing steel, the chloride and oxygen start to corrode and deteriorate the steel. This deterioration will cut the service life of a bridge down dramatically. To prevent this, the permeability of concrete was studied to determine the service life of one of the new Class-M concretes and a Self-Consolidating Concrete (SCC) mix designs; both developed to produce higher quality concrete.

This paper looks at the previous research done into the cementitious replacement of slag and SCC's effect on permeability. A replacement of cement with $50 \%$ slag was used to create the slag concrete, and a 9\% addition of silica fume was used for the SCC concrete. During this study, three different concrete mix designs were included, concrete with 50\% slag replacement, an SCC, and an ordinary Portland cement (OPC) concrete. The permeabilities of these three concrete mixes were tested using three different methods. A ponding experiment, which allows salty water to slowly penetrate concrete samples, the Rapid Chloride Penetration Testing, which uses current to push chloride through a concrete sample, and lastly, a Virtual RCPT method, which is a computer model that uses the mix design quantities to predict the permeability of concrete. The diffusion chloride coefficients of the concrete were obtained. These results were then used with the Life 365 software and a NIST service life prediction model to predict the service life of each concrete mix design. The results show that OPC has a service life in the range of 16-22 years. Slag has a service life range between 47-48.5 years, and SCC has a range of 60-252 years. This shows that OPC has the lowest service life range when looking at chloride permeability and that SCC produces the largest service life. 


\section{ACKNOWLEDGMENTS}

I would like to thank my advisor Dr. Chen as well as my fellow research team, Guadalupe Leon, Seyednavid Mardmomen, and Tadamon Mohammed, for their constant guidance and help through this research. I would also like to thank my committee members, Dr. P.V. Vijay and Dr. Kakan Dey who were not only wonderful teachers but who also provided their guidance and time to help complete this problem report. Also, I would like to acknowledge the financial support provided to me by the WVU Physics Department, most notably from Dr. Miller and Greg Puskar. I would also like to recognize the time and knowledge given to me by the Civil and Environment Engineering Department, most notably Karen Buzby and David Turner, who went above and beyond to help me complete my research.

Most importantly I would like to thank my parents, Melanie and Terry Riley for their unending love and support throughout my entire academic career, without them none of this would be possible. I would also like to thank my sister, Caitlin Hanna for her constant support and encouragement. Lastly, I would like to thank Logan Kaptis for being my rock the last two years, and for providing continuous love and support. 


\section{TABLE OF CONTENTS}

Abstract

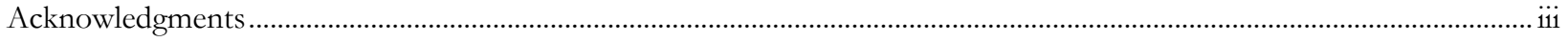

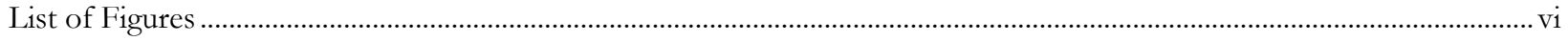

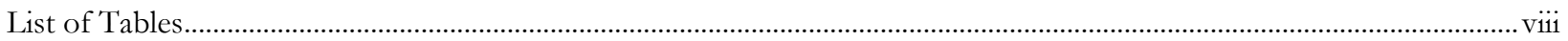

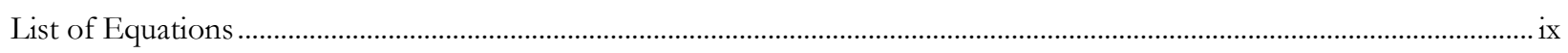

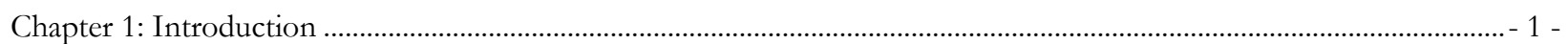

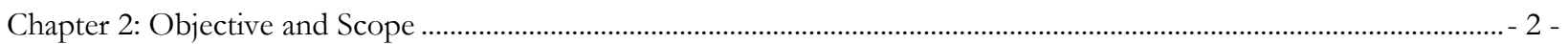

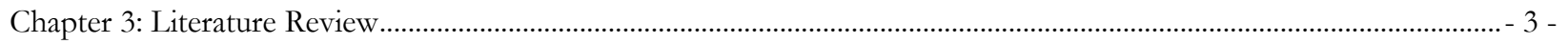

3.1 Supplementary Cementitious Material (SCM) …................................................................................................... 3 -

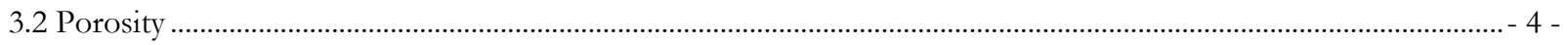

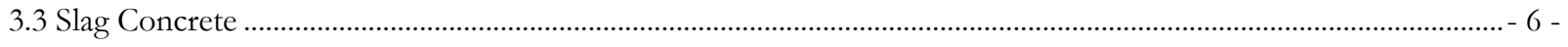

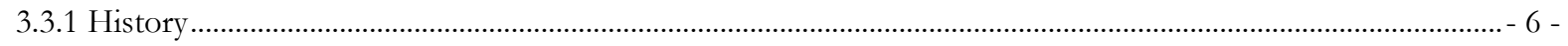

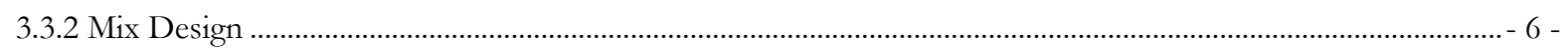

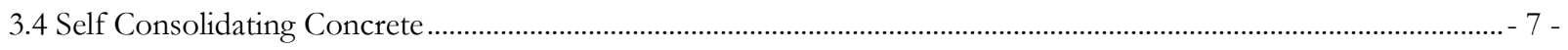

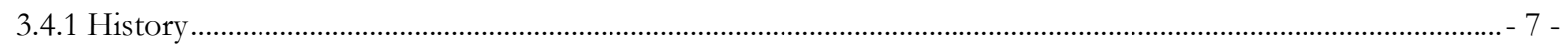

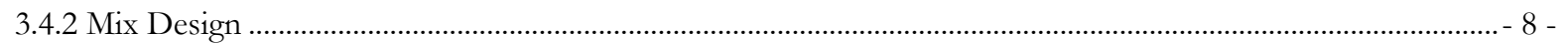

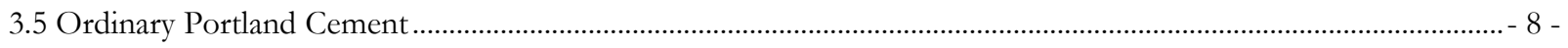

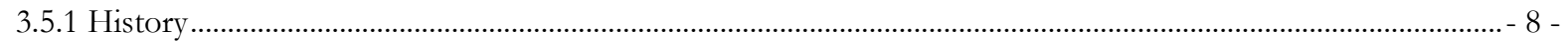

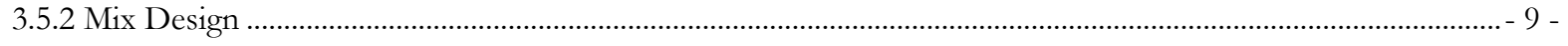

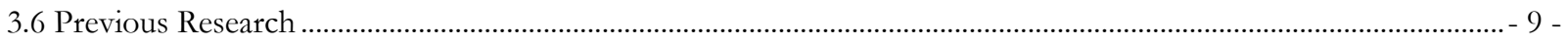

3.6.1 Bilir, Turhan. "Effects of Non-Ground Slag and Bottom Ash as Fine Aggregate on Concrete Permeability

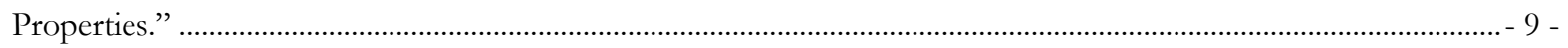

3.6.2 A Study of the Basic Engineering Properties of Slag Cement Concrete and its Resistance to Seawater

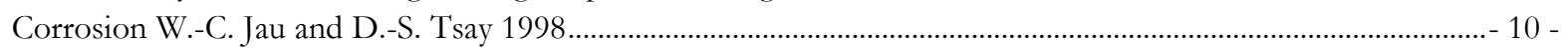

3.6.3 The Pore Structure of Cement Paste Blended with Fly Ash Zhuqing Yu*, Guange ye, 2013 ........................-11 -

3.6.4 Service Life Prediction: Theorecrete, Labcrete and Realcrete Approches, Roberto J. Torrent, 2013 ............- 12 -

3.6.5 Enhancing the Service Life of Concrete Exposed to Chloride Attack, Zhengtian Song, 2014 .....................- 14 -

3.6.6 A virtual rapid chloride permeability test, Dale P. Bentz 2007 .......................................................................- 16 -

3.6.7 Models for chloride ingress into concrete- from Collepardi to today, Lars-Olof Nilsson 2009.....................- 18 -

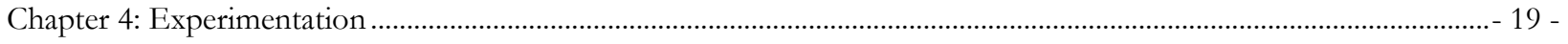

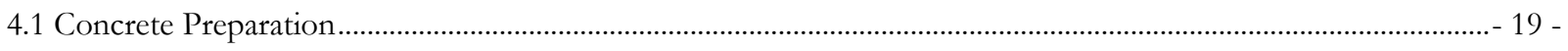

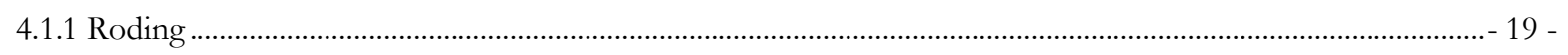

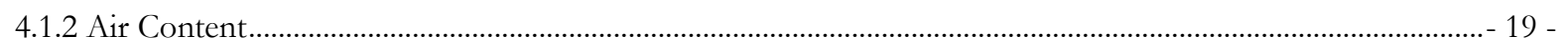

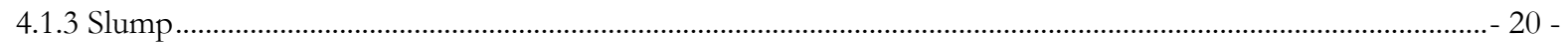

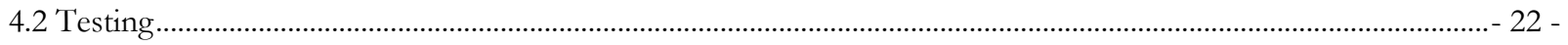




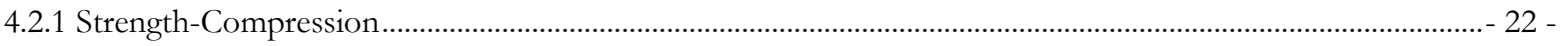

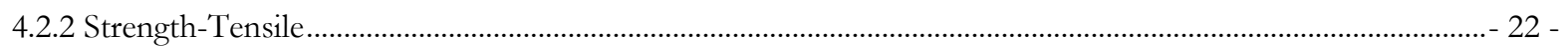

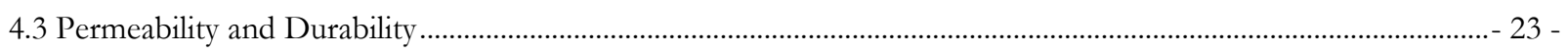

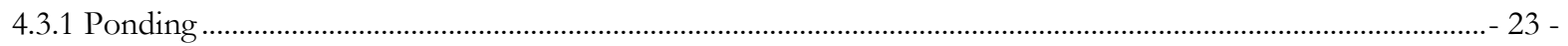

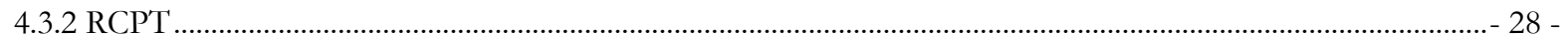

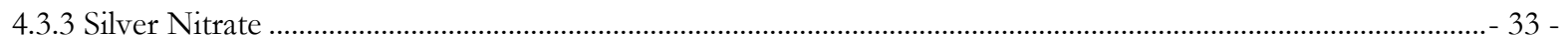

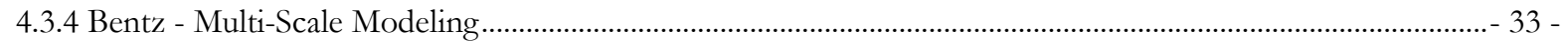

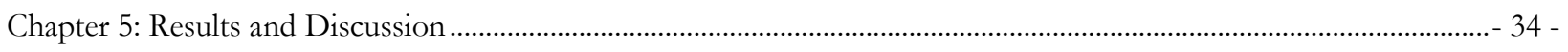

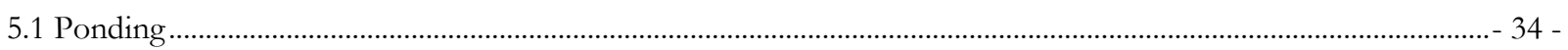

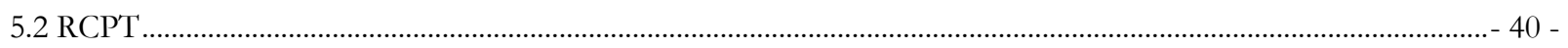

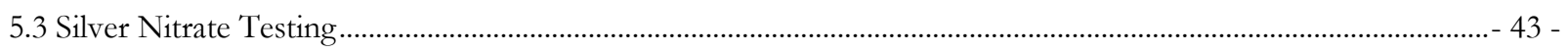

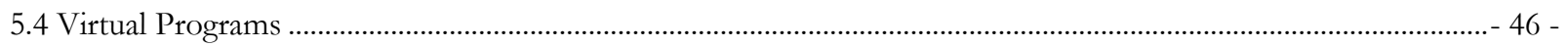

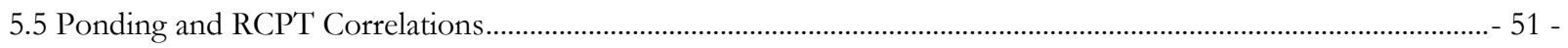

5.6 Permeability's effect on Durability, Through Service Life Calculations ..............................................................- 53 -

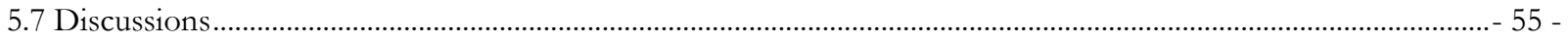

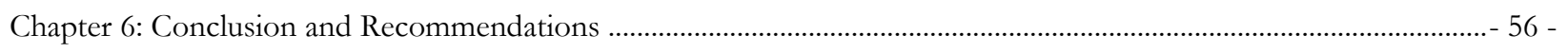

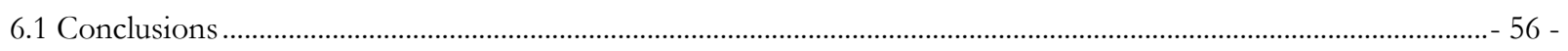

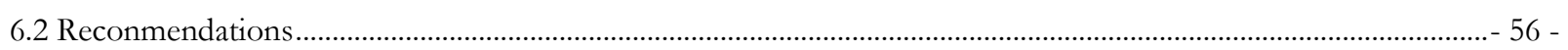

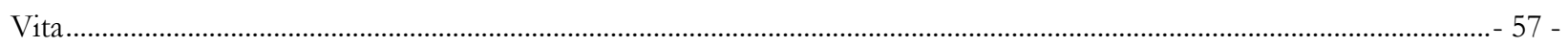

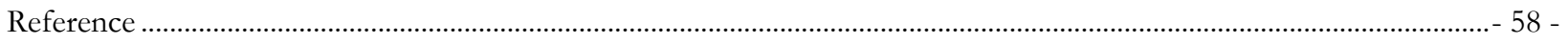




\section{LIST OF FIGURES}

FIGURE 1: EXPLANATION OF WHY WE HAVE ENTRAINMENT PORES. (AIR ENTRAINMENT VERSUS AIR ENTRAPMENT, 2012) - 4 -

FIGURE 2: REPRESENTATION OF THE BENEFIT OF USING A PARTIAL SLAG REPLACEMENT. (LAFARGE AT A GLANCE, 2015). $-5-$ FIGURE 3: DISADVANTAGES OF ORDINARY CONCRETE PLACEMENT. ${ }^{13}$ $-7-$

FIGURE 4 RESULTS FROM THE RCPT TESTING ON DIFFERENT RATIOS OF SLAG CONCRETE, DONE BY TURHAN BILIR. S SERIES STANDS FOR SLAG, B SERIES STANDS FOR BOTTOM ASH AND SB STANDS FOR SLAG + BOTTOM ASH, THE WATER-CEMENT RATIO IS $0.43 .{ }^{\circ}$... 10 FIGURE 5: RESULTS FROM W.-C. JAU1 AND D.-D. TSAY'S RESEARCH. (TSAY 1998) ....................................- 11 FIGURE 6: THE RELATIONSHIP OF CURING TIME TO POROSITY FOR DIFFERENT AMOUNTS OF FLY ASH. ${ }^{15}$ -11 -

FIGURE 7: EFFECT OF CEMENT CHARACTERISTICS AND WATER-CEMENT RATIO ON THE K. PARAMETER USED IN SERVICE LIFE PREDICTIONS. (TORRENT, 2013)............................................... 13 FIGURE 8: VERTICAL PRESSURE CHAMBER FOR DETERMINING AIR CONTENT OF FRESHLY MIXED CONCRETE. ${ }^{16}$ $19-$ FIGURE 9(A): AIR CONTENT FOR THE OPC. $20-$ FIGURE 10: SLUMP SPREAD TEST PREFORMED ON THE SCC CASTING USED IN THIS RESEARCH..- 21 FIGURE 11: SLUMP TEST RESULTS FOR OPC CONCRETE CASTING. $21-$ FIGURE 12: SET-UP AND PREDICTED FAILURE PATH OF A SPECIMEN UNDERGOING TENSILE-

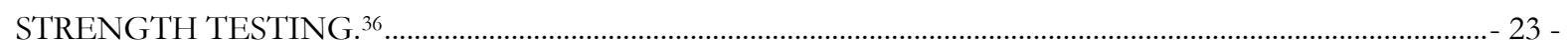
FIGURE 13(A): PONDING SAMPLE WITH DIKE, UNCOVERED ………………………………………………….....- 24 -

FIGURE 14: REFERENCE TABLE USED TO OBTAIN THE FORMULA FOR CALCULATING THE CONCENTRATION OF CHLORIDE IN CONCRETE SAMPLES. $26-$ FIGURE 15: SAMPLE ON THE RIGHT HAS JUST BEEN STIRRED FOR THE REQUIRED FIVE MINUTES AND THE SAMPLE ON THE LEFT HAS BEEN LEFT TO LEACH FOR FIVE MINUTES.......................- 27 FIGURE 16: THE PROCESS OF DETERMINING THE CHLORIDE LEVEL, BY USING THE ELECTROPROBE TO DETERMINE THE MV READING OF A SAMPLE ...................................................................... 27 FIGURE 17: INSIDE OF VOLTAGE CELL, WITH CONDUCTIVE MESH IN PLACE..........................................- 29 FIGURE 18: VOLTAGE CELL FASTENED WITH C-CLAMPS.......................................................................................- 30 FIGURE 19: VOLTAGE CELLS ATTACHED WITH BOLTS. ……………………………………………...............- 30 FIGURE 20: TEMPERATURE CHANGE DURING RCPT............................................................................................- 31 FIGURE 21: OUTPUT DATA FROM RCPT, MACHINE GIVES THE TIME THE TEST HAS BEEN RUNNING, CURRENT, VOLTAGE, AND TOTAL CHARGE PASSED. ............................................................................- 32 -

FIGURE 22: GRAPH OF THE CHLORIDE CONCENTRATION OF SCC1, VS. THE DEPTH OF THE SAMPLE (MM). $34-$

FIGURE 23: GRAPH OF THE CHLORIDE CONCENTRATION PER GRAM OF OPC 2 VERSUS DEPTH (MM). $35-$

FIGURE 24: GRAPH OF THE CHLORIDE CONCENTRATION PER GRAM VS. DEPTH (MM) FOR SAMPLE SLAG 1. $-35-$

FIGURE 25: GRAPH OF THE CONCENTRATION OF CHLORIDE PER GRAM OF SAMPLE VS. DEPTH OF SAMPLE (MM). - 36 FIGURE 26: TEST RESULTS FROM THE CHLORIDE CONCENTRATING TESTING. ....................................- 36 FIGURE 27: TEST RESULTS FROM THE CHLORIDE CONCENTRATION TESTING....................................- 37 FIGURE 28: CHLORIDE CONCENTRATION PER GRAM OF SAMPLE VS. DEPTH(MM) FOR THE RAW DATA. -37 FIGURE 29: CONCENTRATION OF CHLORIDE VS. DEPTH (MM) PRODUCED WITH THE BEST FIT LINE FROM EACH PREVIOUS GRAPH. $38-$ 
FIGURE 30: THE CHLORIDE CONCENTRATION PER GRAM OF SAMPLE VS. DEPTH (MM), PRODUCED FROM THE BEST FIT LINE OF EACH SAMPLE, WITH THE OUTLINER DATA REMOVED AND THE AVERAGE TAKEN OF THE REMAINING SAMPLES FOR EACH MIXTURE TYPE. -38 -

FIGURE 31: GRAPH OF THE CONCENTRATION OF CHLORIDE PER GRAM OF SAMPLE VS. DEPTH (MM), THE DATA IS OF THE BEST FIT LINE, WITH THE OUTLINERS AND THE BASE CHLORIDE LEVEL REMOVED... -39 FIGURE 32: EXAMPLE OF THE INTEGRAL CHLORIDE CONTENT CALCULATION. (MCGRATH, 1999)- 40

FIGURE 33: RCPT TEST RESULTS COMPARING CURRENT (A) AGAINST TIME (MIN). .............................- 41 FIGURE 34: THE RCPT DATA OF CHARGE PASSED (COULOMBS) VERSUS TIME (MIN) ............................- 41 FIGURE 35: CURRENT PASSED THROUGH A 51MM SAMPLE VERSUS THE TIME FOR ALL SAMPLES.. - 42

FIGURE 36: RCPT DATA OF CHARGED PASSED OF A 51MM SAMPLE (COULOMBS) VERSUS TIME (MIN).

FIGURE 37: OPC1 RCPT SAMPLES AFTER SILVER NITRATE IWAS APPLIED.

FIGURE 38: OPC RCPT SAMPLES AFTER SILVER NITRATE WAS APPLIED. .......................................................- 45 -

FIGURE 39: SLAG RCPT SAMPLES AFTER SILVER NITRATE WAS APPLIED....................................................- 45 -

FIGURE 40: SCC RCPT SAMPLES AFTER SILVER NITRATE WAS APPLIED. .......................................................- 45 -

FIGURE 41: THE WATER CEMENT RATIO AND THE SILICA FUME PERCENT WAS ADJUSTED TO OBSERVE THE SERVICE LIFE. .....................................................................................................................- 49 -

FIGURE 42: THE VOLUME FRACTION OF AGGREGATE AND THE SILICA FUME REPLACEMENT WAS ADJUSTED TO OBSERVE THE SERVICE LIFE. ……………………………..............................................- 49 -

FIGURE 43: DEGREE OF HYDRATION AND SILICA FUME REPLACEMENT WERE ADJUSTED TO

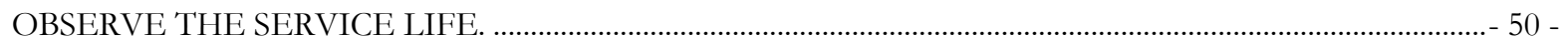

FIGURE 44: DEGREE OF HYDRATION AND SILICA FUME REPLACEMENT WERE ADJUSTED TO OBSERVE THE SERVICE LIFE. ...........................................................................................................................- 50 -

FIGURE 45: WATER CEMENT RATIO AND SILICA FUME REPLACEMENT WERE ADJUSTED TO

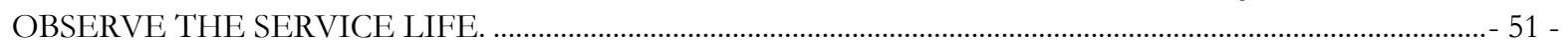

FIGURE 46: RELATIONSHIP BETWEEN INTEGRAL CHLORIDE CONTENT AND THE CHARGE PASSED (COULOMBS). -52 FIGURE 47: RELATIONSHIP BETWEEN MIGRATION COEFFICIENT AND DIFFUSION COEFFICIENT.43 52 -

FIGURE 48: SERVICE LIFE ESTIMATIONS, USING THE LIFE-365 PROGRAM ${ }^{32}$ $-54-$ 


\section{LIST OF TABLES}

TABLE 1: COMPOSITION OF PORTLAND CEMENT WITH CHEMICAL COMPOSITION AND WEIGHT PERCENT. ${ }^{6}$

TABLE 2: MINIMUM AREA OF FINISHED SURFACE FOR MICROSCOPICAL MEASUREMENT (ASTM C457)

TABLE 3: MIX DESIGN FOR MASS CONCRETE WITH 50\% SLAG REPLACEMENT.

TABLE 4: SCC MIX DESIGN, USED IN CASTING.

TABLE 5: OPC MIX DESIGN, USED IN THIS RESEARCH.

TABLE 6: CHLORIDE ION PENETRABILITY BASED ON CHARGE PASSED. ${ }^{3}$

$-4-$

$-6-$

$-8-$

$-9-$

TABLE 7: POROSITY PERCENTAGES OF DIFFERENT FLY ASH SAMPLES. ${ }^{35}$

$-10-$

$-12-$

TABLE 8: DESCRIPTION OF DIFFERENT SERVICE LIFE PREDICTION MODELS (SONG, 2014) 29 - 14 -

TABLE 9: PREDICTED INFLUENCE ON SERVICE LIFE OF CONCRETE IN THE NUMERICAL MODEL, BASED OFF THE CS, N AND DA PARAMETERS. (SONG, 2014)

TABLE 10: CHLORIDE INGRESS MEASUREMENTS OF CONCRETE (CEMENT CONTENT OF $\left.400 \mathrm{KG} / \mathrm{M}^{\wedge} 3\right)^{29}$

TABLE 11: COMPARISON BETWEEN PREDICTED AND EXPERIMENT PERMEABILITY OF DIFFERENT CONCRETE DESIGNS. (BENTZ, 2007)

-17 -

TABLE 12: CHLORIDE DIFFUSION COEFFICIENT FOR PONDING SAMPLES.

$-39-$

TABLE 13: CHLORIDE INTEGRAL CHLORIDE CONTENT FOR EACH SPECIMEN.

-40 -

TABLE 14: ASTM C1202 USES THE TOTAL PASSED CHARGE TO DETERMINE THE PENETRABILITY OF THE CONCRETE. ${ }^{3}$

TABLE 15: CHLORIDE MIGRATION COEFFICIENT FOR EACH RCPT TESTING.

TABLE 16: CONSTANT VALUES USED IN VIRTUAL PREDICTIONS.

TABLE 17: SERVICE LIFE PARAMETERS AND RESULTS. ${ }^{46}$ - 48

TABLE 18: CHLORIDE EXPOSURE PREDICTION FOR AN URBAN BRIDGE IN CHARLESTON WEST VIRGINIA 32

TABLE 19: CHLORIDE DIFFUSION COEFFICIENT PREDICTIONS. ${ }^{32}$

TABLE 20: CHLORIDE DIFFUSION COEFFICIENT COMPARISON. *THE VALUES FOR RCPT CAME FROM THE CORRELATION BETWEEN CHLORIDE MIGRATION COEFFICIENT AND CHLORIDE DIFFUSION COEFFICIENT. 55 -

TABLE 21: COMPARISON OF SERVICE LIFE RESULTS FROM BOTH PROGRAMS. - 55 - 


\section{LIST OF EQUATIONS}

EQUATION 1: $\mathrm{CA}(\mathrm{OH})_{2}+\mathrm{H}_{4} \mathrm{SIO}_{4} \rightarrow \mathrm{CAH}_{2} \mathrm{SIO}_{4} \cdot 2 \mathrm{H}_{2} \mathrm{O}$ $-3-$

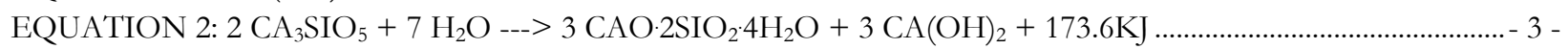
EQUATION 3: FICK'S 2ND LAW SOLUTION TO CALCULATE THE SERVICE LIFE. (TORRENT, 2013)..- 12 EQUATION 4: LIFE-365 MODEL'S PROPOSED D FUNCTION. ${ }^{28}$ $-13-$ EQUATION 5: D FUNCTION CREATED IN THE REALCRETE METHODS. ${ }^{28}$................................................... 14 EQUATION 6: EQUATION TO DETERMINE THE DA PARAMETER. ${ }^{29}$ $-15-$ EQUATION 7: EQUATION USED TO DETERMINE THE SERVICE LIFE. 29 $-15-$ EQUATION 8: BENTZ EQUATION FOR THE LOG10(D) FUNCTION. (BENTZ, 2007) ${ }^{30}$................................- 17 -

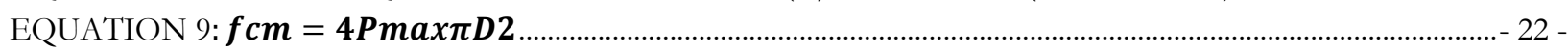

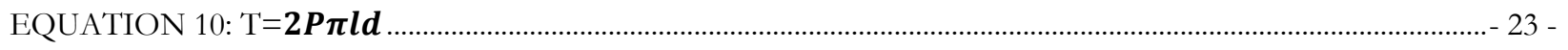

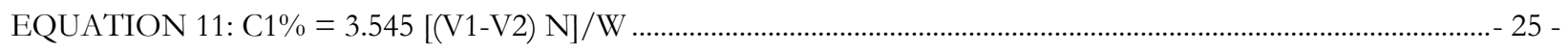

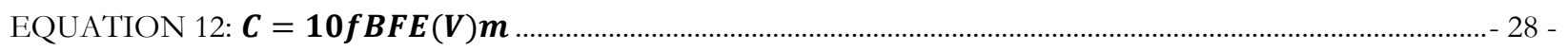

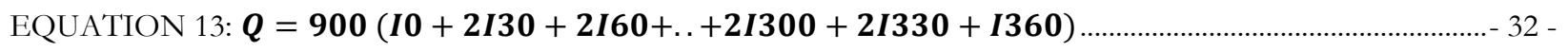
EQUATION 14: CALCULATION OF CHLORIDE DIFFUSION COEFFICIENT ${ }^{42}$............................................... 39 -

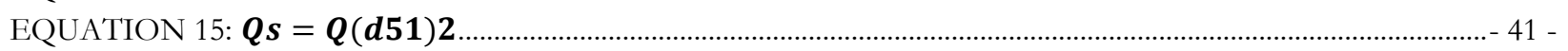
EQUATION 16: CALCULATIONS FOR THE E PARAMETER OF THE CHLORIDE MIGRATION COEFFICIENT ${ }^{41}$ $43-$ EQUATION 17: THE FORMULA TO OBTAIN THE ALPHA PARAMETER ${ }^{41}$...........................................................- 43 EQUATION 18: CALCULATION FOR THE CHLORIDE MIGRATION COEFFICIENT ${ }^{41}$.................................- 44 - 


\section{CHAPTER 1: INTRODUCTION}

The United States sees a vast variety and severity of the weather. In Northern states, ice is a problem treated with brine, rock salt, calcium chloride as well as other types of chemicals. Sodium Chloride, found in many de-icing systems, will penetrate the concrete at a steady rate and is observed through two commonly used methods. The first, ponding, was the traditional method of determining the penetration of sodium chloride through concrete. The technique is slow to receive data, and the testing can be time-consuming. The second method, rapid chloride penetration testing, RCPT, was developed to speed up the process of chloride penetration by using a voltage to force a sodium chloride mixture through the concrete. This procedure also allows for precise distribution of sodium chloride through silver nitrate testing. The distribution is an advantage over ponding which shows a step distribution. The rate of permeability in both methods is used to predict the durability of concrete. The two methods are not usually done at the same time, due to the longevity that ponding takes. They are also not typically compared since ponding produces a chloride concentration and RCPT produced a total passed charge. However, in 2007 Dale P. Bentz, released a paper and program that created a virtual immediate chloride permeability test that should be comparable to the relationship of different concrete produced in both ponding and RCPT.

This literature and preliminary review aim to understand the permeability and durability of a new Class M concrete. The new Class M concrete is a class of concrete that is still being developed. The new Class $\mathrm{M}$ concrete is produced to decrease the thermal heat produced during the hydration of concrete. This benefit allows concrete to hydrate at a lower core temperature. For large concrete members, lower core temperature is crucial since the difference between ambient temperature and core temperature can create thermal cracking along the edges and corners of concrete members. Ultimately, this new class of concrete will reduce cracking in the first twenty-four to forty-eight hours of hydration. A Class M concrete will save money and time, as it eliminates the need for the thermal framework in many cases. All aspects of a new concrete must be understood to predict how it will perform short term as well as long-term. Not only is the concrete a concern but its ability to protect the interior reinforcement will determine the longevity of any reinforced concrete structure. Most structures use some reinforcements, and it's paramount that they can sustain the predicted structural strength and stability over estimated service life. 


\section{CHAPTER 2: OBJECTIVE AND SCOPE}

A literature review of the effect cementitious substitution, in concrete, has on permeability and durability was conducted. The review covers varying water-cement ratios and percentages of fly ash and slag substituting. A study of the ASTM testing methods was performed so that the best methods of preparations and testing were used for measuring the characteristics of concrete. The literature review lays the groundwork for this research.

The objective of this research is to observe and determine the chloride permeability through ponding, rapid chloride permeability testing, virtual rapid chloride permeability testing, and silver nitrate testing. Ordinary Portland cement mixture was compared to a new Class M slag concrete mixture as well as a self-consolidation concrete mixture. The relationship between the types of concrete for both ponding and rapid chloride testing were compared to the virtual test.

The scope of the research covers durability directly related to the permeability of chloride in all three concrete mix designs. The results are specific for the three mix designs, an ordinary Portland cement concrete, a 50\% slag replacement concrete and a 9\% silica fume replacement. The chemical composition of the OPC, slag and silica fume concrete were kept constant since variations of their composition can affect the permeability. All the chemical admixtures were also kept constant through the research, and adjusting the admixtures can also alter the permeability. 


\section{CHAPTER 3: LITERATURE REVIEW}

\subsection{SUPPLEMENTARY CEMENTITIOUS MATERIAL (SCM)}

Supplementary cementitious materials (SCM) are used with Portland cement to create a better cementitious material. SCM changes concrete hardening properties through pozzolans and hydraulic materials. Pozzolans are a class of siliceous or siliceous and aluminous materials. With the addition of water, these materials have little to no cementitious benefits. However, when pozzolans are finely divided, they can create a reaction between calcium hydroxide, from the ordinary Portland cement (OPC,) and silicic acid which produces a product of calcium silicate hydrate.

$$
\text { Equation 1: } \mathrm{Ca}(\mathrm{OH})_{2}+\mathrm{H}_{4} \mathrm{SiO}_{4} \rightarrow \mathrm{CaH}_{2} \mathrm{SiO}_{4} \cdot 2 \mathrm{H}_{2} \mathrm{O}
$$

Pozzolanic reactions take a long time to be completed and must have ample amounts of free calcium to continue to develop. The reaction is irreversible and can be dated back to the Ancient Romans who used this process in the creation of their concrete structures, most notable still standing is the Pantheon, more modern examples of pozzolanic reactions include the reaction of slag with OPC.

Cement and SCM's that react to the water in the concrete mixture produce mineral hydrates, which are then stable and non-water soluble. These reactions are referred to as the hydration process of concrete. The most common of these reactions are OPC and fly ash. OPC has more than five different materials that go through the hydration process,

$\begin{array}{ccc}\text { Cement Compound } & \text { Weight Percentage } & \text { Chemical Formula } \\ \text { Tricalcium silicate } & 50 \% & \mathrm{Ca}_{3} \mathrm{SiO}_{5} \text { or } 3 \mathrm{CaO} \cdot \mathrm{SiO}_{2} \\ \text { Dicalcium silicate } & 25 \% & \mathrm{Ca}_{2} \mathrm{SiO}_{4} \text { or } 2 \mathrm{CaO} \cdot \mathrm{SiO}_{2} \\ \text { Tricalcium aluminate } & 10 \% & \mathrm{Ca}_{3} \mathrm{Al}_{2} \mathrm{O}_{6} \text { or } 3 \mathrm{CaO} \cdot \mathrm{Al}_{2} \mathrm{O}_{3} \\ \text { Tetracalcium aluminoferrite } & 10 \% & \mathrm{Ca}_{4} \mathrm{Al}_{2} \mathrm{Fe}_{2} \mathrm{O}_{10} \text { or } 4 \mathrm{CaO} \cdot \mathrm{Al}_{2} \mathrm{O}_{3} \cdot \mathrm{Fe}_{2} \mathrm{O}_{3} \\ \text { Gypsum } & 5 \% & \mathrm{CaSO}_{4} \cdot 2 \mathrm{H}_{2} \mathrm{O}\end{array}$

Table 1: Composition of Portland cement with chemical composition and weight percent. ${ }^{6}$

the most common is the reaction of tricalcium silicate with water, which results in the production of calcium silicate hydrate, calcium hydroxide, and heat, the reaction shown below.

$$
\text { Equation 2: } 2 \mathrm{Ca}_{3} \mathrm{SiO}_{5}+7 \mathrm{H}_{2} \mathrm{O}--->3 \mathrm{CaO} \cdot 2 \mathrm{SiO}_{2} \cdot 4 \mathrm{H}_{2} \mathrm{O}+3 \mathrm{Ca}(\mathrm{OH})_{2}+173.6 \mathrm{~kJ}
$$

The reaction time for SCM is based on the fineness of the material, the finer the material, the faster the reactions, and the ratios of water-cement and cement-SCM. Both ratios have been studied to create the optimal mixtures for each SCM. 


\subsection{POROSITY}

Porosity in concrete is inversely proportional to the density of concrete and directly proportional to the permeability. The porosity of concrete is made of two different types of pores; capillary pores and pores created by air voids. Capillary pores are created from water particle's position and movement in concrete. Capillary pores take up most of the voids, and range on average from $10 \mathrm{~nm}$ to $50 \mathrm{~nm}$ for low water ratios and can be as large as $5 \mu \mathrm{m}$ for high water ratios. Air voids are composed of both entrapped as well as entrained voids. Entrapped voids are created through the concrete mixing process and should be minimized if concrete is mixed properly. Entrapped voids have a large range of size and can be as large as $3 \mathrm{~mm}$, while entrained voids are on average $50 \mu \mathrm{m}$ to $200 \mu \mathrm{m}$. Entrained voids are created on purpose to create the proper size and distribution of air voids. ASTM C457 states the ideal air-void content and the paste-air ratio for different aggregate sizes in concrete. These voids allow water from the capillary pores to move or expand when freezing or under pressure, without cracking the surrounding concrete.

\begin{tabular}{|c|c|c|}
\hline \multirow[t]{2}{*}{$\begin{array}{l}\text { Nominal or Observed } \\
\text { Maximum Size of Aggregate } \\
\text { in the Concrete, } \mathrm{mm} \text { [in.] }\end{array}$} & \multicolumn{2}{|c|}{$\begin{array}{c}\text { Total Area to be Traversed }{ }^{C} \text { for } \\
\text { Determination of } p,{ }^{D} A, \alpha \text {, or } \bar{L}, \text { min, } \mathrm{cm}^{2} \\
{\left[\text { in. }^{2}\right]} \\
\text { Based on Direct Measurement of: }\end{array}$} \\
\hline & $\begin{array}{c}\text { Total Air-Void } \\
\text { Content }\end{array}$ & Paste-Air Ratio, $p / A$ \\
\hline $150[6]$ & $1613[250]$ & $645[100]$ \\
\hline 75 [3] & 419 [65] & 194 [30] \\
\hline $37.5\left[11 \frac{1}{2}\right]$ & 155 [24] & $97[15]$ \\
\hline 25.0 [1] & 77 [12] & 77 [12] \\
\hline $19.0[3 / 4]$ & $71[11]$ & 71 [11] \\
\hline $12.5[1 / 2]$ & $65[10]$ & $65[10]$ \\
\hline $9.5[3 / 8]$ & $58[9]$ & $58[9]$ \\
\hline 4.75 (No. 4) & $45[7]$ & $45[7]$ \\
\hline
\end{tabular}

Table 2: Minimum Area of Finished Surface for Microscopical Measurement (ASTM C457)

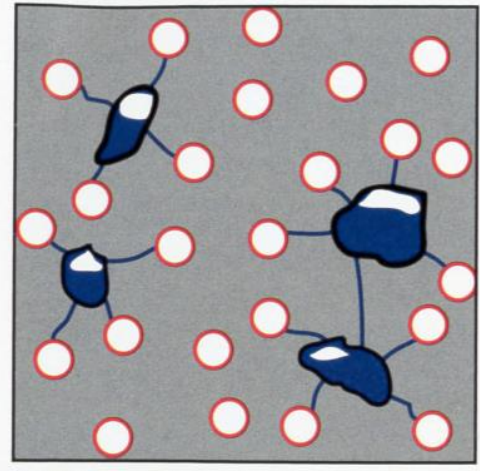

As temperatures drop, pores created by air entrainment allow the water a place to go as it freezes.

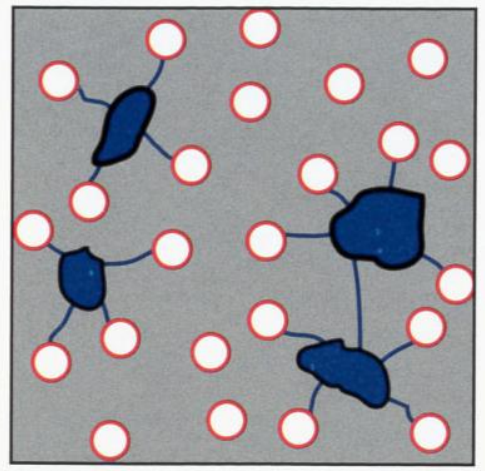

During freezing, water in the capillary pores expands; however, water is also going toward airentrained pores.

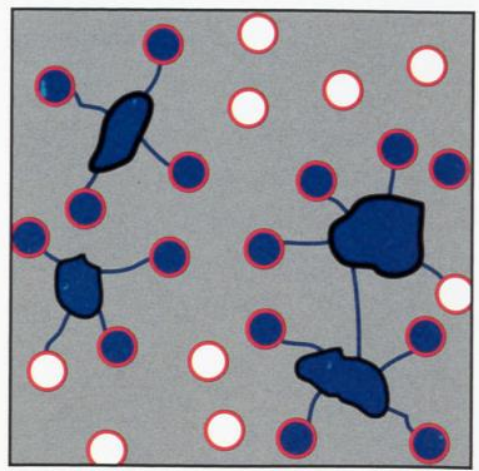

Under pressure, the water will be pushed into the air entrainment pores and not crack the concrete matrix.

Figure 1: Explanation of why we have entrainment pores. (Air Entrainment versus Air Entrapment, 2012) 
Air voids and thus porosity is affected by the water to cement ratio of a concretes mix. Due to the area needed to hold the water during the hydration process, the increase in water will increase the number of capillary pores. However, the water to cement ratio is not uniform throughout the concrete. Water films form around the large aggregate, creating more substantial amounts of capillary pores near the large aggregate.

As concrete goes through hydration, both capillary and gel pores will see a decrease in both volume and pore size, due to the formation of by-product created through the hydration process. To produce the optimal hydration during curing and to create the densest and thus strongest concrete, factors like temperature, time and moisture should be maintained. To keep additional pores from forming during the placement of concrete, fresh concrete should be compacted through rodding. This process will decrease the amount of water needed for hydration, which will create less capillary pores.

Admixtures are added to a concrete mixture for multiple reasons. Some admixtures like water reducers and water retarders aid in the placement of concrete. Water reducers lessen the amount of water needed, thus reducing the amount and size of capillary and gel pores found in the concrete. Water retarders will also decrease porosity, although smaller than that of water reducers.

Other admixtures include cementitious material replacements; these include slag, fly ash and silica fume. The testing and literature review done in this lab aims to figure out by how much do cementitious replacements effect the permeability of the mass concrete, looking at the porosity can indicate a predicted pattern. The theory is that due to the smaller size of the particles making up the cementitious material, voids within the mixture can be partially filled. Due to this, the porosity should be decreased with the admixture of cementitious material substitutes.

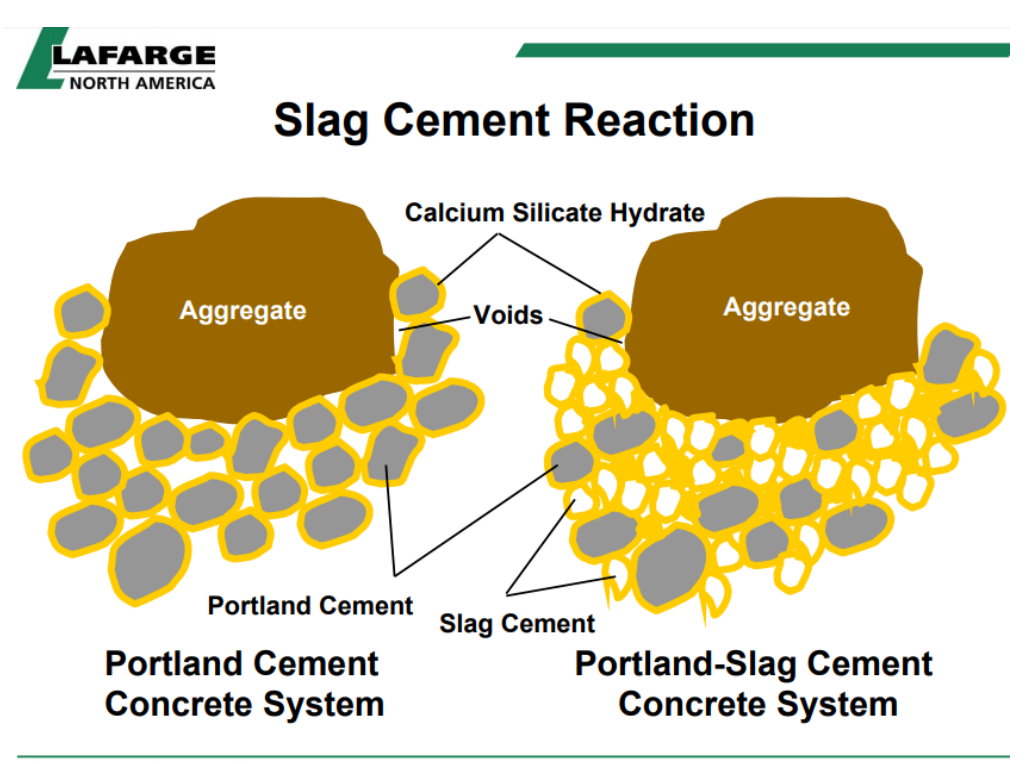

Figure 2: Representation of the benefit of using a partial slag replacement. (Lafarge at a Glance, 2015) 


\subsection{SLAG CONCRETE}

\subsubsection{HISTORY}

Slag is a by-product of the steel industry. It's created when metal is smelted from the raw ore. In the process of steel, slag is produced when molten steel is separated from the impurities of the steel-making furnaces. This process takes place when a lance is lowered into molten steel, and high-pressure oxygen is pumped into the steel, which combines with the impurities in the steel. These impurities can then be mixed with lime and dolomitic lime to form steel slag. There are different grades of steel slag produced, low, medium and high grade, each specifying a level of carbon found in the steel. The steel slag is mostly used for concrete; for this use, the slag must be left exposed to the elements for months so that it expands before it is used in concrete.

In many areas, slag is a by-product of the steel industry that can be easily accessible. In those areas, slag is an obvious substitution. It not only eliminates a harmful by-product but it also allows a cheaper alternative to cement, that not only makes the concrete less expensive but can also increase compressive strength long term. In areas in which slag is not easily accessible, it would need to be shipped in, which would make a slag substitution a more expensive alternative.

The use of slag to make concrete was first used in the 1700 's to make mortars. ${ }^{10}$ The firsttime slag concrete was used in the United States was in 1896, when it was used as part of the mix for ordinary Portland cement. ${ }^{10}$ It wasn't until 1980 before slag was considered a product in the United States, and was produced by Sparrows Point in Maryland. ${ }^{10}$

\subsubsection{DESIGN}

The mix design used to create the Slag specimens in this research contains a 50\% cementitious replacement.

\begin{tabular}{|c|c|c|}
\hline & Expected & Actual \\
\hline Water-cement Ratio & 0.40 & 0.422 \\
\hline Large Aggregate & \multicolumn{2}{|c|}{ \#57 Limestone } \\
\hline Cement & \multicolumn{2}{|c|}{$50 \%$} \\
\hline Slag & \multicolumn{2}{|c|}{$50 \%$} \\
\hline Fly Ash & \multicolumn{2}{|c|}{$0 \%$} \\
\hline Silica Fume & \multicolumn{2}{|c|}{$0 \%$} \\
\hline Air Content & $7 \%$ & $8 \%$ \\
\hline Slump & 7 in & 7.6 in \\
\hline
\end{tabular}

Table 3: Mix Design for Mass Concrete with 50\% Slag replacement. 


\subsubsection{HISTORY}

Typical concrete placement can leave voids and poorly settled concrete. Figure 3, demonstrates multiple examples of poorly placed concrete. A solution to this issue can be the placement of self-consolidating concrete, also known as self-compacting concrete. A mixture of SCC will flow easily and allow the concrete to fill all of the corners and spaces around rebar, eliminating many impurities and voids.

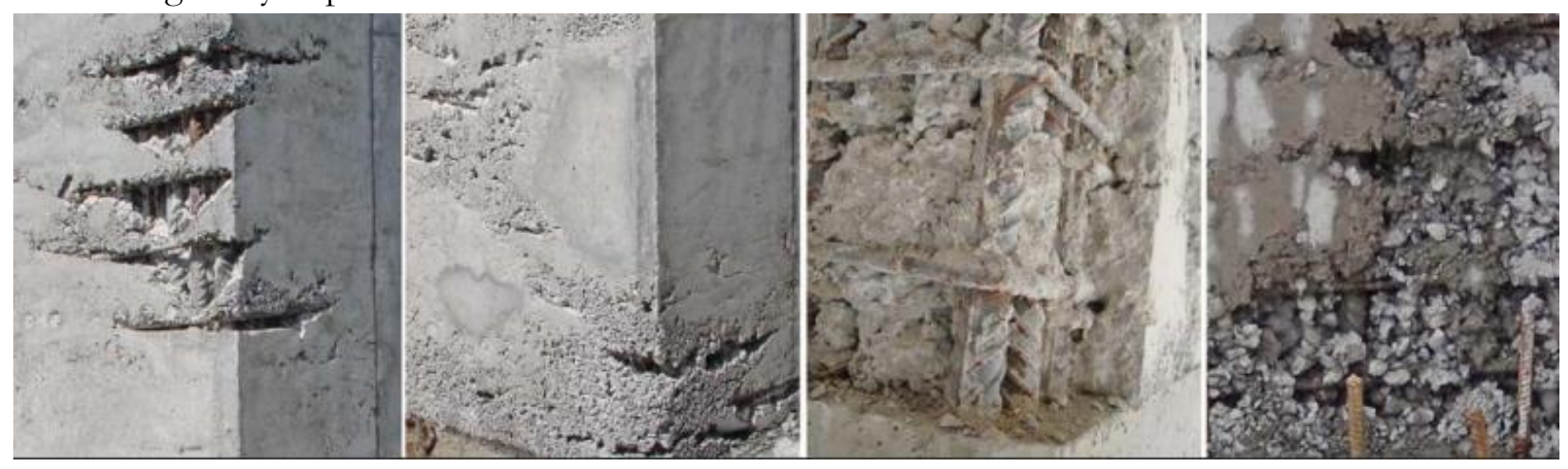

Figure 3: Disadvantages of ordinary concrete placement. ${ }^{13}$

SCC got its first start with the creation of underwater placement, in which concrete needed to be able to flow out and completely cover, a sometimes, unseen area. From the development of underwater tremmy mixes, paired with the largely noticed problem of deteriorating concrete structures, and new developments of chemical admixtures, a push for SCC was made. SCC was develioed by the University of Tokyo in Japan in $1988 .{ }^{34}$ The first standards were also developed in Japan during that time period, which was followed with a European developed standard in $2005 .{ }^{35}$

SCC was used in North America for almost exclusively reconstruction purposes until it became popular for precasting fabrication. This continued, and in 2007 the American Concrete Institute released a guideline on the process and testing of SCC, now also covered in the ASTM codes. ASTM codes show that SCC need not only the air testing of typical fresh concrete mixtures, but also the testing of a J-Ring and spreading testing, to show the flowability of the SCC.

Although SCC was originally untrusted by most people in the industry, it has come a long way. The initial belief was that a high slump was always a negative factor because it was an indicator of a high water-cement ratio or a low strength. Industry workers weren't sure how to test the strength of the SCC and were weary about how well it could withstand over time. These problems were paired with the high initial cost of production, to create an overall resistant industry. Due to a large amount of research, the development of codes, guidelines, and new testing methods, SCC has become increasing popular in recent years.

SCC can create possible economic savings, long term, because SCC takes less work to place and is also faster to place than traditional concrete which needs to be rodded and vibrated at 
different levels. SCC is also more aesthetically pleasing due to the smooth and less flawed surfaces created from the flowability. However, the largest advantage of SCC is its more consistent placement.

\subsubsection{DESIGN}

The mix design used to create the SCC specimens is described below.

\begin{tabular}{|c|c|c|}
\hline & Expected & Actual \\
\hline Water-cement Ratio & 0.351 & 0.35 \\
\hline Large Aggregate & \multicolumn{2}{|c|}{ \#67 Limestone } \\
\hline Cement & \multicolumn{2}{|c|}{$91 \%$} \\
\hline Slag & \multicolumn{2}{|c|}{$0 \%$} \\
\hline Fly Ash & \multicolumn{2}{|c|}{$9 \%$} \\
\hline Silica Fume & $5.50 \%$ & $8 \%$ \\
\hline Air Content & 21 inches & 29 inches \\
\hline Slump Spread &
\end{tabular}

Table 4: SCC Mix Design used in casting.

\subsection{ORDINARY PORTLAND CEMENT}

\subsubsection{HISTORY}

Ordinary Portland cement (OPC) is commonly referred to as concrete that has $100 \%$ of its cementitious material coming from Portland cement (PC). ASTM defines PC or cement as "a cement that sets and hardens by chemical reaction with water and is capable of doing so under water." 33

PC was first created in 1824 by Joseph Aspdin from natural cement in England. ${ }^{38}$ The name comes from the fact that the cement looks like Portland Stone, which was mined from the Island of Portland in England. ${ }^{38}$ Through the years, PC became more of what we know it to be today mostly due to the development of calcium silicates, which is needed to produce today's PC, and the rotary kiln, which allowed a more homogeneous mixture. The first regulations for OPC were produced by John Grant for use in 1859 for the London sewer project on the south side of the river Thames. ${ }^{39}$ PC was mostly imported into the United States until the late 19th century, in which the American made PC became comparable to the imported PC. ${ }^{40}$

In today's world, the two standards for PC are European \#N 197, used worldwide and ASTM C150, used in the USA. ASTM classifies PC into five categories, Type I, Type II, Type III, Type IV and Type V. Type I is known as general cement or common cement. Type II gives off slightly less heat during hydration and provides some defense against sulfate attack. Type III has a higher early strength but close to or lower strength at six-months. Type IV cement produces the 
lowest amount of heat during hydration which makes the strength of the concrete produced slower as well. Type V cement is developed to resist sulfate found in alkali soil and ground water.

\subsubsection{DESIGN}

Ordinary Portland cement is the base form of concrete. For this research, it is used as the controlled specimen to compare the replacement of slag at 50\% and the addition of SCC. The mixture used for OPC is described below.

\begin{tabular}{|c|c|c|}
\hline & Expected & Actual \\
\hline Water-cement Ratio & 0.42 & 0.409 \\
\hline Large Aggregate & \multicolumn{2}{|c|}{ \#57 Limestone } \\
\hline Cement & \multicolumn{2}{|c|}{$100 \%$} \\
\hline Slag & \multicolumn{2}{|c|}{$0 \%$} \\
\hline Fly Ash & \multicolumn{2}{|c|}{$0 \%$} \\
\hline Silica Fume & \multicolumn{2}{|c|}{$0 \%$} \\
\hline Air Content & \multicolumn{2}{|c|}{$7 \%$} \\
\hline Slump & 7 in \\
\hline
\end{tabular}

Table 5: OPC mix design used in this research.

\subsection{PREVIOUS RESEARCH}

\subsubsection{BILIR, TURHAN. "EFFECTS OF NON-GROUND SLAG AND BOTTOM ASH AS FINE AGGREGATE ON CONCRETE PERMEABILITY PROPERTIES.”}

When the cementitious material was replaced by slag $(\mathrm{S})$ at different ratios and then tested using RCPT, it showed a correlation between chloride permeability and percentage of slag. Shown in Figure 4, the optimal percentage of slag, for permeability, is approximately $25 \%$. When these results are compared with the ASTM C1202-97, "S-10" and "S-50" are in the Low chloride ion penetrability range and "S20-S40" are in the Very Low chloride ion penetrability range. Although a replacement of $50 \%$ slag was not the optimal replacement, it still falls within an acceptable range of chloride ion penetrability. 


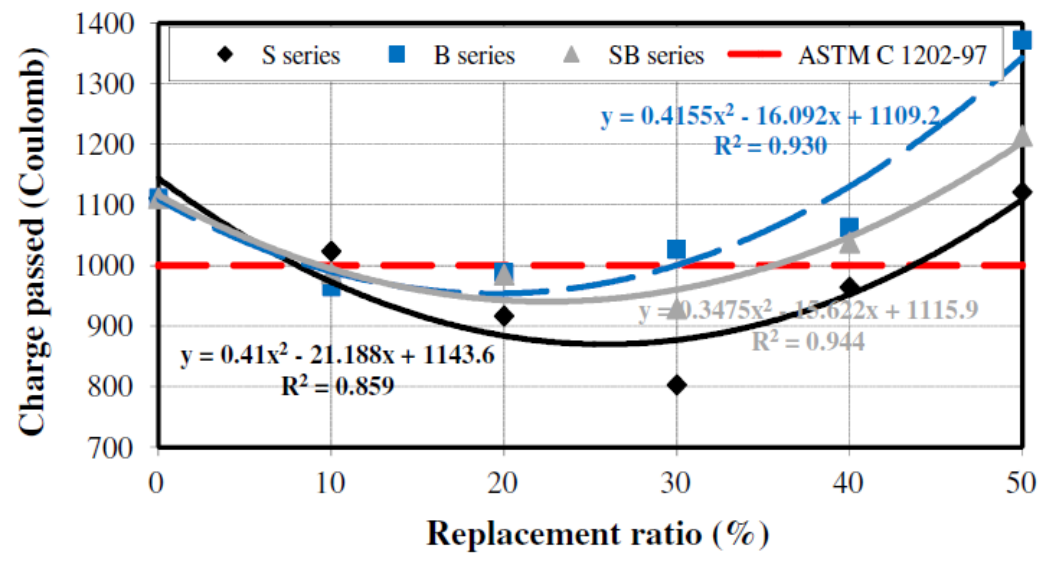

Figure 4 Results from the RCPT testing on different ratios of slag concrete, done by Turhan Bilir. S series stands for Slag, B series stands for Bottom ash and SB stands for Slag + Bottom ash, the water-cement ratio is 0.43. ${ }^{9}$

\begin{tabular}{ll}
\hline Charge Passed (coulombs) & Chloride Ion Penetrability \\
\hline$>4,000$ & High \\
$2,000-4,000$ & Moderate \\
$1,000-2,000$ & Low \\
$100-1,000$ & Very Low \\
$<100$ & Negligible \\
\hline
\end{tabular}

Table 6: Chloride Ion Penetrability Based on Charge Passed. ${ }^{3}$

\subsubsection{A STUDY OF THE BASIC ENGINEERING PROPERTIES OF SLAG CEMENT CONCRETE AND ITS RESISTANCE TO SEAWATER CORROSION W.- C. JAU AND D.-S. TSAY 1998}

Tsay's (1998) research looked at the effect slag substitution had on the permeability, strength, electrical resistance, concentration of chloride ions, corrosion potential and pore size distribution. The permeability was done by submerging samples in salt water for one year. The amount of slag replacement ranged from $0-50 \%$, the age of the concrete ranged from 1-12 months, and the water-cement ratio was $48 \%$ and $60 \%$. The results showed that a slag replacement of 20 $30 \%$ created the lowest amount of permeability. Concrete with a lower water-cement ratio was found to have lower permeability than the cement with a higher water-cement ratio. The younger concrete also had more electrical resistance and higher chloride concentration at the same depth when compared to the older concrete samples.

According to this research, the OPC concrete (0.48slag0) has a lower permeability rate than slag samples with $50 \%(0.48 \mathrm{slag} 50)$ replacement and $10 \%$ replacement $(0.48 \mathrm{slag} 10)$. However, when slag is replaced with only $20 \%(0.48 \mathrm{slag} 20)$ and $30 \%$ (0.48slag 30$)$, OPC had a higher permeability rate. 


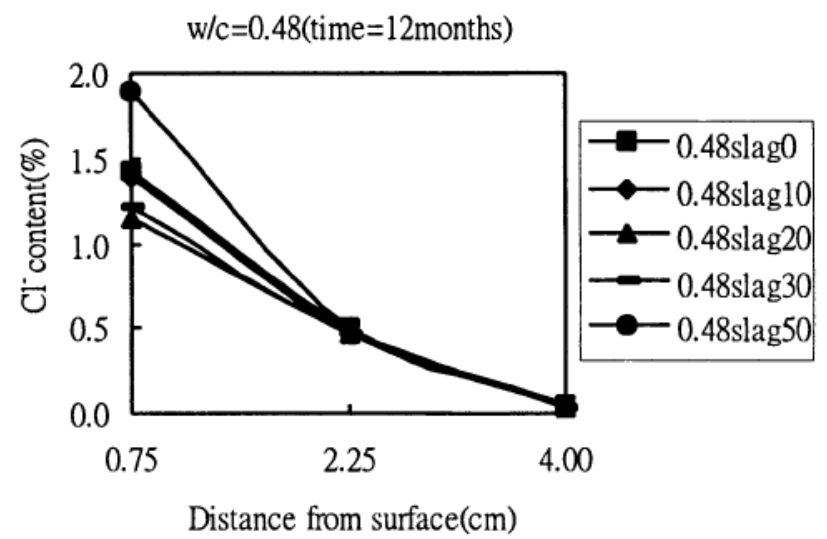

Figure 5: Results from W.-C. Jau1 and D.-D. Tsay's research. (Tsay 1998) .

\subsubsection{THE PORE STRUCTURE OF CEMENT PASTE BLENDED WITH FLY ASH ZHUQING YU*, GUANGE YE, 2013}

The addition of fly ash to concrete increased the amount of porosity in concrete samples, thus increasing the permeability. Zhuqing Yu's study used Mercury Intrusion Porosimetry (MIP), Nitrogen Sorption/Desorption (NSD), Helium and Methanol Pycnometry to determine the porosity of different samples. The samples had water-cement ratios of 0.4 and 0.5 . The percentage of fly ash included 0,30 and 50\% substitution. The time between casting and testing ranged from 1 to 730 days.

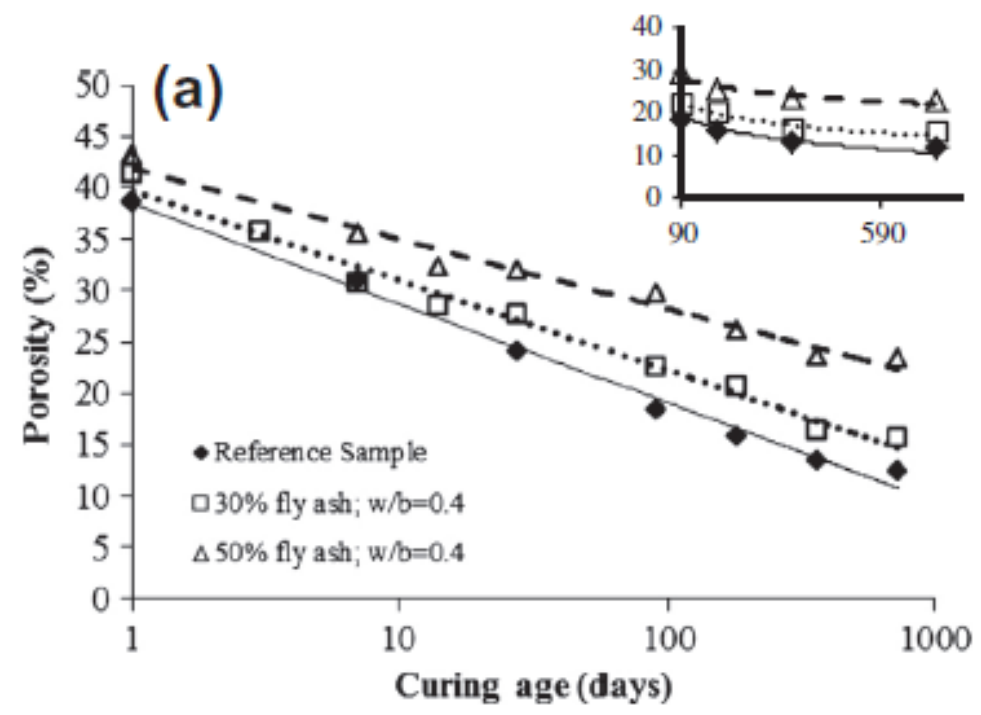

Figure 6: The relationship of curing time to porosity for different amounts of fly ash. ${ }^{15}$

The results show that for all ages, water-cement ratios and percentage of fly ash replacement, the porosity is always higher with higher fly ash replacement. 


\begin{tabular}{lccc}
\hline \multirow{2}{*}{ Curing age (Years) } & \multicolumn{2}{l}{ Total porosity (\%) } \\
\cline { 2 - 4 } & 5 Years & 10 Years & 50 Years \\
\hline Reference sample & 6.91 & 4.00 & - \\
$30 \%$ fly ash; w/b $=0.4$ & 11.15 & 8.51 & 2.38 \\
$50 \%$ fly ash; w/b $=0.4$ & 19.62 & 17.57 & 12.82 \\
$30 \%$ fly ash; w/b $=0.5$ & 14.27 & 10.98 & 3.33 \\
\hline
\end{tabular}

Table 7: Porosity percentages of different fly ash samples. ${ }^{15}$

\subsubsection{SERVICE LIFE PREDICTION: THEORECRETE, LABCRETE AND} REALCRETE APPROCHES, ROBERTO J. TORRENT, 2013

This paper looked at the various methods of determining the service life of concrete. The first method examined in this paper was the modelling through Fick's Law. Although these equations can be debated on the accuracy, many models start with Fick's second law.

$$
\begin{aligned}
& \mathrm{T}_{\mathrm{i}}=\frac{\mathrm{c}^{2}}{4 \cdot\left[\mathrm{D}_{0}\left(\mathrm{t}_{0} / \mathrm{t}\right)^{\mathrm{m}}\right]} \mathrm{A}^{2} \\
& \mathrm{~A}=\frac{1}{\operatorname{erf}^{-1}\left[1-\left(\mathrm{C}_{\mathrm{er}} / \mathrm{C}_{\mathrm{s}}\right)\right]}
\end{aligned}
$$

where

$\mathrm{T}_{\mathrm{i}} \quad=$ time for initiation of corrosion (years)

c = cover depth $(\mathrm{mm})$

$\mathrm{D}_{0} \quad=$ coefficient of chloride diffusion considered/measured at age $\mathrm{t}_{0}$ (typically 28 days)

$\mathrm{t} \quad=$ hydration time $\left(\mathrm{t} \leq \mathrm{t}_{\max }, \mathrm{t}_{\max }\right.$ corresponding to the end of hydration)

$\mathrm{m} \quad$ = "ageing exponent" or "diffusion decay exponent"

$\operatorname{erf}^{-1}=$ inverse error function

$\mathrm{C}_{\mathrm{cr}}=$ critical concentration of chlorides, capable of initiating the corrosion process

$\mathrm{C}_{\mathrm{s}} \quad=$ concentration of chlorides at the surface of the element

Equation 3: Fick's 2nd law solution to calculate the service life. (Torrent, 2013)

The next method examined was the Theorecrete, or SLP, method. This model used the water-cement ratio as well as the amount of cementitious material to determine the service life of concrete. This method, however, has a significant flaw in the parameter of the amount of cement. When cementitious substitution is involved in a mix design the amount of cement or $\mathrm{C}$ parameter becomes very unclear. This ambiguity is seen in the results created by using this method. 


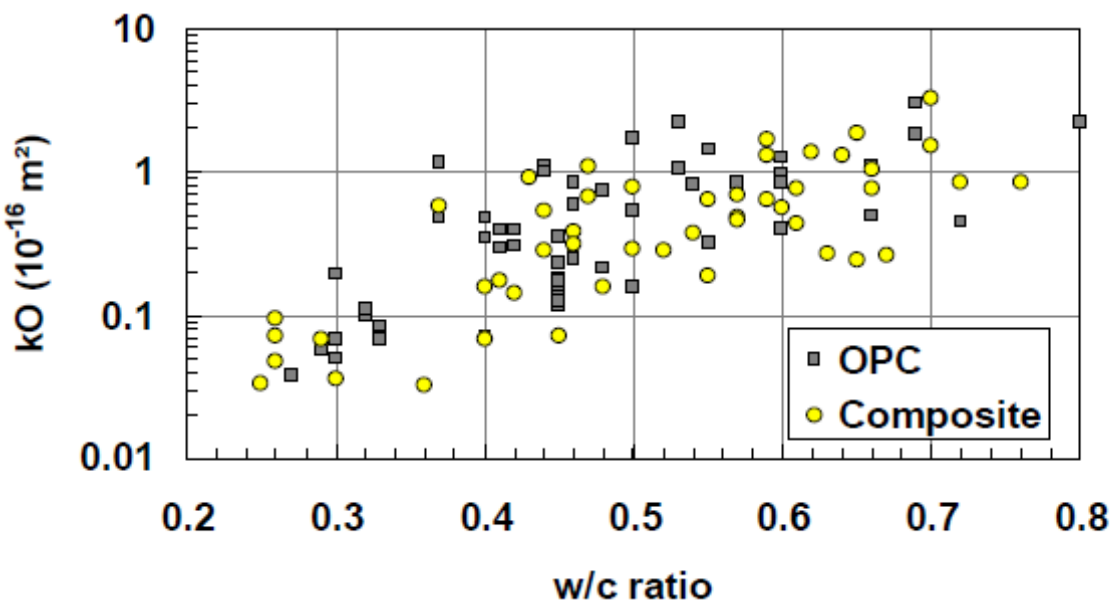

Figure 7: Effect of cement characteristics and water-cement ratio on the K. parameter used in service life predictions. (Torrent, 2013)

Due to this predicament, a $\mathrm{K}$ value was added to account for the variations in cementitious admixtures.

The next method observed in this paper is the Life-365 Theorecrete method. This model uses the same starting equation from Fick's law but uses a new comparison to obtain the D function.

$$
\mathrm{D}_{28 \mathrm{~d}}\left(\mathrm{~m}^{2} / \mathrm{s}\right)=10^{(-12.06+2.4 \cdot \mathrm{w} / \mathrm{c})}
$$

Equation 4: Life-365 model's proposed D function. ${ }^{28}$

This method is more conservative than the original Theorecrete method but still doesn't consider other variables or the possible variability between the desired water-cement ratio and the actual water-cement ratio of placed concrete.

A Labcrete method was observed that took the same beginning equation but produced the $\mathrm{D}$ function from test results of chloride penetration testing. These predictions become more accurate due to the consideration of corrosion, curing, and cover thickness factors that have been added to the original equation. This model is more accurate than the Theoretical models but still uses a theoretical cover thickness and uses a $\mathrm{D}$ function within a power law which is not proven to be exact.

The last type of method reviewed in this paper is the Realcrete methods. These methods consider not only the characteristics found in the Labcrete method, but they also emphasize the importance of onsite non-destructive testing and measurements of the actual cover depth. This model creates a $\mathrm{D}$ function that relates to the coulomb value found in penetrability equations. This relationship can be used directly with RCPT test results, to see the service life of a concrete sample. 


$$
\mathrm{D}_{\mathrm{Cl}}\left(10^{-12} \mathrm{~m}^{2} / \mathrm{s}\right)=0.4+0.002 . \text { Coulomb }
$$

Equation 5: D function created in the Realcrete methods. ${ }^{28}$

\subsubsection{ENHANCING THE SERVICE LIFE OF CONCRETE EXPOSED TO CHLORIDE ATTACK, ZHENGTIAN SONG, 2014}

Zhengtian Song's dissertation looks at not only the effect cementitious supplementation has on porosity and permeability but also its impact on the service life of concrete. Song looked at and categorized the different methods to determine service life into two categories. The first category was Error Function Models with Constant D and Cs (ERFC), these models are the most common and traditional methods. The second category is Numerical models, which also consider the binding effect of chloride and the chloride contaminated or maintenance concrete structure. Table 8 is the compiled comparison of the different model's characteristics.

\begin{tabular}{|c|c|c|c|c|c|c|c|c|}
\hline \multirow[t]{2}{*}{ Model Type } & \multicolumn{2}{|c|}{$\begin{array}{l}\text { Chloride } \\
\text { Diffusion } \\
\text { Coefficient }\end{array}$} & \multicolumn{2}{|c|}{$\begin{array}{l}\text { Surface } \\
\text { Chloride } \\
\text { Content }\end{array}$} & \multirow[t]{2}{*}{$\begin{array}{l}\text { Chloride } \\
\text { Binding } \\
\text { Capacity }\end{array}$} & \multicolumn{2}{|c|}{$\begin{array}{l}\text { Concrete } \\
\text { Structure }\end{array}$} & \multirow[t]{2}{*}{ References } \\
\hline & $\mathrm{D}$ & $\mathrm{D}(\mathrm{t})$ & $\mathrm{C}_{\mathrm{S}}$ & $\mathrm{C}_{\mathrm{S}}(\mathrm{t})$ & & New & Old & \\
\hline \multirow{6}{*}{ ERFC } & $\sqrt{ }$ & $\times$ & $\sqrt{ }$ & $\times$ & $\times$ & $\sqrt{ }$ & $\times$ & Collepardi et al., (1972) \\
\hline & $\sqrt{ }$ & $\sqrt{ }$ & $\sqrt{ }$ & $\times$ & $\times$ & $\sqrt{ }$ & $x$ & Takewaka and Matsumoto, (1988) \\
\hline & $\sqrt{ }$ & $\sqrt{ }$ & $\sqrt{ }$ & $\times$ & $x$ & $\sqrt{ }$ & $x$ & Tang and Lars-olof, (1992) \\
\hline & $\sqrt{ }$ & $\sqrt{ }$ & $\sqrt{ }$ & $\times$ & $\times$ & $\sqrt{ }$ & $\times$ & Maage et al., (1995) \\
\hline & $\sqrt{ }$ & $\sqrt{ }$ & $\sqrt{ }$ & $\sqrt{ }$ & $\times$ & $\sqrt{ }$ & $x$ & Lars-olof, (2000) \\
\hline & $\sqrt{ }$ & $\sqrt{ }$ & $\sqrt{ }$ & $\times$ & $\times$ & $\sqrt{ }$ & $\times$ & Tang and Gulikers, (2007) \\
\hline$\Psi_{p}^{\prime}$ & $\sqrt{ }$ & $\sqrt{ }$ & $\sqrt{ }$ & $\sqrt{ }$ & $\times$ & $\sqrt{ }$ & $\times$ & Mejlbro and Poulsen, (1996) \\
\hline \multirow{5}{*}{ Numerical } & $\sqrt{ }$ & $\sqrt{ }$ & $\sqrt{ }$ & $\sqrt{ }$ & $\times$ & $\sqrt{ }$ & $x$ & Bentz and Thomas, (1999) \\
\hline & $\sqrt{ }$ & $\sqrt{ }$ & $\sqrt{ }$ & $\sqrt{ }$ & $\sqrt{ }$ & $\sqrt{ }$ & $\times$ & Martin-Perez et al., (2000) \\
\hline & $\sqrt{ }$ & $\sqrt{ }$ & $\sqrt{ }$ & $\sqrt{ }$ & $\times$ & $\sqrt{ }$ & $\times$ & Petre-Lazar,(2000) \\
\hline & $\sqrt{ }$ & $\sqrt{ }$ & $\sqrt{ }$ & $\sqrt{ }$ & $\times$ & $\sqrt{ }$ & $x$ & Bamforth, (2004) \\
\hline & $\sqrt{ }$ & $\sqrt{ }$ & $\sqrt{ }$ & $\sqrt{ }$ & $\times$ & $\sqrt{ }$ & $\sqrt{ }$ & [Selected Model] \\
\hline Probabilistic & $\sqrt{ }$ & $\sqrt{ }$ & $\sqrt{ }$ & $\times$ & $\times$ & $\sqrt{ }$ & $\times$ & FIB, (2006) \\
\hline
\end{tabular}

Table 8: Description of different service life prediction models (Song, 2014) ${ }^{29}$

After comparing the different models, Song chose to focus on the Numerical models because they looked at multiple factors, due to this many parameters needed to be selected. The input parameters are the apparent diffusion coefficient (Da), surface chloride concentration (Cs), the aging factor (n) and the critical chloride threshold level (Ccrit). Da describes the ability of chloride ion penetrating through concrete. This parameter comes from the nonlinear regression analysis method and creates a constant value from the chloride content profile observed from testing. Cs is a time-dependent parameter that shows the speed in which the chloride content is applied to the concrete. Three different Cs graphs have been created to cover the application of chloride. Cs-1 has 
the full Cs applied instantly, Cs-2 and Cs-3 have a linear increase of Cs over time of (tmax). The difference between Cs-2 and Cs-3 is the slope of the linear rise of Cs which allows for a differing time frame, Cs-2 being a ten-year increase and Cs-3 being a twenty-year increase. Ccrit is the amount of chloride at the time that the steel inside of concrete has become corroded. This value should be used in the time depended function of $\mathrm{C}$ to find the service life of concrete. The last parameter in a numerical model is the $\mathrm{n}$ parameter which covers the aging factor of the concrete. These parameters and their effect on service life are organized in the following table.

$$
D a=D a(t) \cdot \frac{1}{1-n} \cdot\left[\left(1+\frac{t_{\alpha \alpha}}{t}\right)^{1-n}-\left(\frac{t_{\alpha x}}{t}\right)^{1-n}\right]
$$

Equation 6: Equation to determine the Da parameter. ${ }^{29}$

$$
C(x, t)=C_{s}\left(t_{e x}, t\right) \cdot \Psi_{P}\left(\frac{x}{2 \sqrt{D(t) \cdot t}}\right)
$$

Equation 7: Equation used to determine the service life. ${ }^{29}$

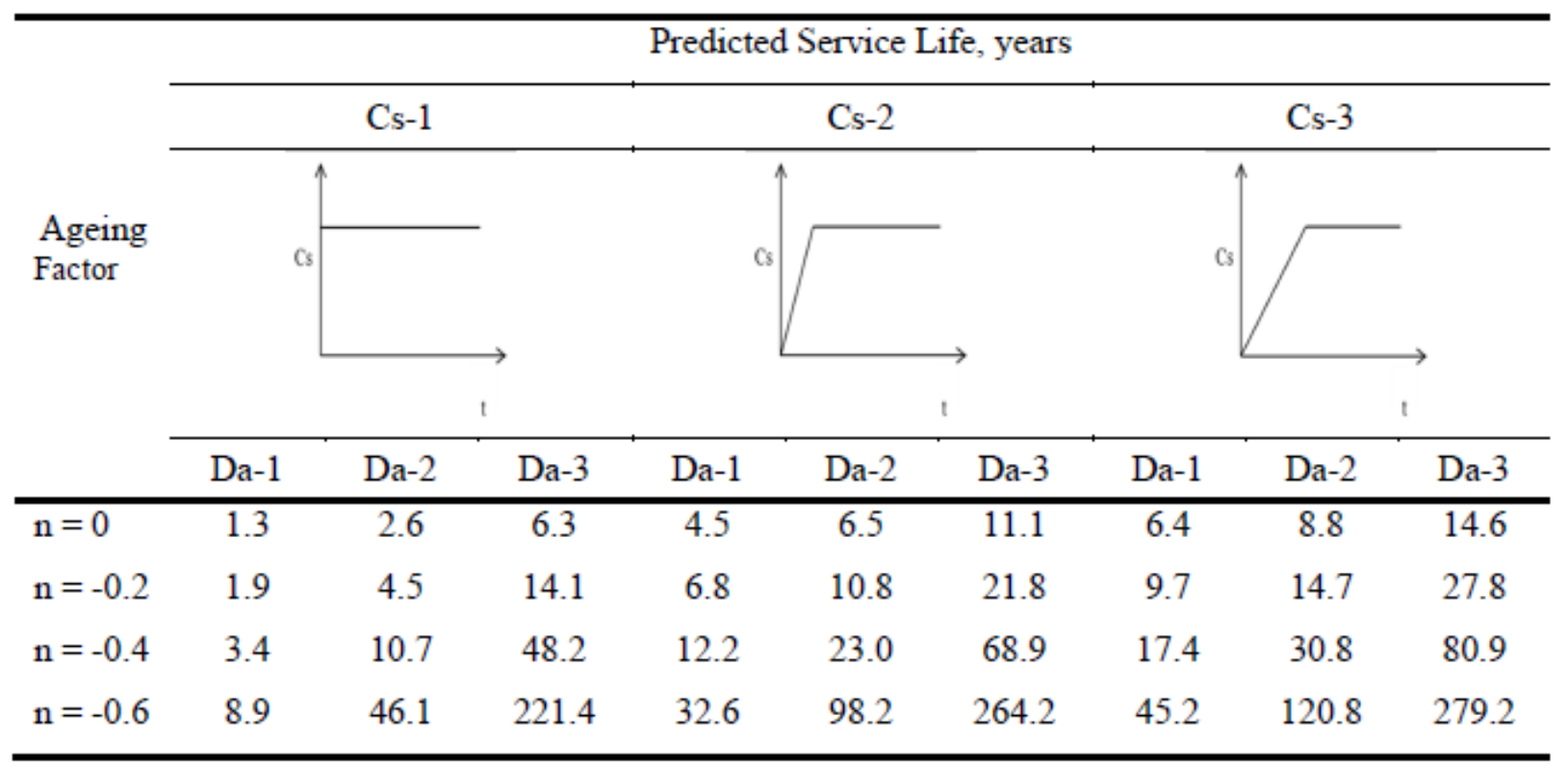

Table 9: Predicted influence on service life of concrete in the numerical model, based off the Cs, $n$ and Da parameters. (Song, 2014)

This dissertation covered the penetration of chloride in concrete using four different methods. Method A is the Rapid Chloride Penetration Testing, method B used Rapid Chloride Migration Testing, Method C used Multi-Regime Testing, the last process, method D used Natural 
Diffusion Cell testing. The testing's looked at multiple water-cement ratios, and mixes of cementitious material., all results are shown in the following table.

\begin{tabular}{|c|c|c|c|c|c|c|}
\hline \multirow{5}{*}{$\begin{array}{l}\text { Combination } \\
\text { Type, } \%\end{array}$} & \multirow{2}{*}{$\begin{array}{c}\text { Method A } \\
\text { Charge } \\
\text { Passed } \\
\end{array}$} & \multirow{2}{*}{\multicolumn{2}{|c|}{$\begin{array}{c}\text { Method B } \\
\text { Non-steady State } \\
\text { Migration } \\
\text { Coefficient } \\
\end{array}$}} & \multicolumn{2}{|c|}{ Method C } & \multirow{2}{*}{$\begin{array}{c}\text { Method D } \\
\text { Steady State } \\
\text { Migration } \\
\text { Coefficient }\end{array}$} \\
\hline & & & & \multicolumn{2}{|c|}{$\begin{array}{c}\text { Non-steady State } \\
\text { Diffusion Coefficient }\end{array}$} & \\
\hline & $\begin{array}{c}\text { Coulombs } \\
\end{array}$ & \multicolumn{2}{|c|}{$\mathrm{Da}, 10^{-12} \mathrm{~m}^{2} / \mathrm{s}$} & $\mathrm{Da}, 10^{-12} \mathrm{~m}^{2} / \mathrm{s}$ & $\mathrm{C}_{5}, \%$ & $\mathrm{Da}, 10^{-12} \mathrm{~m}^{2 / s}$ \\
\hline & & \multicolumn{4}{|c|}{ Test Age, Days } & \\
\hline & $28 \quad 120$ & 28 & 120 & \multicolumn{2}{|l|}{90} & Vary (days) \\
\hline \multicolumn{7}{|c|}{$0.35 \mathrm{w} / \mathrm{c}$ ratio } \\
\hline $100 \mathrm{PC}$ & 23002000 & 7.2 & 5.8 & 6.0 & 0.3 & - \\
\hline $70 \mathrm{PC} 30 \mathrm{FA}$ & 2025350 & 7.6 & 1.5 & 1.1 & 0.4 & $6.6(34)$ \\
\hline 50PC50GGBS & $600 \quad 470$ & 2.4 & 2.3 & 0.8 & 0.5 & $1.6(32)$ \\
\hline 30FAl0LS & 2550600 & 8.0 & 2.6 & 1.1 & 0.4 & $3.4(109)$ \\
\hline 50GGBS10LS & $510 \quad 370$ & 1.9 & 1.8 & 0.8 & 0.5 & $2.9(49)$ \\
\hline 30FAl0SF & $750 \quad 340$ & 2.4 & 1.3 & 1.9 & 0.4 & $1.8(158)$ \\
\hline 30FAl5MK & $560 \quad 245$ & 4.2 & 2.3 & 1.4 & 0.6 & $2.7(151)$ \\
\hline $30 \mathrm{FAl} 5 \mathrm{MK}^{*}$ & $950 \quad 350$ & 4.5 & 2.0 & 1.7 & 0.4 & $2.6(146)$ \\
\hline \multicolumn{7}{|c|}{$0.40 \mathrm{w} / \mathrm{c}$ ratio } \\
\hline $100 \mathrm{PC}$ & 28002400 & 8.1 & 7.0 & 8.2 & 0.3 & - \\
\hline $70 \mathrm{PC} 30 \mathrm{FA}$ & 2925575 & 10.5 & 1.9 & 1.2 & 0.4 & $8.9(34)$ \\
\hline 50PC50GGBS & $685 \quad 530$ & 2.7 & 2.6 & 1.0 & 0.5 & $3.5(32)$ \\
\hline 30FAl0LS & 2850750 & 10.7 & 3.1 & 1.5 & 0.5 & $4.0(109)$ \\
\hline 50GGBS10LS & $540 \quad 530$ & 1.9 & 2.1 & 1.0 & 0.5 & $3.7(49)$ \\
\hline 30FAl0SF & $975 \quad 350$ & - & - & 1.8 & 0.4 & $2.2(158)$ \\
\hline 30FAl5MK & 800350 & 4.5 & 2.9 & 1.7 & 0.5 & $3.4(151)$ \\
\hline $30 \mathrm{FAl} 5 \mathrm{MK}^{*}$ & 1050375 & 4.6 & 2.5 & 1.8 & 0.4 & $3.2(146)$ \\
\hline \multicolumn{7}{|c|}{$0.45 \mathrm{w} / \mathrm{c}$ ratio } \\
\hline $100 \mathrm{PC}$ & 34752900 & 9.6 & 9.1 & 10.2 & 0.3 & - \\
\hline $70 \mathrm{PC} 30 \mathrm{FA}$ & 46401050 & 12.7 & 2.5 & 2.1 & 0.4 & $12.3(34)$ \\
\hline 50PC50GGBS & 1060755 & 3.3 & 3.1 & 1.8 & 0.5 & $7.0(32)$ \\
\hline 30FAl0LS & 3550775 & 11.0 & 3.8 & 2.2 & 0.5 & $4.9(109)$ \\
\hline 50GGBS10LS & 560550 & 2.6 & 2.6 & 1.4 & 0.5 & $4.5(49)$ \\
\hline 30FAl0SF & 1090370 & 2.9 & 2.0 & 1.9 & 0.4 & $2.7(158)$ \\
\hline $30 \mathrm{FAl} 5 \mathrm{MK}^{4}$ & $980 \quad 375$ & 4.9 & 3.7 & 2.2 & 0.5 & $4.1(151)$ \\
\hline $30 \mathrm{FAl} 5 \mathrm{MK} *$ & 1240545 & 5.1 & 3.0 & 1.9 & 0.4 & $3.9(146)$ \\
\hline
\end{tabular}

" $15 \%$ addition of $\mathrm{MK} ;$ * $15 \%$ replacement of PC by ME

Table 10: Chloride ingress measurements of concrete (cement content of $\left.400 \mathrm{~kg} / \mathrm{m}^{\wedge} 3\right){ }^{29}$

3.6.6 A VIRTUAL RAPID CHLORIDE PERMEABILITY TEST, DALE P. BENTZ 2007

Bentz research created a virtual instant Rapid Chloride Penetration testing (RCPT). His method uses algorithms to produce the percentage of the three most essential ions, potassium, 
sodium, and hydroxide. The virtual results also use an equation that uses the water-cement ratio to produce the $\log 10 \mathrm{D}$ function which in this case is the diffusivity of the ionic species in the concrete.

$$
\begin{aligned}
\log _{10}\left(D_{\text {specimen }}\right)= & \left(-13.75-0.82 \frac{w}{c}+32.55\left(\frac{w}{c}\right)^{2}\right. \\
& +8.374 \mathrm{CSF}+15.36(\mathrm{CSF})^{2} \\
& +23.15\left(\frac{w}{c}\right) \mathrm{CSF}+5.79 \alpha-21.1\left(\frac{w}{c}\right) \alpha \\
& \left.-43.15(\mathrm{CSF}) \alpha-1.705 V_{\mathrm{agg}}\right) .
\end{aligned}
$$

Equation 8: Bentz equation for the log10(D) function. (Bentz, 2007) ${ }^{30}$

\begin{tabular}{|c|c|c|c|c|c|c|c|}
\hline Sample & $\begin{array}{l}\text { Mixture } \\
\text { proportions }\end{array}$ & $\begin{array}{l}\text { Age } \\
\text { (d) }\end{array}$ & $\begin{array}{l}\text { Measured } \\
\text { charge passed } \\
\text { (C) }\end{array}$ & $\begin{array}{l}\text { Predicted } \\
\text { charge passed } \\
\text { (C) }\end{array}$ & $\begin{array}{l}\text { Estimated } \\
\sigma_{\text {poresoln }}(\mathrm{S} / \mathrm{m})\end{array}$ & $\begin{array}{l}\text { Assumed degree of } \\
\text { hydration of binder }\end{array}$ & $\begin{array}{l}\text { Predicted final } \\
\text { temperature }\left({ }^{\circ} \mathrm{C}\right)\end{array}$ \\
\hline $\begin{array}{l}\text { Shotcrete type I cem } 7 \% \\
\text { fume (accelerator) }\end{array}$ & $1: 3.8: 0.8: 0.44^{\mathrm{a}}$ & 150 & 1815 & 2030 & 9.6 & 0.72 & 35.0 \\
\hline $\begin{array}{l}\text { Shotcrete type I cem } 7 \% \\
\text { fume }\end{array}$ & $1: 3.8: 0.8: 0.44$ & 150 & 1964 & 2030 & 9.6 & 0.72 & 35.0 \\
\hline Concrete type V cem & $1: 2.0: 3.0: 0.4$ & 3 & 5378 & 5613 & 20.5 & 0.62 & 56.1 \\
\hline Concrete type V cem & $1: 2.0: 3.0: 0.4$ & 28 & 2598 & 2815 & 21.6 & 0.72 & 39.6 \\
\hline Concrete type I cem & $1: 2.0: 3.0: 0.5$ & 7 & 9682 & 9961 & 10.6 & 0.85 & 70.8 \\
\hline Concrete type I cem & $1: 2.0: 3.0: 0.5$ & 56 & 5953 & 6002 & 10.8 & 0.89 & 58.5 \\
\hline Concrete type I cem & $1: 2.0: 3.0: 0.5$ & 196 & 4328 & 3974 & 10.9 & 0.92 & 46.5 \\
\hline Concrete type I cem & $1: 2.0: 3.0: 0.5$ & 476 & 1569 & 1705 & 11.3 & 0.99 & 33.1 \\
\hline $\begin{array}{l}\text { Concrete type I cem } 58 \% \\
\text { fly ash }\end{array}$ & $1: 2.0: 3.0: 0.32$ & 28 & 663 & 608 & 35.8 & 0.58 & 26.6 \\
\hline $\begin{array}{l}\text { Concrete type I cem } 45 \% \\
\text { slag 3\% fume }\end{array}$ & $1: 2.0: 3.0: 0.4$ & 3 & 3552 & 3659 & 6.1 & 0.51 & 44.6 \\
\hline $\begin{array}{l}\text { Concrete type I cem } 45 \% \\
\text { slag 3\% fume }\end{array}$ & $1: 2.0: 3.0: 0.4$ & 28 & 522 & 556 & 6.8 & 0.7 & 26.3 \\
\hline $\begin{array}{l}\text { Concrete type I cem } 65 \% \\
\text { slag 3\% fume }\end{array}$ & $1: 2.0: 3.0: 0.4$ & 3 & 4405 & 2257 & 4.0 & 0.51 & 36.3 \\
\hline $\begin{array}{l}\text { Concrete type I cem } 65 \% \\
\text { slag 3\% fume }\end{array}$ & $1: 2.0: 3.0: 0.4$ & 28 & 356 & 359 & 4.4 & 0.7 & 25.1 \\
\hline $\begin{array}{l}\text { Type I cem } 75 \% \text { slag 3\% } \\
\text { fume }\end{array}$ & $1: 2.0: 3.0: 0.4$ & 3 & 3013 & 1527 & 2.8 & 0.51 & 32.0 \\
\hline $\begin{array}{l}\text { Type I cem } 75 \% \text { slag 3\% } \\
\text { fume }\end{array}$ & $1: 2.0: 3.0: 0.4$ & 28 & 262 & 253 & 3.1 & 0.7 & 24.5 \\
\hline
\end{tabular}

Equation 8 was developed and should be used for water-cement ratios of $0.3-0.5$, a silica fume replacement of 0.1 or less, an aggregate volume fraction ranging from $0.62-0.70$ and a degree of hydration between 0.6 and 0.93 .

Table 11: Comparison between predicted and experiment permeability of different concrete designs. (Bentz, 2007)

These results indicate that the virtual RCPT program should show reasonable estimation of RCPT based off the mix designs discussed in this research. 


\subsubsection{MODELS FOR CHLORIDE INGRESS INTO CONCRETE- FROM}

\section{COLLEPARDI TO TODAY, LARS-OLOF NILSSON 2009}

Nilsson's article looks at the development of the prediction model starting with Collepardi's model from 1970 and ending with a current model of penetrability. Collepardi's model looked at an error function solution to Fick's law to predict the penetrability of chloride ions. This model was widely used for years until it was noticed that the diffusion coefficient $\mathrm{D}$ was not a constant variable, but instead, a time-dependent variable, introducing the need for the $\mathrm{D}(\mathrm{t})$ function. This function has been debated, and many versions of its calculation have been proposed.

Fundamentally, there are two types of models, the first being empirical which are modeled around data and Fick's 2nd law. These models are not able to be adjusted for new mix designs and new situations, but must instead be reintroduced to include unique situations. This problem is because empirical models make many assumptions that are not universal amongst all concrete samples. The other type of model is a physical model which accounts for many parameters, using a flux equation, which makes it adjustable to new designs and situation. Physical models require many input values from the material's characteristics as well as environmental characteristics. These equations can be more challenging to complete but are useful in validating new empirical calculations. 


\section{CHAPTER 4: EXPERIMENTATION}

\subsection{CONCRETE PREPARATION}

\subsubsection{RODING}

Following the ASTM C 192/C 192M - 02 rodding is done for cylinder specimens at each level of concrete placement. Rodding is a process done by inserting a metal pole with a rounded end into a freshly placed layer of concrete. Rodding is done multiple times, and the pattern should cover the cylinder evenly, usually achieved by going in a circular pattern. Some procedures specify the number of times each layer should be rodded, but twenty-five times per segment, is a standard number. After a layer is finished being rodded, the mold should be tapped ten to fifteen times with a rubber mallet. This standard is used for placing all concrete mixtures except for any selfconsolidating concrete mixtures. The other exception to rodding is when vibrating can be used as a substitute.

\subsubsection{AIR CONTENT}

Per ASTM C231/C231M-17a all batches of concrete were tested for their air content. In preparation for the testing, an air measuring set-up will be needed. These set-ups work with Boyles laws to create a pressure reading of the chamber. The apparatus should consist of a cylindrical sixliter measuring bowl, and a top consisting of a pressure gauge, a pump, and petcocks, that can be latched on.

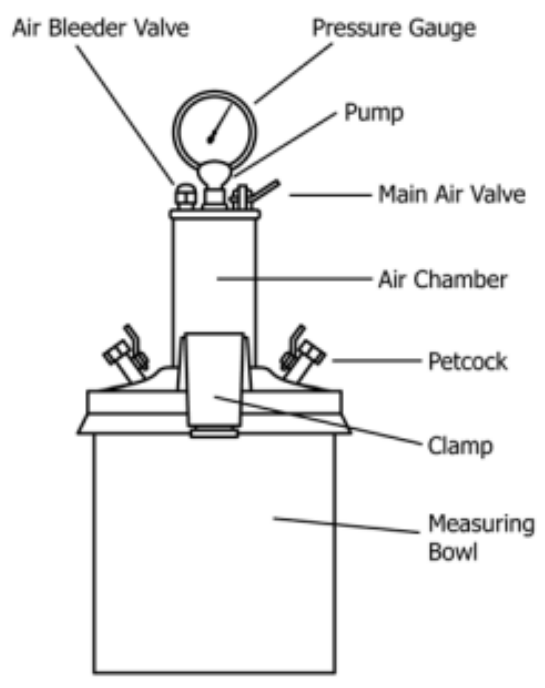

Figure 8: Vertical Pressure Chamber for determining air content of freshly mixed concrete. ${ }^{16}$

To start the test the apparatuses pictured above is rinsed off, and the measuring bowl is filled one-third of the way with freshly mixed concrete, rodded twenty-five times and tapped. The second and third layer is added and rodded in a similar way, with the only difference being that the later 
layers are rodded through their layer and one inch into the layer below them. The top of the measuring bowl is leveled, and the rim of the bowl cleaned. The lid is then fastened on top of the bowl, and the petcocks are opened. Water is added to one side through a water bottle inserted into a petcock, and the water is added until it starts to come out of the other side. At that point, both petcocks are closed, and the pump is used until the air gauge passes the desired pressure. Give the side of the measuring bowl a sharp hit with the tapping mallet, then open the petcocks and give the measuring bowl one more hit. The pressure gauge should make a jump, and the final reading will be the air content of the sample.

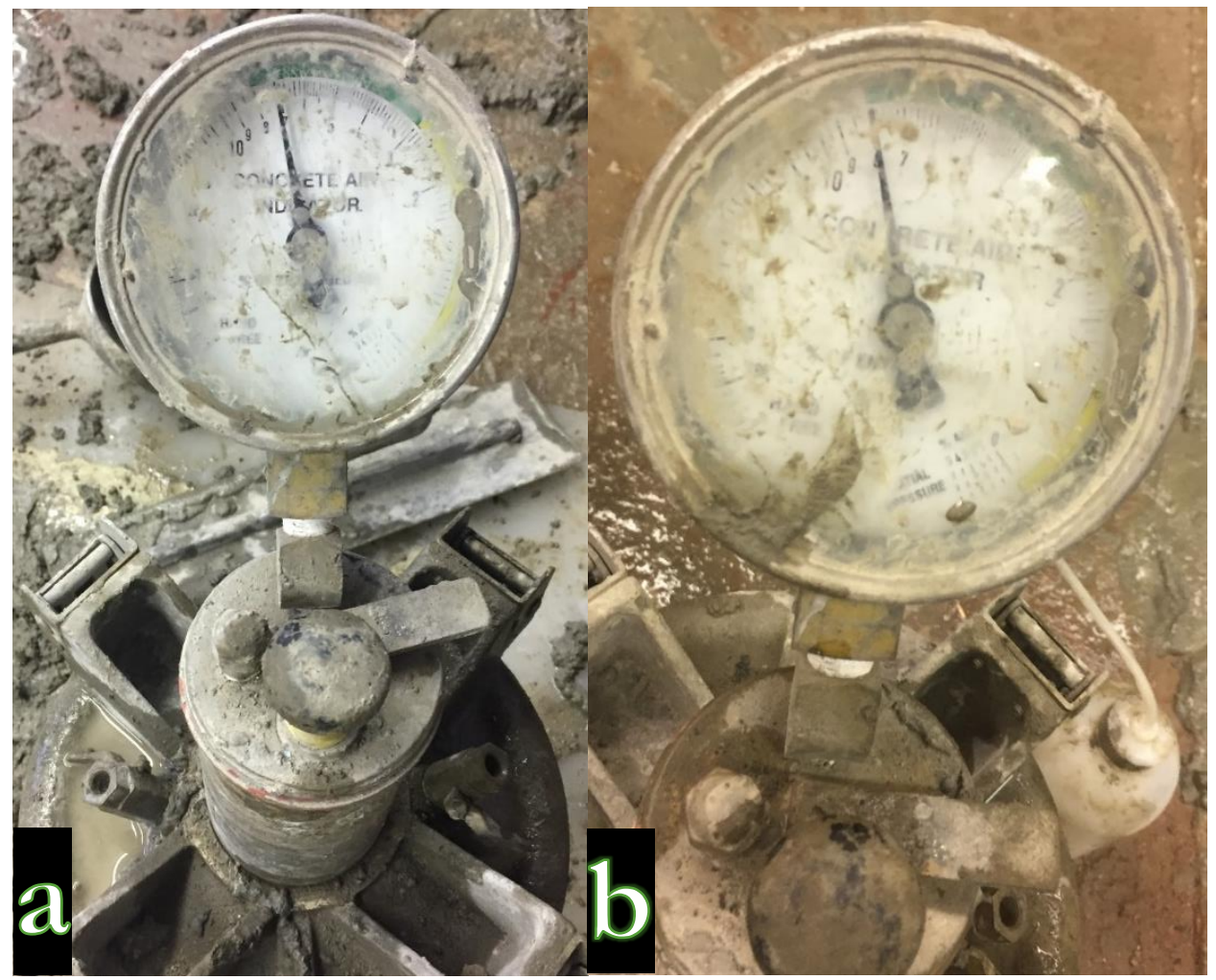

Figure 9(a): Air content for the OPC.

Figure9(b): Air content for the SCC castings.

\subsubsection{SLUMP}

Slump spread testing is done following ASTM C1611/C1611M-14 for self-consolidating concrete, and slump testing ASTM C143/C143M-15a for both slag and ordinary Portland cement concrete. To conduct slump on SCC a sample of freshly mixed concrete will be placed, as one lift, into an upside-down pre-wetted slump mold on top of a smooth pre-watered baseboard. After the mold is filled, use a strike-off bar to level the top of the concrete and be sure to remove any concrete around the base or on the baseboard. The mold will then be lifted, and the concrete will be allowed to spread until it stops on its own. The diameter of the spread should be measured twice at two positions perpendicular to each other. The average of these two values will give the slump 
spread of the SCC. For the test to be valid, the two diameters should not have a difference of more than $50 \mathrm{~mm}$, and the test should be completed within a $2 \frac{1}{2}$ min time frame.

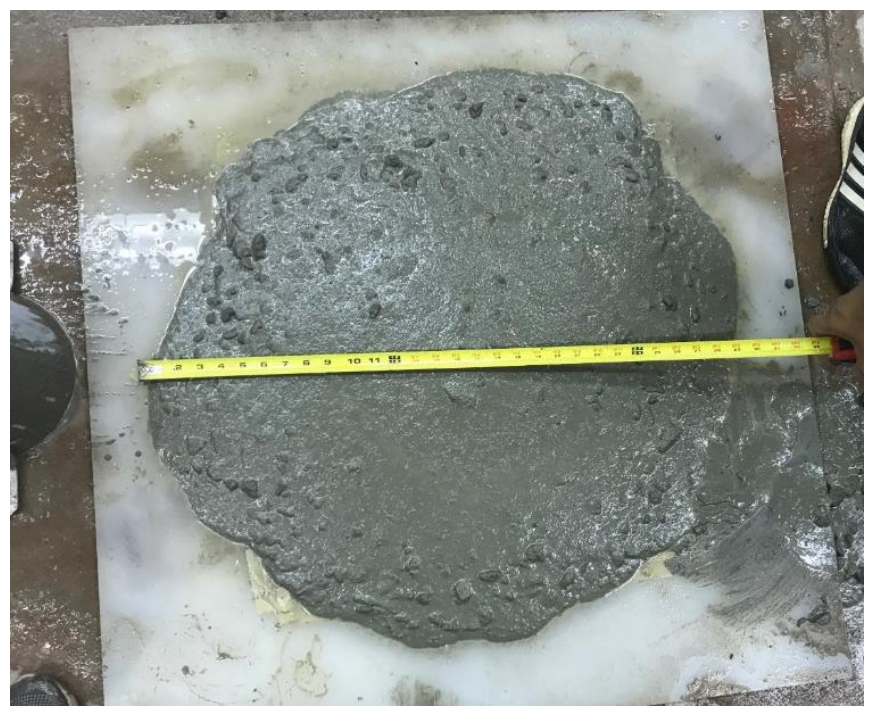

Figure 10: Slump Spread Test preformed on the SCC casting used in this research.

When conducting slump for OPC and Slag concrete, the fresh concrete is added to the dampened mold in three roughly even lifts. Between each lift, the concert should be rodded twentyfive times. The bottom layer should be rodded through its entire depth. For the second and third layers, the rodding should go through the layer as well as one inch into the layer beneath it. After rodding the last layer strike off the top surface. The mold should then be lifted over a five-second time frame. The mold should then be flipped upside-down and place next to the concrete pile. Take the rodding bar and lay it on top of the mold protruding out and over the concrete pile. With the use of a ruler or measuring tape, measure the height between the top of the concrete pile and the rodding bar. This value in inches is the slump.

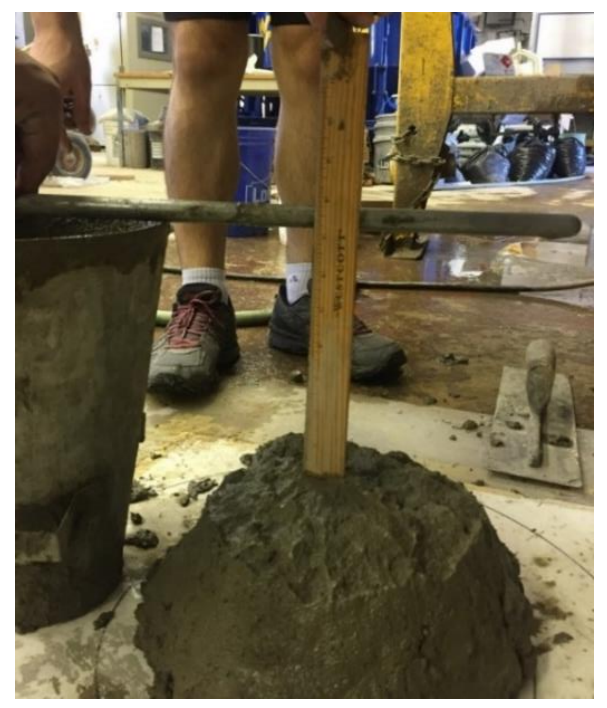

Figure 11: Slump Test results for OPC concrete casting. 


\subsection{TESTING}

\subsubsection{STRENGTH-COMPRESSION}

To test the compression strength of concrete, follow the ASTM C39/C39M. For this process, concrete 6inx12in cylinders are cast. The cylinder molds are removed at twenty-four hours and then placed in a water bath to cure. At intervals of 1day, 3days, 7days, 14days, and 28days, three specimens are removed from the water bath and tested for strength. This process involves taking a specimen and placing it between two pads and then using a hydraulic press, apply pressure to the sample. When the specimen fails, the hydraulic press shows the highest pressure the concrete could withstand before failure. This value can then be used with Equation 9 to calculate the compressive strength of the concrete at that time. ${ }^{17}$ The process is repeated with the second specimen. If the pressure between the first and second cylinder is different by $14 \%$, or more, of the average, then a third specimen needs to be tested. ${ }^{17}$

$$
\text { Equation 9: } f_{c m}=\frac{4 P_{\max }}{\pi D^{2}}
$$

where:

$f_{c m}=$ compressive strength, MPa [psi],

$P_{\max }=$ maximum load, $\mathrm{kN}[\mathrm{lbf}]$, and

$D^{\prime}=$ average measured diameter, $\mathrm{mm}$ [in.].

\subsubsection{STRENGTH-TENSILE}

To test the tensile strength, ASTM C496/C496M was followed. Per the standard, 6inx12in specimens are created for tensile strength testing. The specimens are unmolded at twenty-four hours and then placed in a water bath of room temperature or slightly warmer, the water temperature should be selected based on the curing desired, but should always be recorded and kept consistent. At different time intervals, specimens can be removed to be tested. For this experiment, the tensile strength was only used on the specimens that were used in the rapid chloride penetration testing. To test the specimens, they are laid on their sides, on a curved wooden plank to keep the specimens from rolling or shifting during the testing, and then placed in a hydraulic press. To create a tensile splitting strength testing a steel bar should be placed between the hydraulic press and the top of the concrete specimen to concentrate the load. The pressure will then gradually add pressure until the concrete fails, failure should produce a nearly straight line down the center of the concrete specimen, creating two halves. The failure pressure is then used with Equation 10 to calculate the tensile strength. ${ }^{18}$ Complete this process at least two times for each type of concrete, with the need for a third if the first two have pressures differing by more than $14 \%$ of the average. 


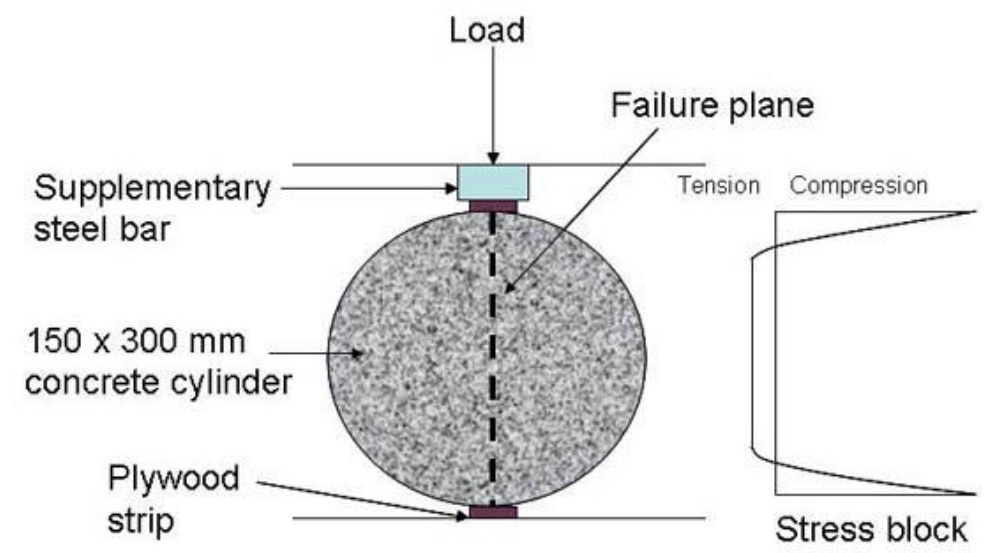

Figure 12: Set-up and predicted failure path of a specimen undergoing tensile-strength testing. ${ }^{36}$

$$
\begin{aligned}
& \text { Equation 10: } \mathrm{T}=\frac{2 P}{\pi l d} \\
& \text { Where: } \\
& \mathrm{T}=\text { splitting tensile strength, MPa [psi], } \\
& \mathrm{P}=\text { maximum applied load indicated by the testing machine, } \mathrm{N}[\mathrm{lbf}], \\
& \mathrm{l}=\text { length }=300 \mathrm{~mm}, \\
& \mathrm{~d}=\text { diameter }=150 \mathrm{~mm} .
\end{aligned}
$$

\subsection{PERMEABILITY AND DURABILITY}

\subsubsection{PONDING}

Two specimens for each concrete mix design were cast in 4 inx 8 in cylinders. The molds are removed after twenty-four hours, and then the specimens are placed in a water bath, at $72^{\circ} \mathrm{F}$, to cure for a minimum of 54 days. When the specimens are ready to be used, they are removed from the water bath and allowed to dry for twenty-four hours. After drying the outside of the specimens should be coated in a thick concrete epoxy, being careful to leave the top and bottom surfaces free from coating. Once the first coat is dry a second and third coat is applied to ensure a sealed outer surface. The specimens then have 4 in plastic cuffs added to the top of each cylinder. Before placing the cuff on to the cylinder, the inside of the cuff is painted with the same epoxy and then immediately slid on to the cylinder, to allow it to seal to the sample. Once the epoxy dries, each sample has hot glue added to the inside border and waterproof cocking added to the outside border. These measures were done to ensure minimal leaking. 


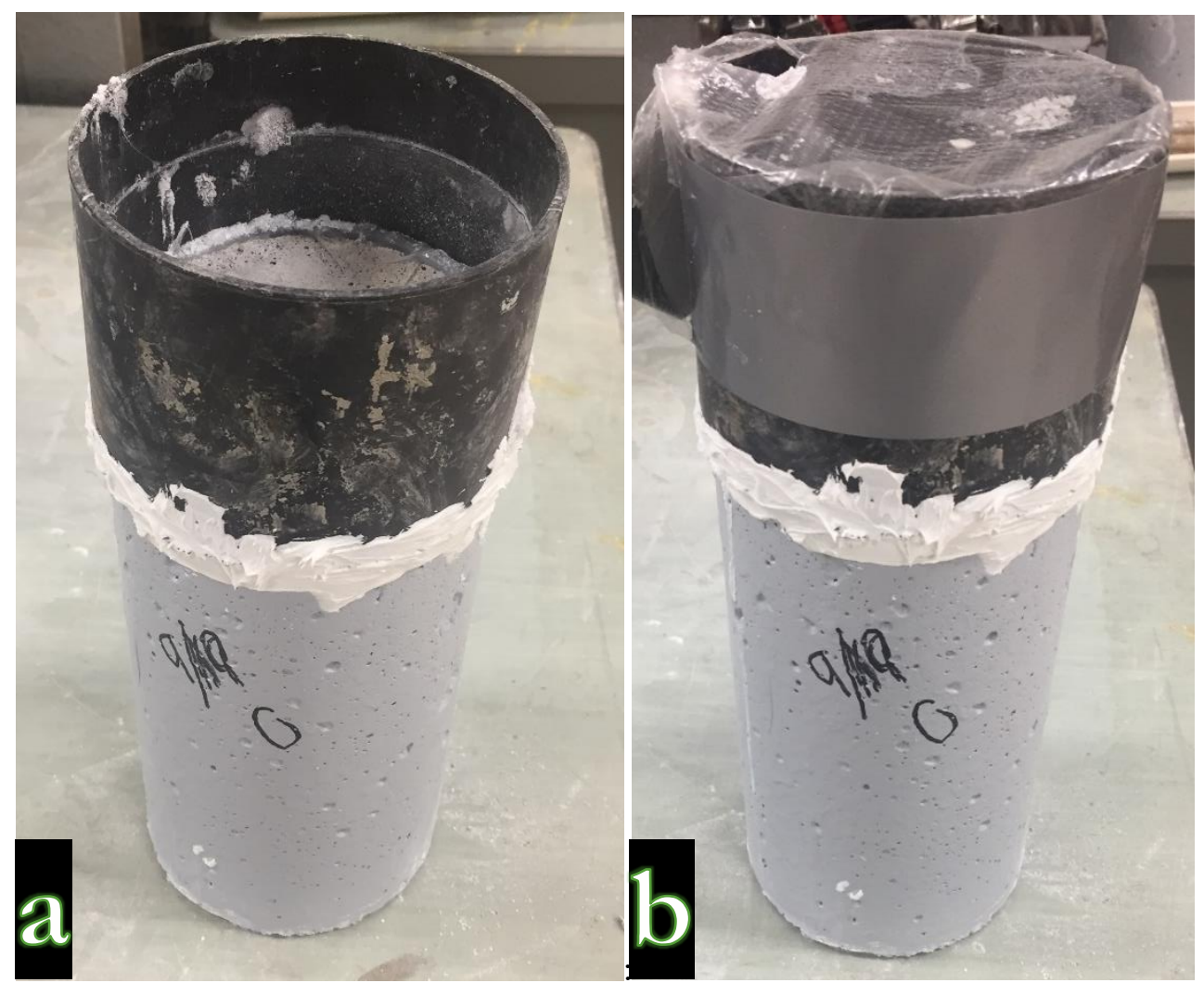

Figure 13(a): Ponding sample with dike, uncovered

Figure 13(b): Ponding sample with dike, covered.

As stated in ASTM C1543 - 10a, a water mixture of 3\% NaCl by mass is added to the cuff of each cylinder with a minimum depth of $15 \pm 5 \mathrm{~mm}$. Each cylinder is then covered with a clear plastic wrap and sealed with tape to keep water from evaporating. If the height of the solution in the cuff drops, add more mixture to each cylinder to keep a consistent depth. At sixty days, the cuffs are emptied and refilled with fresh mixture. This process continues for ninety days, after which the cuffs are emptied and removed. The cylinders are then left to dry for forty-eight hours.

When the samples are ready to be tested, a core is drilled through the center of each specimen, following the ASTM C42/C42M. At different intervals of 5mm, the core is tested for chloride concentration by being ground and then tested with a titration process. The chloride content will be determined by the core and the background content ASTM C1152/C1152M. The chloride content should be determined until a depth of $65 \mathrm{~mm}$ is reached or until there are two consecutive samples that show no difference in chloride content. This data can then be graphed to show the penetration of chloride into each cylinder. 


\subsubsection{CHLORIDE TESTING OF PONDING SAMPLES}

\subsection{ASTM}

Once samples have been collected from the ponding specimens, they must go through a process of testing to determine the total chloride concentration. The following procedure will be conducted for all the samples, except for the slag samples. Slag specimens will need to be pretreated with hydrogen peroxide, to neutralize the chloride found in the sulfur of the aggregate as well as the slag powder. To start, a sample will need to be sieved through a No. $20(850-\mu)$ and then blended by conning the sample from one piece of glazed or waxed paper to the next and back ten times, following the ASTM C702/C702M. Weigh out 10.00 grams of the sample and place into a beaker with $75 \mathrm{~mL}$ of reagent grade water. Once the mixture is stirred, slowly add $25 \mathrm{~mL}$ of diluted nitric acid. This mixture should be thoroughly mixed to ensure no lumps, and then add three drops of methyl orange indicator. The beaker should then be covered with a water glass and then be left to sit for 1-2 minutes. If the mixture is not a pink color, then add more nitric acid, drop by drop, until the mixture is a pink or reddish color, and then add ten additional drops.

Once the base mixture is completed, the beaker should be heated to a rapped boil, and then immediately removed from the heat. The sample will then be filtered through a 9-cm coarsetextured filter paper into a Buchner funnel and filtration flask using suction, and then allow the sample to cool. Be sure that the sample has a total volume under $175 \mathrm{~mL}$. Two mL of $0.05 \mathrm{~N} \mathrm{NaCl}$ solution should then be piped into the sample beaker and then add a TFE-fluorocarbon coated stir bar, to be used with a magnetic stirring plate. Electrodes should be submerged into the beaker, and begin titrating the specimen. Record the amount of $0.05 \mathrm{~N}$ silver nitrate solution that is used to give a readout of $-60.0 \mathrm{mV}$ of the equivalence point of the background water. Continue to titrate at $0.20 \mathrm{~mL}$ increments until the equivalence point is reached, and then three more readings after that.

After the final readings are recorded the chloride percent by mass of concrete can be calculated. Start by subtracting the equivalence point of the background water, from that of the total solution. Equation 11 shows the calculation presented in ASTM C1152/C1152M, for obtaining the chloride concentration. This result can then be used with the results from each sample to find the distribution of chloride through each specimen.

$$
\begin{gathered}
\text { Equation 11: } \mathrm{C} 1 \%=3.545[(\mathrm{~V} 1-\mathrm{V} 2) \mathrm{N}] / \mathrm{W} \\
\text { Where: } \\
V_{1}=\text { milliliters of } 0.05 \mathrm{~N} \mathrm{AgNO} 3 \text { solution used for sample } \\
\text { titration (equivalence point), } \\
V_{2}=\text { milliliters of } 0.05 \mathrm{~N} \mathrm{AgNO} 3 \text { solution used for blank } \\
\text { titration (equivalence point), } \\
N=\text { exact normality of } 0.05 \mathrm{~N} \mathrm{AgNO} 3 \text { solution, } \\
W=\text { mass of sample, } \mathrm{g} .
\end{gathered}
$$


Ion selective electrode probes are based on an ion selective electrode theory which converts a specific ion found in a solution into a voltage. This voltage can then indicate a logarithmic amount of the chloride concentration. Before the test can start, a reference curve needs to be produced, and each reference curve is only valid for the day the testing is being done. Run the chloride testing using the ion selective electrode probe on different solutions with known concentrations. For the samples used to reference the chloride ponding samples, chloride solutions of $0 \%, 5 \%, 10 \%, 20 \%, 35 \%$, and $50 \% \mathrm{mg}$ of CL/L should be conducted. The log10 of these concentrations should then be graphed versus the $\mathrm{mV}$ reading. The graph should have the best fit line calculated and produced.

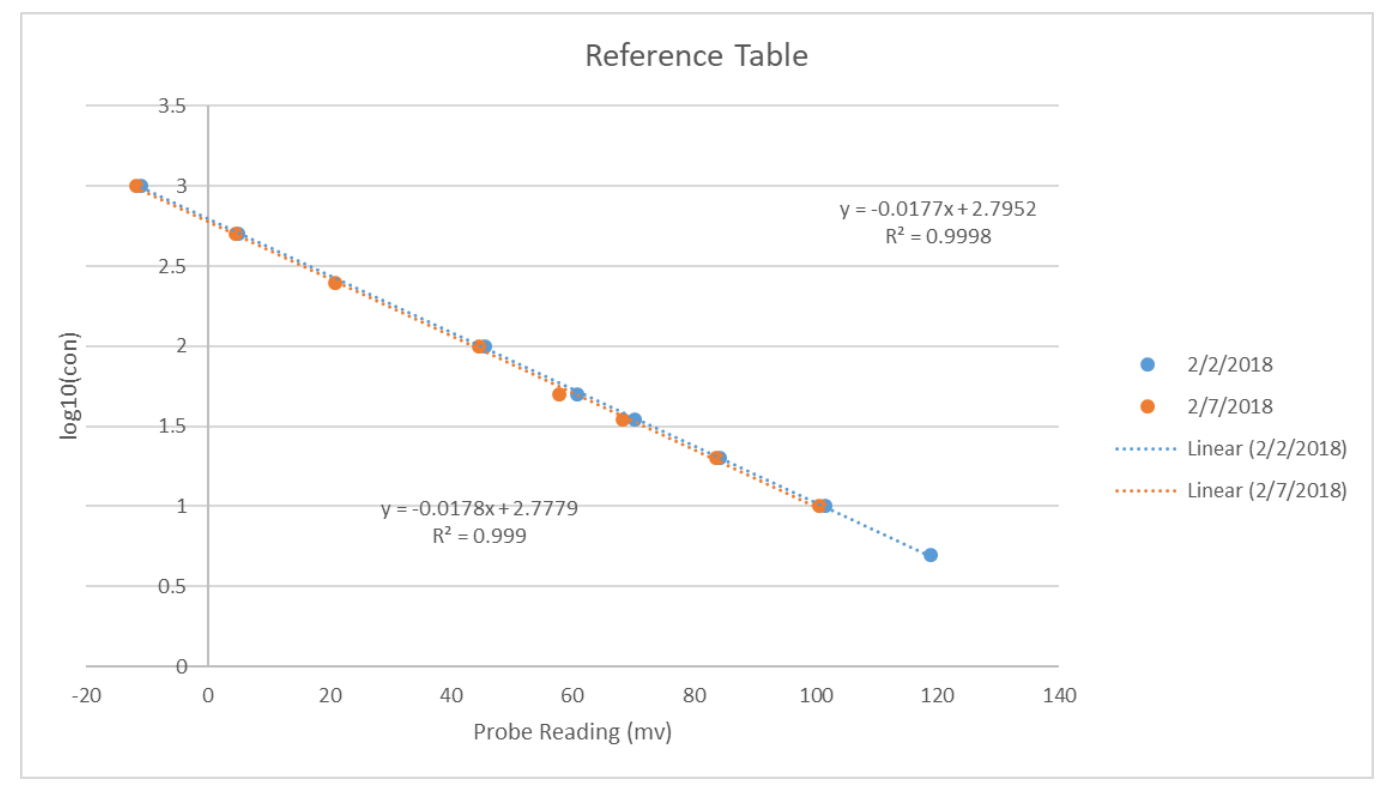

Figure 14: Reference table used to obtain the formula for calculating the concentration of chloride in concrete samples.

To start the chloride testing process using the electrode probe concrete samples should be ground the same as in the ASTM methods. Once the powder is prepared and funneled, $10 \pm 0.001$ grams should be weighed out. The sample should be added to $100 \mathrm{~mL}$ of deionized water and then stirred on a magnetic stirring plate for five minutes. The sample would then be left to leach for five minutes, Figure 15, or until enough particles have settled so a $50 \mathrm{~mL}$ sample can be taken. The newly leached sample can then be used with the ion selective electrode probe, Figure 16. Place the magnetic bar in the sample and place it on the magnetic stirrer plate, set the stirrer to one and let the probe run until it states ready on the screen. Be sure that the electrode probe does not touch the side or bottom of the glass jars or the magnetic stirring bar. Record the reading in milli-volts and continue to the next sample. 


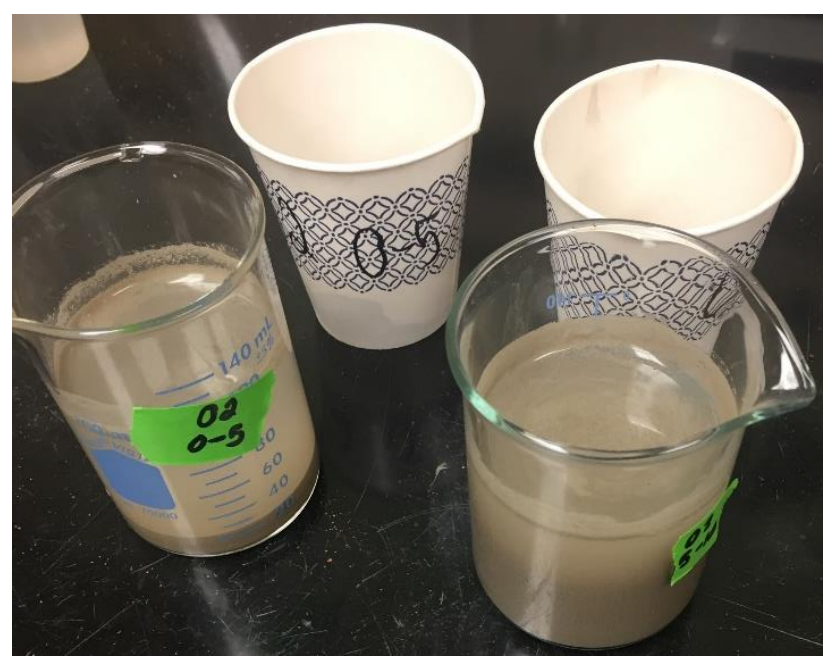

Figure 15: Sample on the right has just been stirred for the required five minutes and the sample on the left has been left to leach for five minutes.

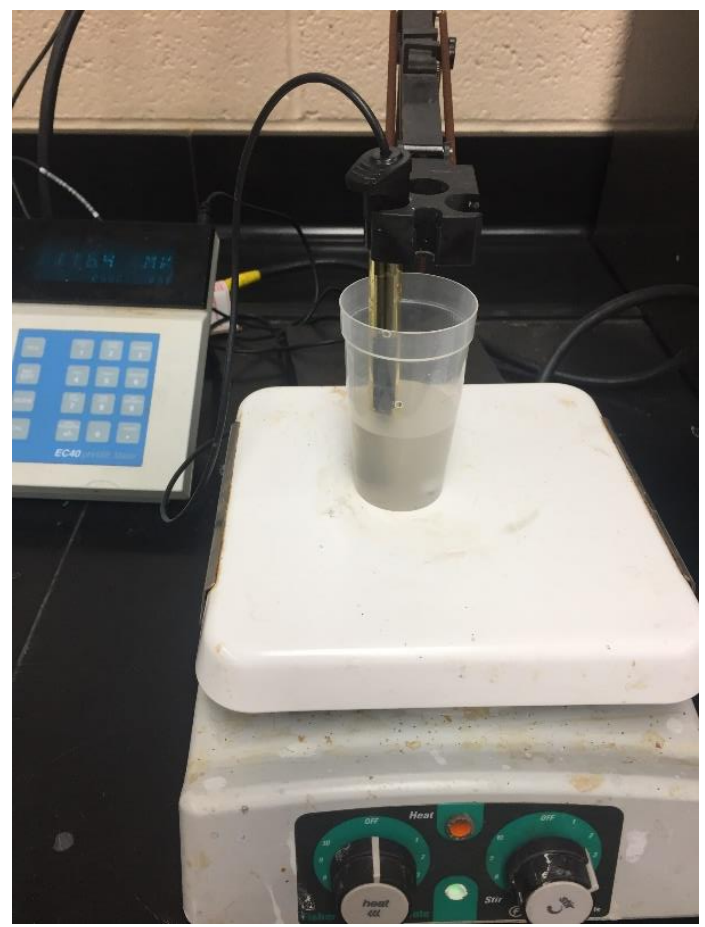

Figure 16: The process of determining the chloride level, by using the electro-probe to determine the $\mathrm{mV}$ reading of a sample.

Once the data is collected, use the $\mathrm{mV}$ reading in the equation produced in the reference best-fit line to calculate the $\log 10$ of the concentration, Equation 12. The concentration can then be back-tracked using the inverse $\log 10$. The concentration can be graphed against the depth of the sample to produce a curve showing the distribution of chloride through each sample. If the amount of concrete sample used varies, this would need to be accounted for in the calculation of the concentration. 


$$
\begin{aligned}
& \text { Equation 12: } C=\frac{10^{f_{B F E}(V)}}{m} \\
& \mathrm{~V}=\text { Reading from the electron probe }(\mathrm{mV}) . \\
& \mathrm{f}_{\mathrm{BFE}}=\text { Function created from the best fit line } \\
& \mathrm{m}=\text { Original mass of powder used in the testing. } \\
& \mathrm{C}=\text { The chloride concentration of the sample, per gram of powder. }
\end{aligned}
$$

\subsubsection{RCPT}

Rapid chloride penetration testing (RCPT) starts by preparing a specimen with a thickness of $50 \mathrm{~mm} \pm 3 \mathrm{~mm}$. Starting with a $4 \times 8$ in cylinder of concrete cut off a two-inch sample from one end of the cylinder using a wet diamond saw. Then use a polisher to remove any burs or indentations at the end of the concrete. Use the concrete sealer to paint the sides of the sample, being careful not to paint on the ends of the sample. Allow for proper curing of the sealer, then apply a second coat of sealer to ensure all pores and indentations are filled. Once the sealer has dried and is no longer sticky to the touch, the sample can be placed inside the vacuum chamber.

Once inside of the vacuum chamber, the top and bottom pieces of the bell-chamber are sealed with the use of Vaseline. Once sealed, ensure that the stock-clock to the water valve is closed and that the vacuum stopcock is open to the bell. Run the pump until the pressure inside of the bell reaches a minimum of $50 \mathrm{~mm} \mathrm{Hg}(6650 \mathrm{~Pa})$. Check to make sure that the air stopcock is closed and then close off the vacuum stopcock to maintain the pressure inside of the bell. Maintain the $50 \mathrm{~mm}$ Hg pressure for three hours.

While the cylinder is under vacuum de-aerated water can be prepared. Fill a pot with demineralized water and bring it to a boil. Allow the water to be boiled for a short time and then place a lid on the pot while removing the pot from the heat. Once the water is cooled, it is ready for use in the experiment.

After the three hours of pressure, place the de-aerated water in the water tank of the bell chamber set-up. Be sure to check that the water stopcock is closed before adding the water. Once filled, place the cap back on top of the water tank and open the stopcock, allowing the water to fill the vacuumed bell. If more water is needed, close the water stopcock and fill the water tank again. Then close the cap while opening the water stopcock. Repeat this until all samples inside of the bell are entirely covered by the water. Check to make sure the vacuum is still below $50 \mathrm{~mm} \mathrm{Hg}$ and maintain this pressure for one hour, by running the pump for the entire hour. After the hour is up, turn off the pump and open the air stopcock to allow air to re-enter the bell. Leave the samples in the water for $18 \pm 2$ hours. After the allotted time remove the sample and blot it dry, then place it in an airtight container to maintain the moisture level at 95\% or higher. 
Take the previously prepared sample and mount it to the voltage cells. Start by applying two layers of adhesive electric tape to the edge of both sides of the sample. Then apply six to seven layers of fitting tape, use the best judgment on how much room is between the cylinder and the voltage cell walls. Take a thin layer of conductive metal, cut to the shape of the interior of the voltage cell with an extra extended piece bent into a cylinder, to be used with the alligator clamp of the power supply. This piece of metal should be placed into the cell and then apply a small layer of adhesive silicon around the edge of the voltage cell. Snuggly fit the sample into one voltage cell and then apply a construction adhesive silicon to the edge of the sample and the cell. Then apply another small layer of adhesive into the other cell and place the concrete cylinder into the other cell, being sure not to lose the seal previously made between the cylinder and the other cell. Finish by applying a layer of silicon to the edges of the second cell and the cylinder. Once the two sides of the cell are applied, add either C-clamps to the sides of the cell to ensure a tight seal, or apply screws through the two cells and tighten firmly using a wrench. Both methods of tightening the cells are pictured below. Be sure to allow this sealer to dry before starting any tests.

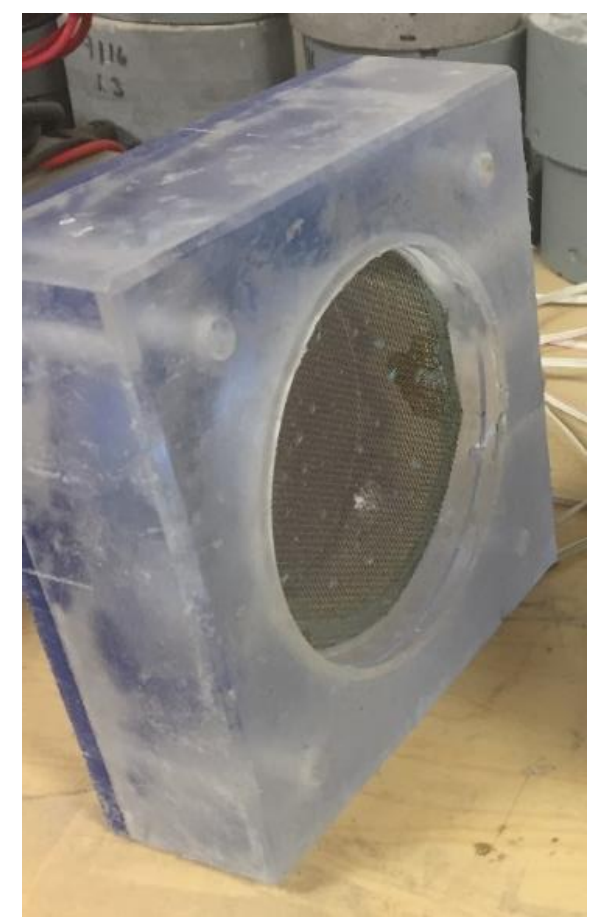

Figure 17: Inside of voltage cell, with conductive mesh in place. 


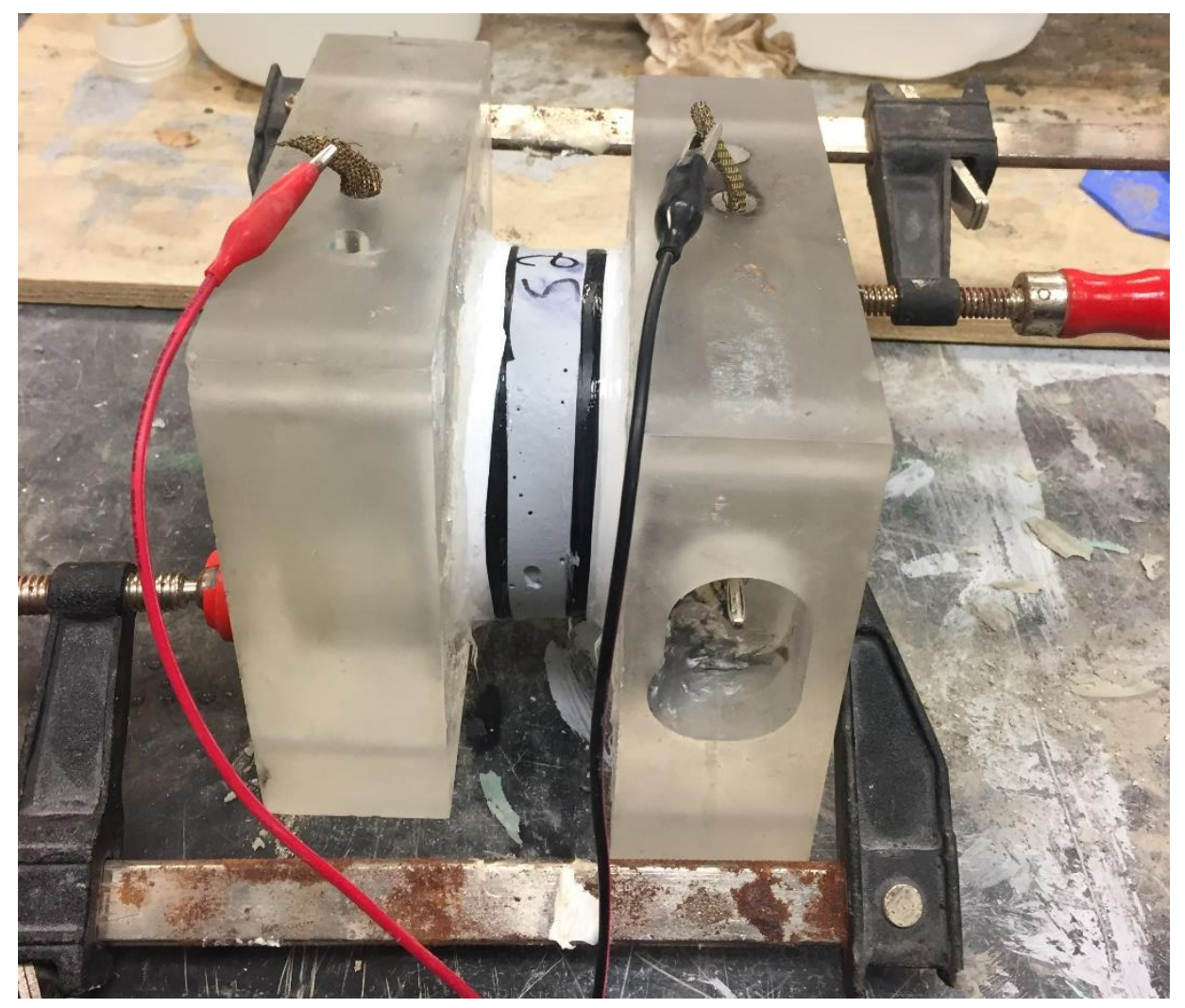

Figure 18: Voltage Cell fastened with C-clamps.

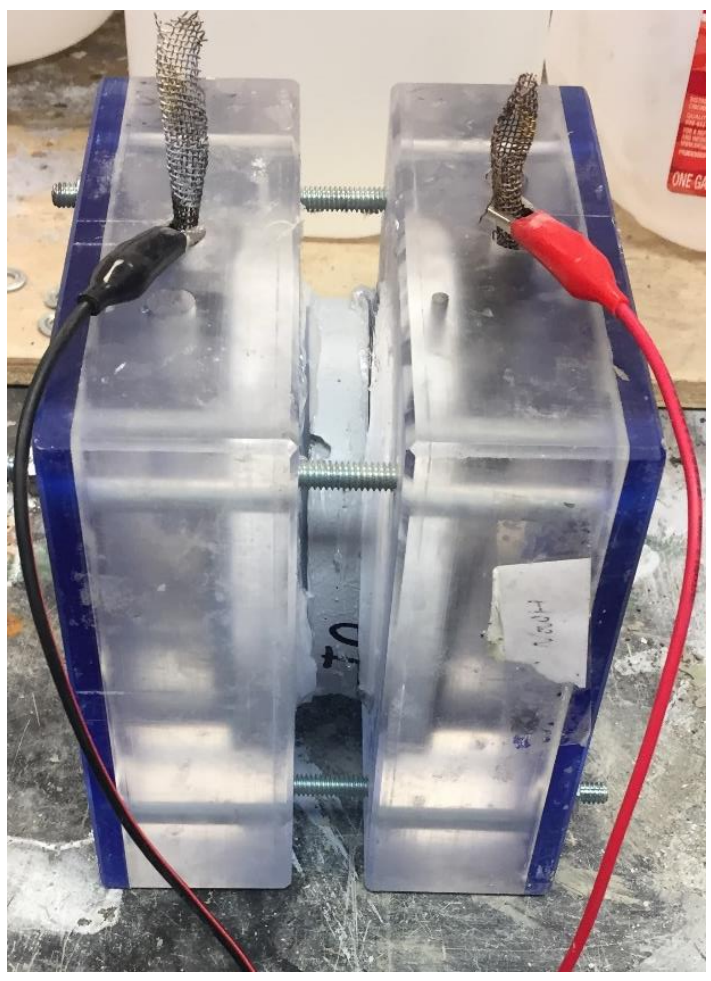

Figure 19: Voltage Cells attached with bolts. 
To run the test, fill one voltage cell, the one connected to the negative terminal of the power supply, with $3 \% \mathrm{NaCl}$ solution and the other side, connected to the positive terminal, with a $0.3 \mathrm{~N}$ $\mathrm{NaOH}$ solution. Connect the two ends to the lead wires using the protruding conductive mesh. Then connect the lead wires to voltage application and the data readout apparatus. Turn on the power supply to $60 \pm 0.1 \mathrm{~V}$ and allow the machines to warm up for at least fifteen minutes. When the device is ready, turn on the test power and then start the test. Record the initial current, charge, the temperatures of the voltage cell and the temperature of the solution. The temperature of all components must be in the range of $20-25^{\circ} \mathrm{C}$, repeat the measurements every 30 minutes for six hours. If the temperature of the solutions exceeds $90^{\circ} \mathrm{C}$, the test must be terminated to keep the solution from boiling. Once the test has been completed, remove the specimen, rinse the cell with water and then strip out and discard the outside sealer.

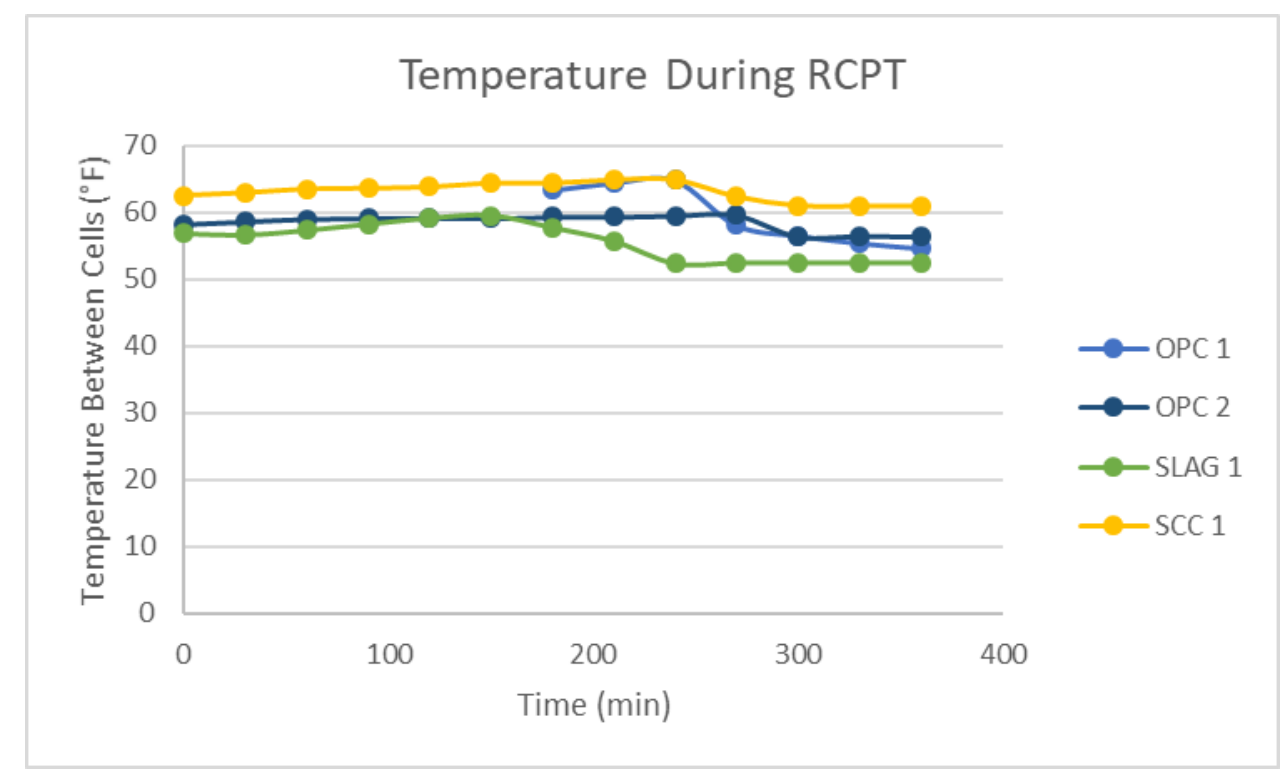

Figure 20: Temperature Change during RCPT. 


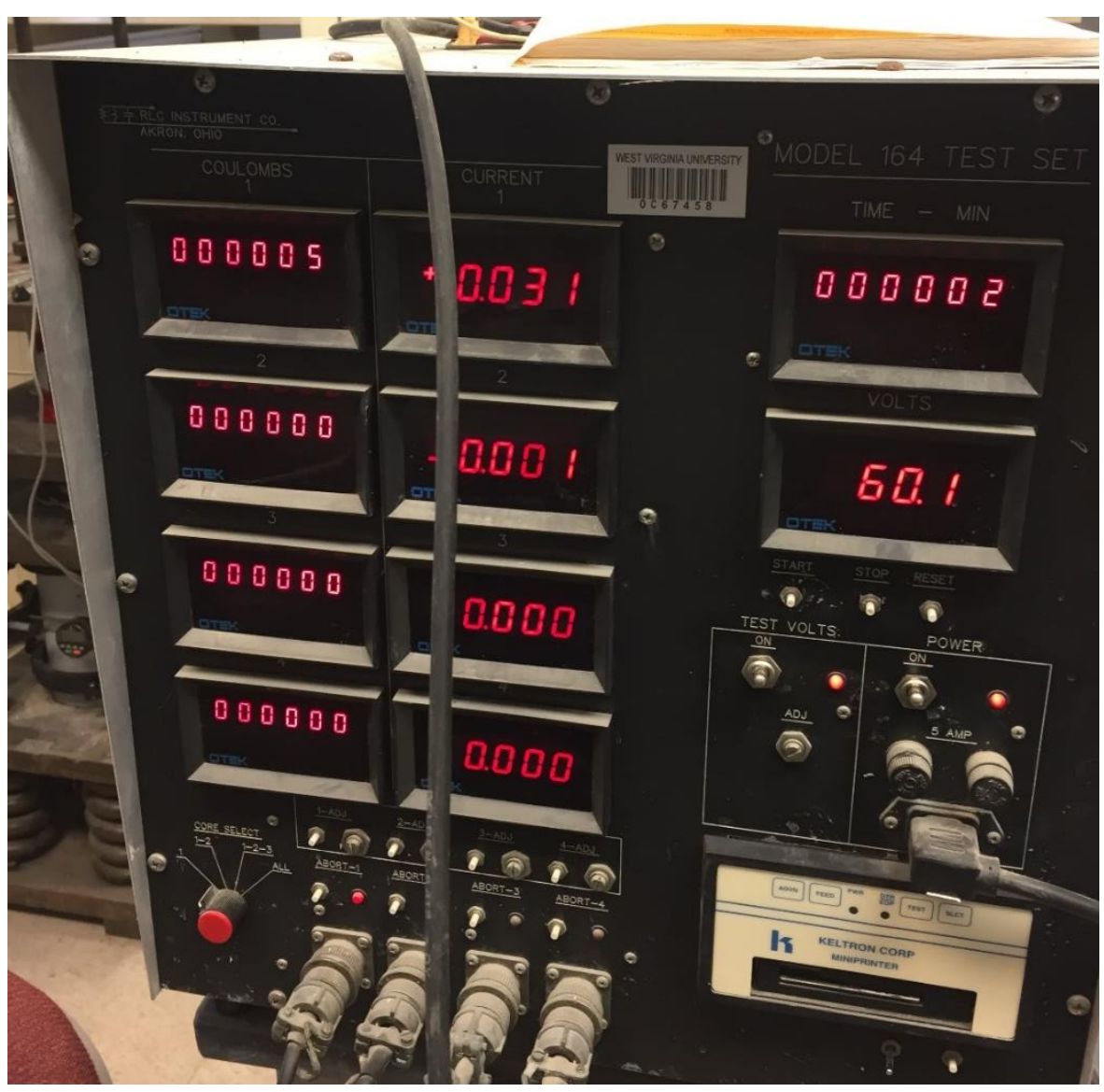

Figure 21: Output data from RCPT, machine gives the time the test has been running, current, voltage, and total charge passed.

The current in amperes should be plotted against the time in seconds. Draw the best fit curve to the data and use the area under the curve to obtain the charge passed during the test, in ampere-second. This value is then related to the conductivity of the concrete.

$$
\begin{aligned}
& \text { Equation 13: } Q=900\left(I_{0}+2 I_{30}+2 I_{60}+. .+2 I_{300}+2 I_{330}+I_{360}\right) \\
& \text { Where: } \\
& Q=\text { charge passed (coulombs), } \\
& I_{o}=\text { current (amperes) immediately after voltage is applied, and } \\
& I_{\mathrm{t}}=\text { current (amperes) at } \mathrm{t} \text { min after voltage is applied. }
\end{aligned}
$$

Conductivity correlates with chloride permeability. Samples who have a total charge passed as less than $<2,000$ coulombs are considered to have low chloride penetrability or less. This system shows a correlation of the permeability between different mix designs. 


\subsubsection{SILVER NITRATE}

To conduct Silver Nitrate testing the samples used in RCPT will have to be split using a tensile strength testing method. Once the samples are split silver nitrate can be applied to the inside of the concrete sample. Be careful to make sure that the silver nitrate does not come in contact with skin, by wearing protective clothing and gloves. The samples can then be observed to see the distribution of the chloride through the concrete. Measure the depth of the chloride at different locations across the diameter of the sample. These depths can then be averaged to show which samples had the most penetration.

\subsubsection{BENTZ - MULTI-SCALE MODELING}

To conduct permeability testing using Bentz's (2007) virtual model each mix design can be imported into a table, and the program will produce a result of the permeability of the mix design. The program requires the amount of water, cement, cementitious admixtures and air content. Based on the density, air and water-cement ratio of the mix design and an algorithm the total chloride output can be calculated. These results can be compared to the RCPT testing discussed earlier. 


\section{CHAPTER 5: RESULTS AND DISCUSSION}

\subsection{PONDING}

The ponding was done with a table ionized salt instead of lab grade $\mathrm{NaCl}$. This was done in error, so all results found should be recreated using the suitable high-grade $\mathrm{NaCl}$ required in the code. Although ionized table salt will produce a higher chloride reading than would be seen with lab grade NACI, it still should be a uniform increase in all samples. This increase should have little to no effect on the comparison between different types of concrete mixes, but it should be considered when compared to results found in other experiments.

Initially, after each ground concrete sample was collected, the entire sample was tested to find the chloride concentration of the sample. This process produced two main issues, the first being that the test results could not be reproduced for a sample after the initial test. This was a problem later when the results should have been replicated, so the process was adjusted. The second problem was that the samples containing over 20 grams of powder could not settle enough to produce $50 \mathrm{~mL}$ of clear sample to test. This provided data with massive drops and jumps that do not follow a consistent trend. This is most obvious in the testing done for the first SCC sample (SCC 1). The results produced for depths $5-25 \mathrm{~mm}$ do not follow the trend of the expected exponential curve.

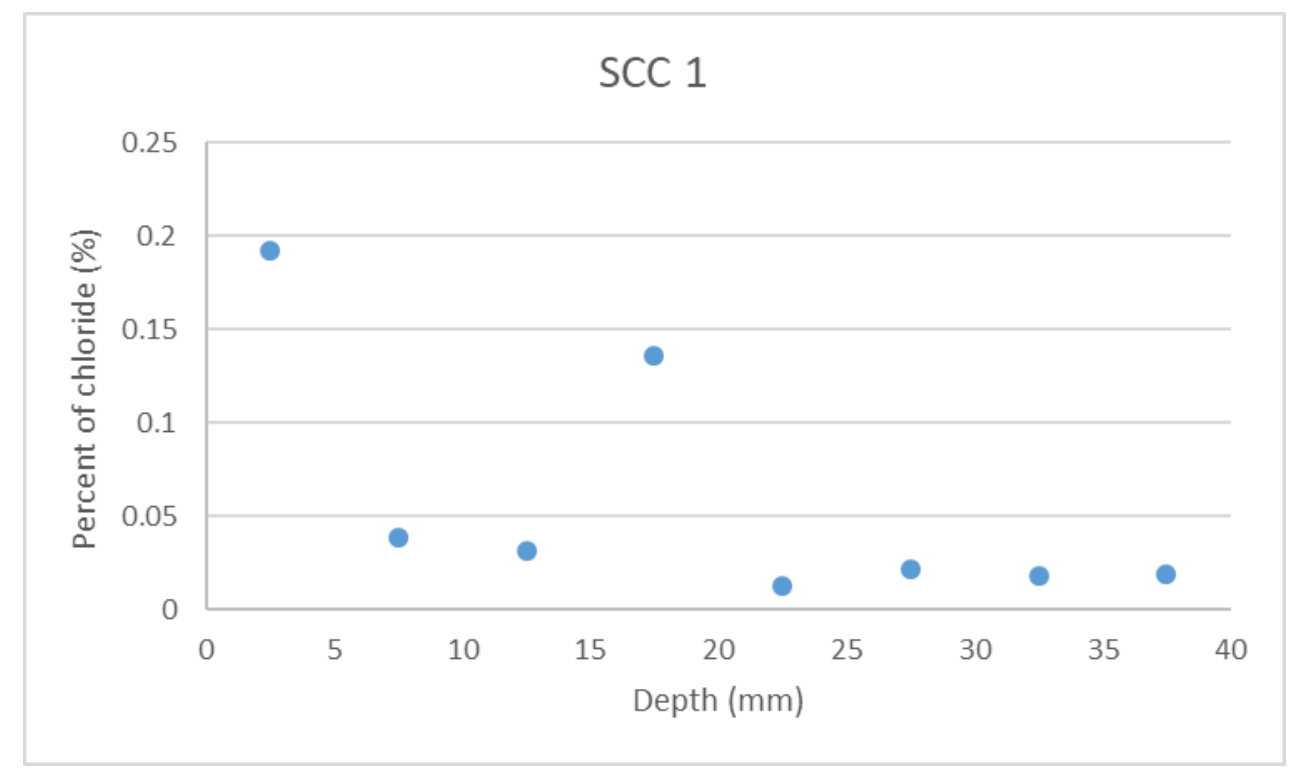

Figure 22: Graph of the chloride concentration of SCC1, vs. the depth of the sample (mm).

These problems were solved by extracting only ten grams of each sample for future tests. As shown in Figure 23, the samples for the second OPC sample (OPC 2) were tested using a uniform sample size. The graph created a clear and reasonable distribution of the concentration of chloride throughout the sample. 


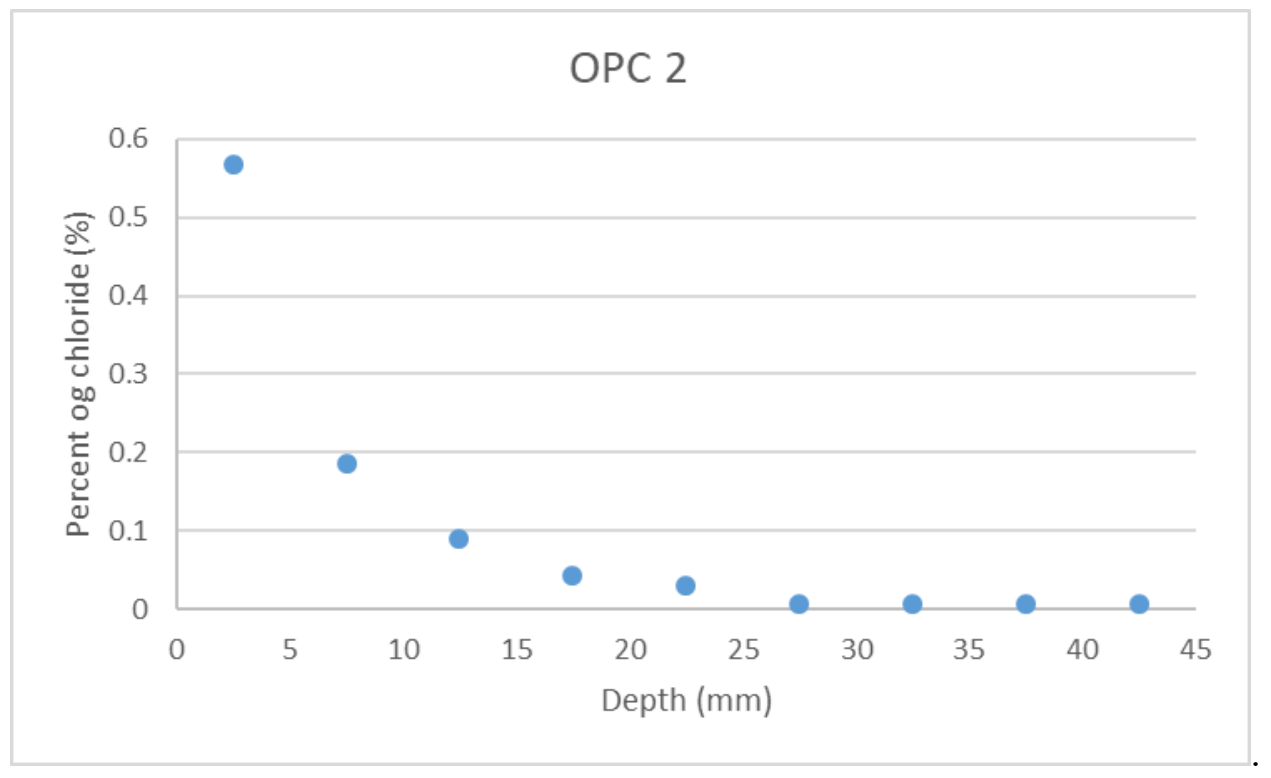

Figure 23: Graph of the Chloride concentration per gram of OPC 2 versus depth (mm).

Another issue discovered early on was the large depth size of each sample indicated in the ASTM C1543 - 10a code. The problem with using such considerable sample depths is that very few data points are created, because of this an exponential curve is not explicitly or accurately shown. This is a common concern with the ASTM code and was also shown in the results of Slag sample one (SLAG 1) when compared to that of the results for Slag sample two (SLAG 2). SlAG2 was tested at increments of $5 \mathrm{~mm}$ instead of $10 \mathrm{~mm}$ collected samples and $5 \mathrm{~mm}$ of discarded specimens, which was used in SLAG1, as was suggested in the codes.

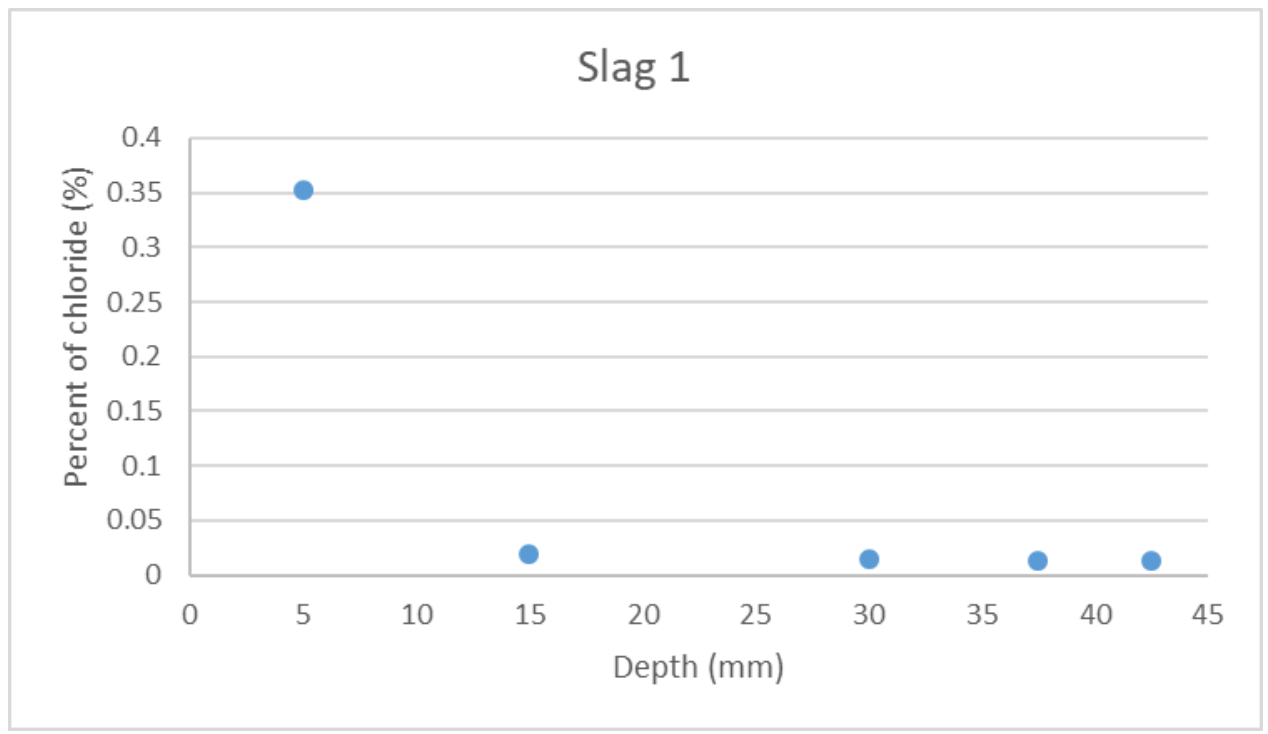

Figure 24: Graph of the chloride concentration per gram vs. depth (mm) for sample Slag 1. 


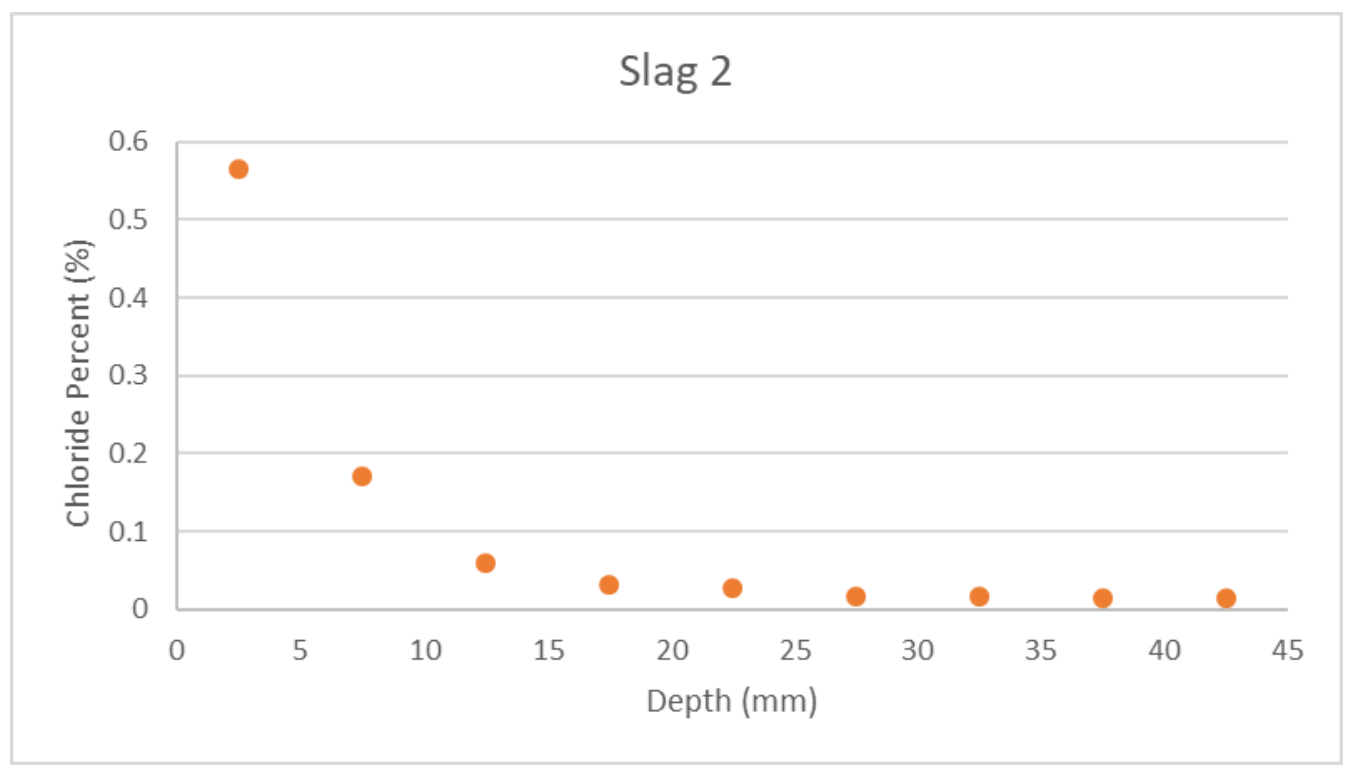

Figure 25: Graph of the concentration of chloride per gram of sample vs. depth of sample (mm).

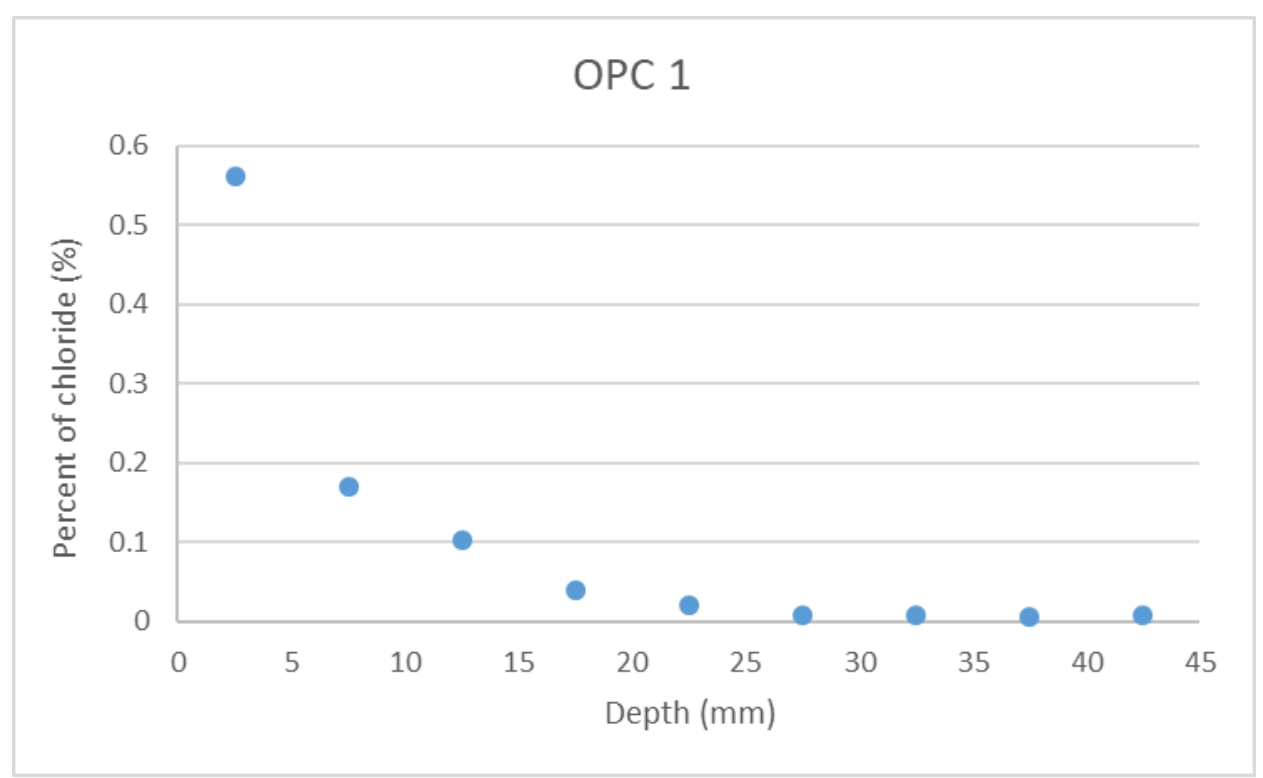

Figure 26: Test results from the chloride concentrating testing. 


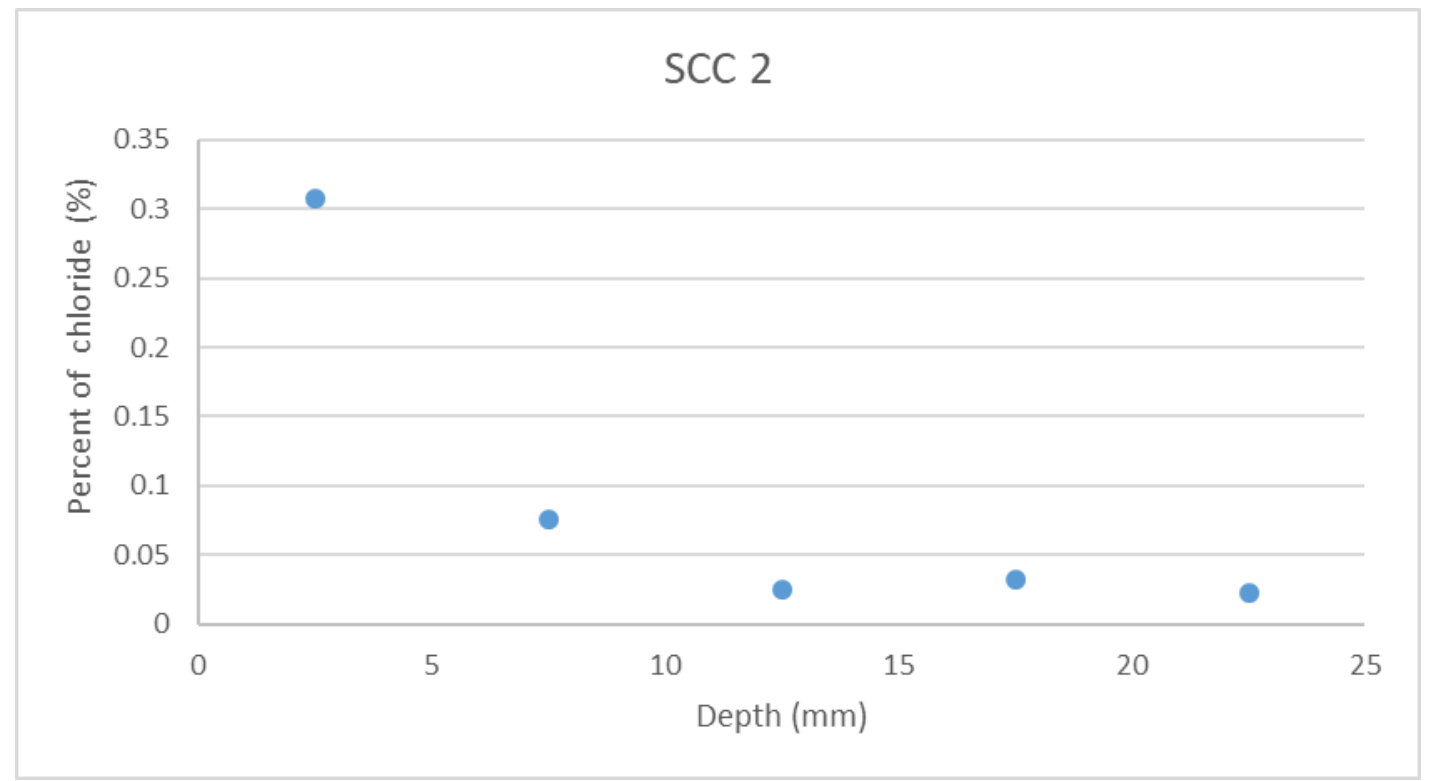

Figure 27: Test Results from the chloride concentration testing.

The results were combined to show a correlation between chloride permeability and type of concrete. The first graph in Figure 28, shows the raw data collected from the ponding samples. The data shows no clear indication of a trend due to the outliners discussed earlier. When the best fit line from each set of data is used for the comparison a more consistent trend starts to form in the data. However, SCC 1 and SCC 2 tend to show a significant difference in chloride permeability. SCC 1 was removed from the results to remove the jumps and drops, caused by the large sample size. A trend shows that both Slag and SCC concrete mixtures have lower chloride concentration than OPC for the entire sample depth, with SCC having the lowest chloride concentration.

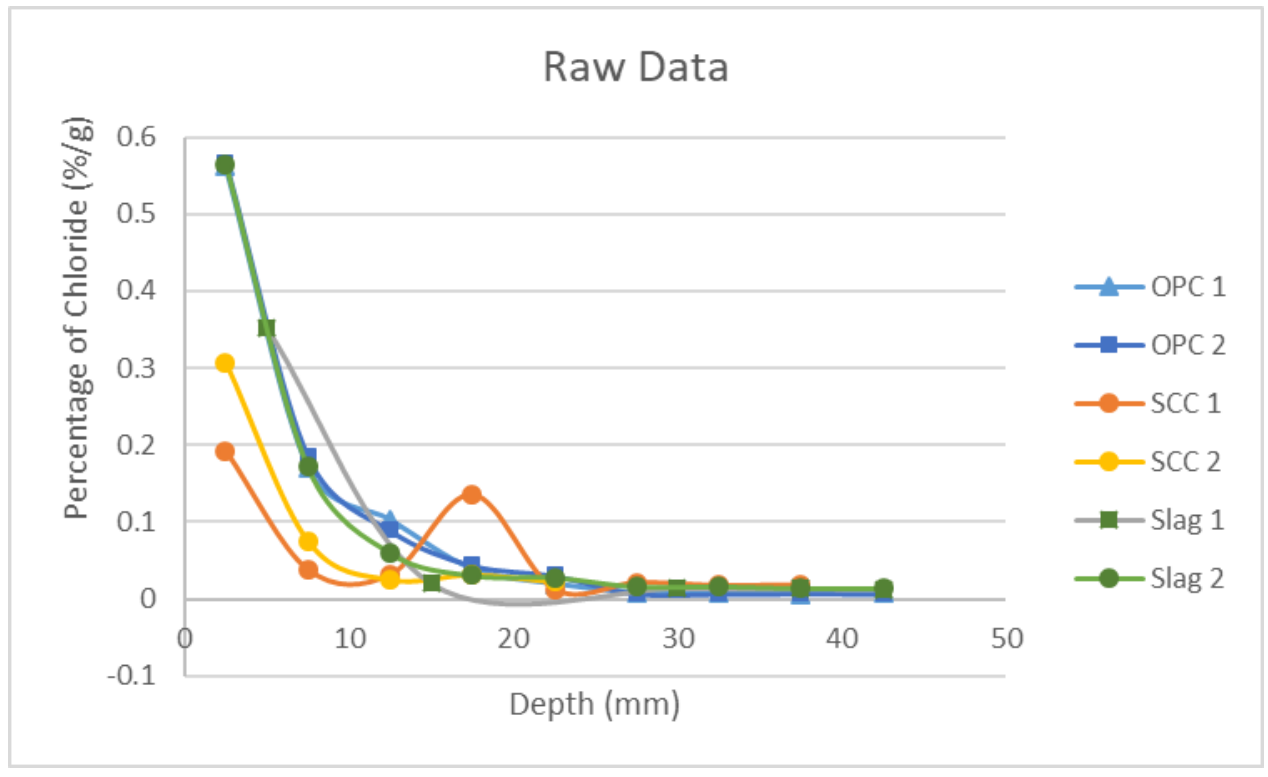

Figure 28: Chloride concentration per gram of sample vs. depth(mm) for the raw data. 


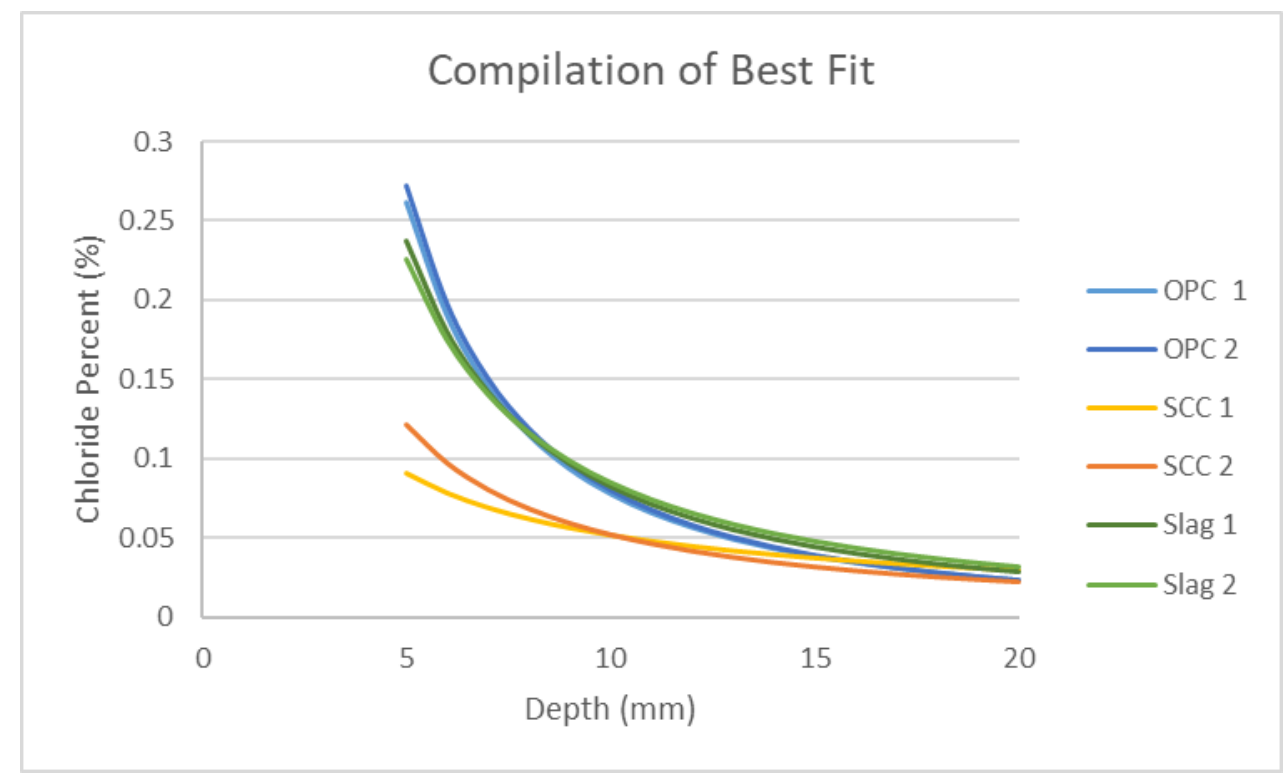

Figure 29: Concentration of chloride vs. depth $(\mathrm{mm})$ produced with the best fit line from each previous graph.

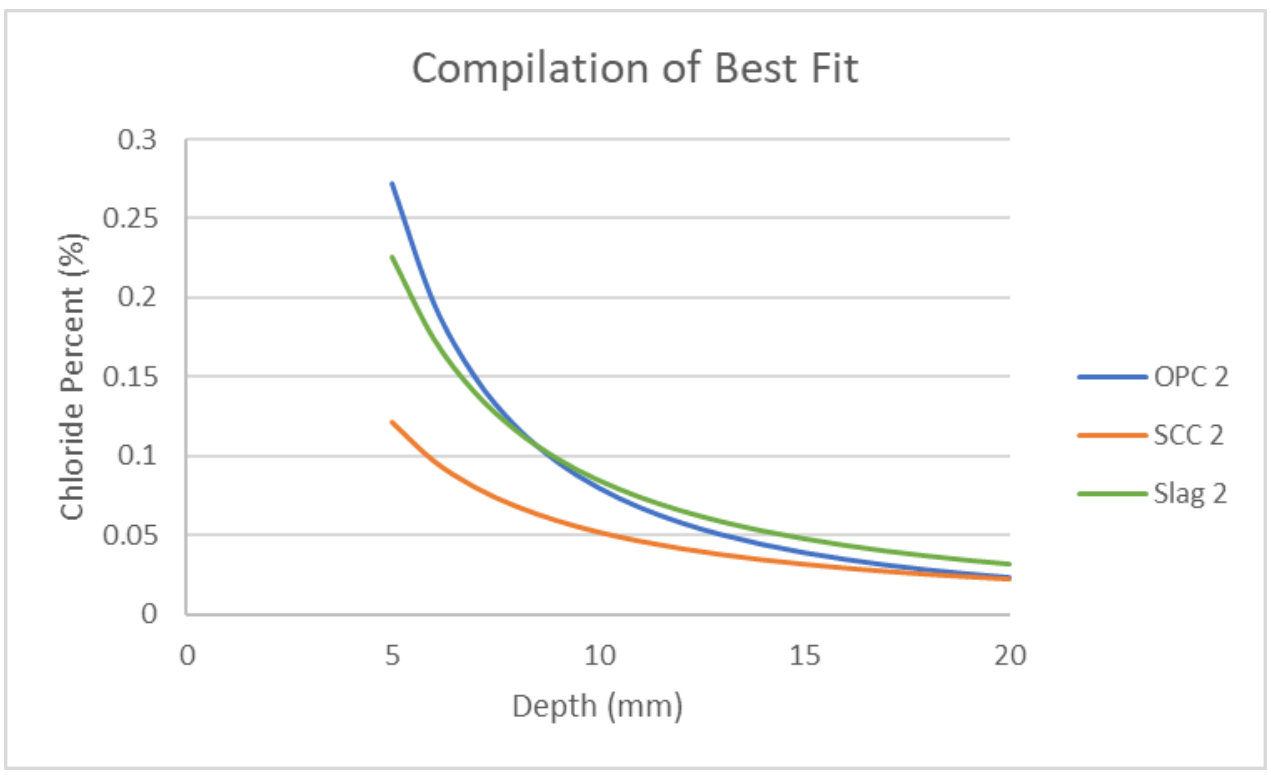

Figure 30: The chloride concentration per gram of sample vs. depth ( $\mathrm{mm})$, produced from the best fit line of each sample, with the outliner data removed and the average taken of the remaining samples for each mixture type.

Slag is composed of sulfur which creates a base chloride in the concrete samples. This systematic error can create an allusion that it has a higher concentration of chloride in it then what is caused by ponding. The error can be eliminated by subtracting the base concentration found when two consecutive samples have the same $\mathrm{mV}$ reading. This process was done for all samples so that the chloride level found in the original concrete is removed from the data. This produces a graph with a very similar slag and OPC results. 


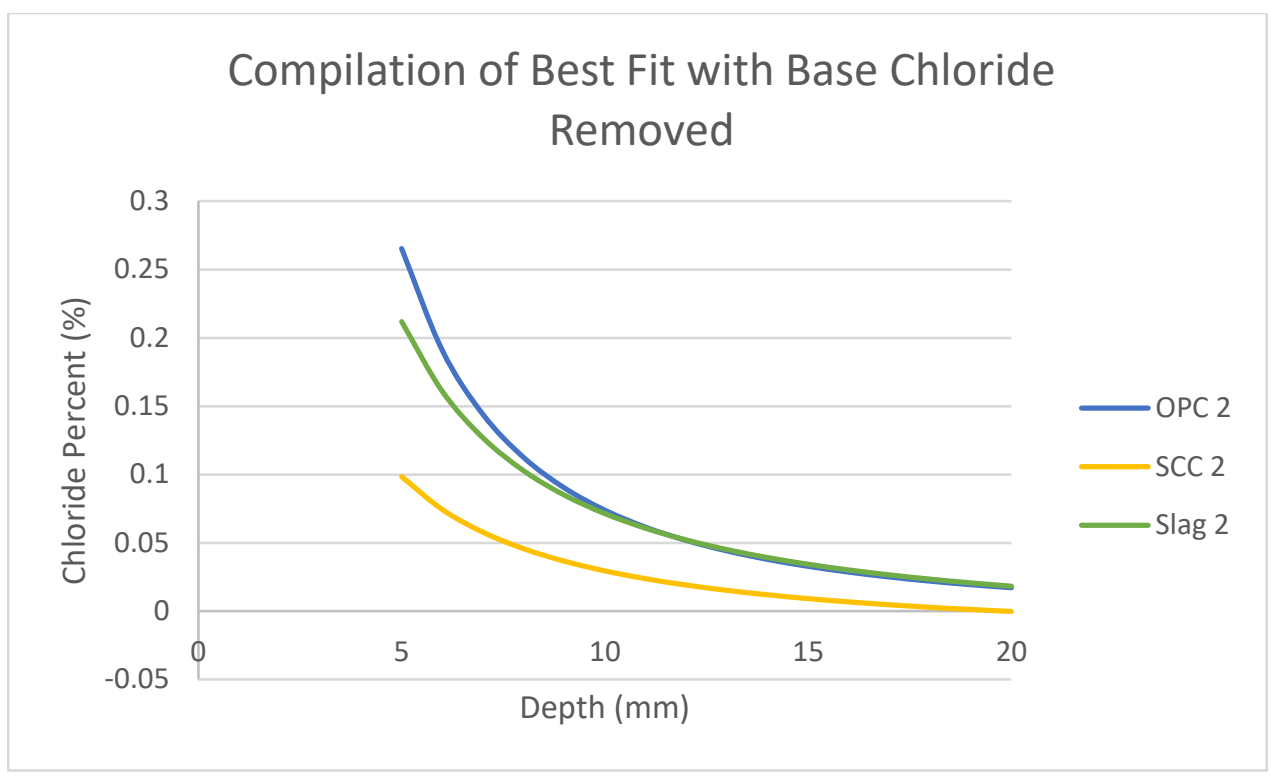

Figure 31: Graph of the concentration of chloride per gram of sample vs. depth (mm), the data is of the best fit line, with the outliners and the base chloride level removed.

The best fit lines from each graph can be used to calculate the chloride diffusion coefficient, to compare to the chloride migration coefficient obtained from the RCPT and silver nitrate testing. The OPC2, Slag2 and SCC2 graphs were used to calculate the chloride diffusion coefficient.

$$
C_{p}=\frac{m}{\sqrt{\pi D t}} \exp \left(-\frac{x^{2}}{4 D t}\right)
$$

Equation 14: Calculation of Chloride Diffusion Coefficient ${ }^{42}$

Where:

$$
\begin{gathered}
\mathrm{m}=\text { total amount of chloride } \\
\mathrm{t}=\text { duration (seconds) } \\
\mathrm{D}=\text { chloride diffusion coefficient }\left(\mathrm{cm}^{2} / \mathrm{s}\right) \\
\mathrm{C}_{\mathrm{p}}=\text { curve fitting equation }
\end{gathered}
$$

\begin{tabular}{|c|c|}
\hline & $\begin{array}{c}\text { Chloride Diffusion } \\
\text { Coefficient }\left(\mathrm{cm}^{2} / \mathrm{s}\right)\end{array}$ \\
\hline OPC2 & $4.78 \mathrm{E}-08$ \\
\hline SCC2 & $1.56 \mathrm{E}-08$ \\
\hline Slag2 & $3.00 \mathrm{E}-08$ \\
\hline
\end{tabular}

Table 12: Chloride Diffusion Coefficient for Ponding Samples. 
From the ponding results, the integral chloride content can be calculated. This value can then be compared to the results from the RCPT, total charge passed (Coulombs). To obtain the chloride integral chloride content value the chloride content $(\%)$ is graphed against the depth (mm), as shown below. ${ }^{44}$ The average chloride content (\%) between each data point is then calculated. The total sum of those values is the integral chloride content.

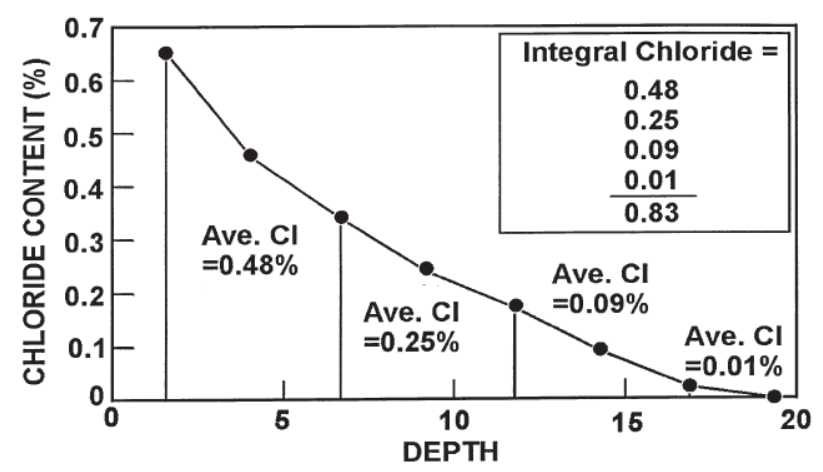

Figure 32: Example of the integral chloride content calculation. (McGrath, 1999)

\begin{tabular}{|c|c|}
\hline & $\begin{array}{c}\text { Integral Chloride } \\
\text { Content }\end{array}$ \\
\hline OPC 1 & 0.6384 \\
\hline OPC 2 & 0.6564 \\
\hline Slag 1 & 0.3270 \\
\hline Slag 2 & 0.6260 \\
\hline SCC 1 & 0.3643 \\
\hline SCC 2 & 0.2975 \\
\hline
\end{tabular}

Table 13: Chloride Integral chloride content for each specimen.

\subsection{RCPT}

The RCPT results created a clear indication of a relationship between OPC, slag, and SCC. The ASTM states that the area under the curve of a current versus time graph can be used to produce a total passed charge amount. The equipment used in this research calculated and displayed a total charge passed throughout the experiment. A graph of total charge passed in Coulombs was also created. 


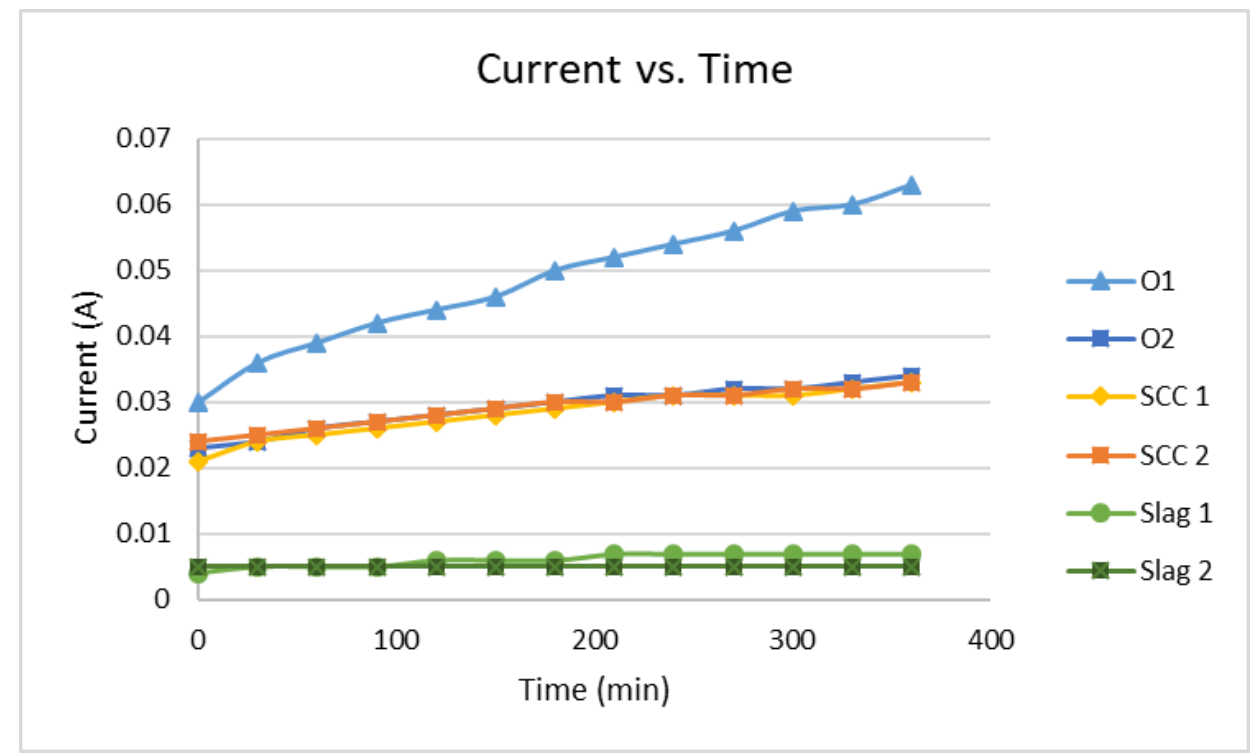

Figure 33: RCPT test results comparing current (A) against time (min).

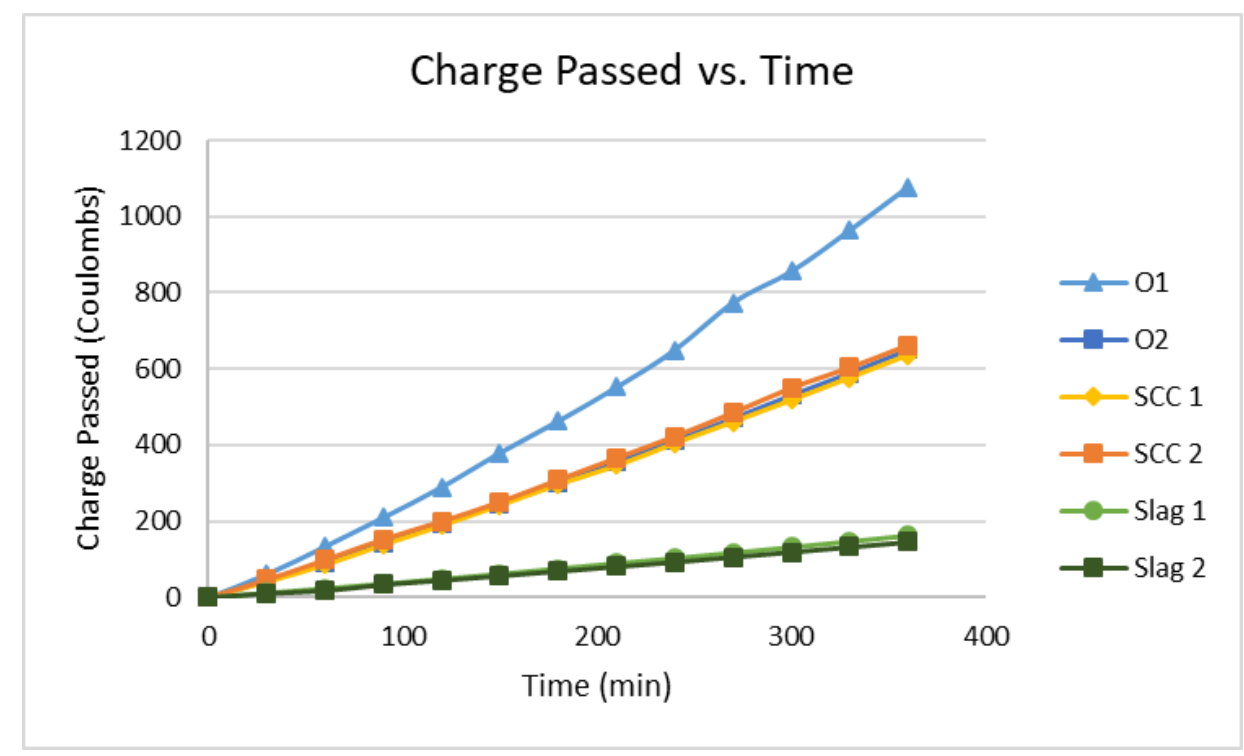

Figure 34: The RCPT data of Charge Passed (Coulombs) versus time (min).

Although the cylinders were of similar depths, they were not all the same length. To fix this issue, a relationship calculation was used to show the current passed through a $51 \mathrm{~mm}$ sample and the charge passed for a $51 \mathrm{~mm}$ sample.

Equation 15: $Q_{s}=Q\left(\frac{d}{51}\right)^{2}$ 
Where:

$\mathrm{Q}_{\mathrm{s}}=$ Charge Passed through a $50 \mathrm{~mm}$ sample (Coulombs)

$\mathrm{Q}=$ Charge Passed from RCPT (Coulombs)

$\mathrm{d}=$ Depth of cylinder $(\mathrm{mm})$

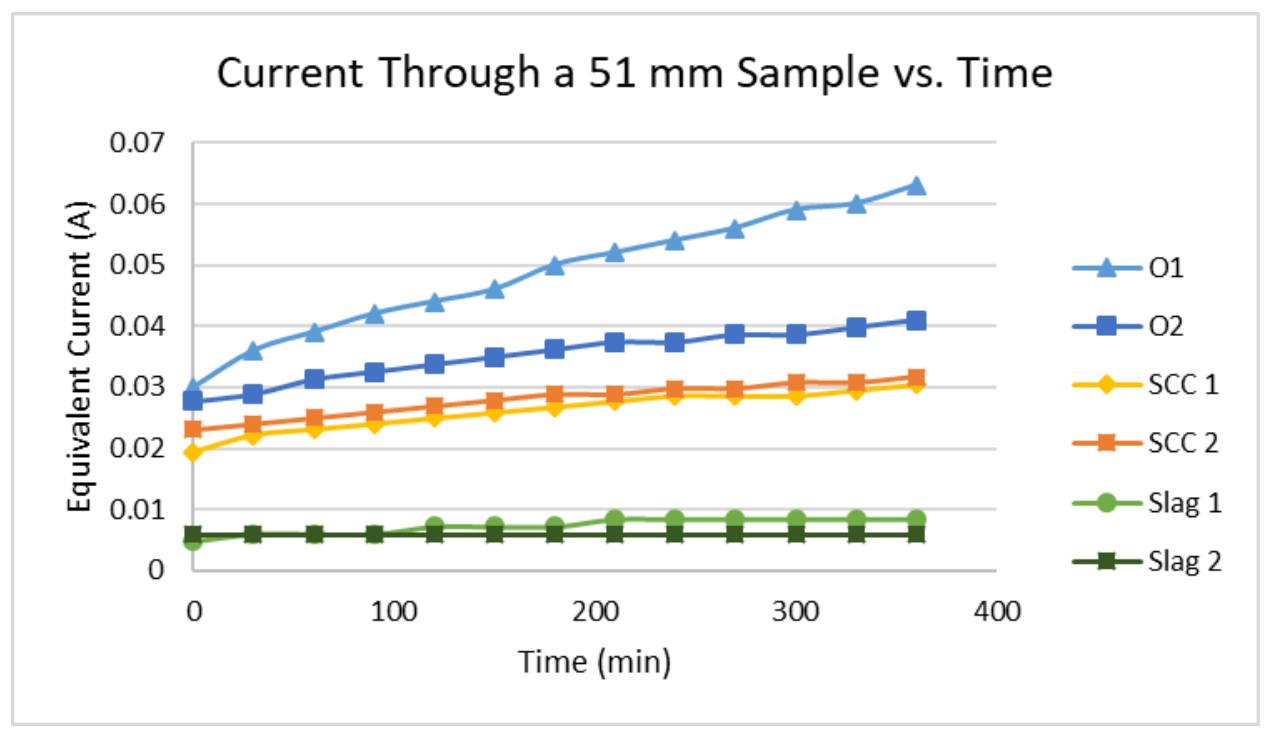

Figure 35: Current Passed Through a 51mm sample versus the time for all samples.

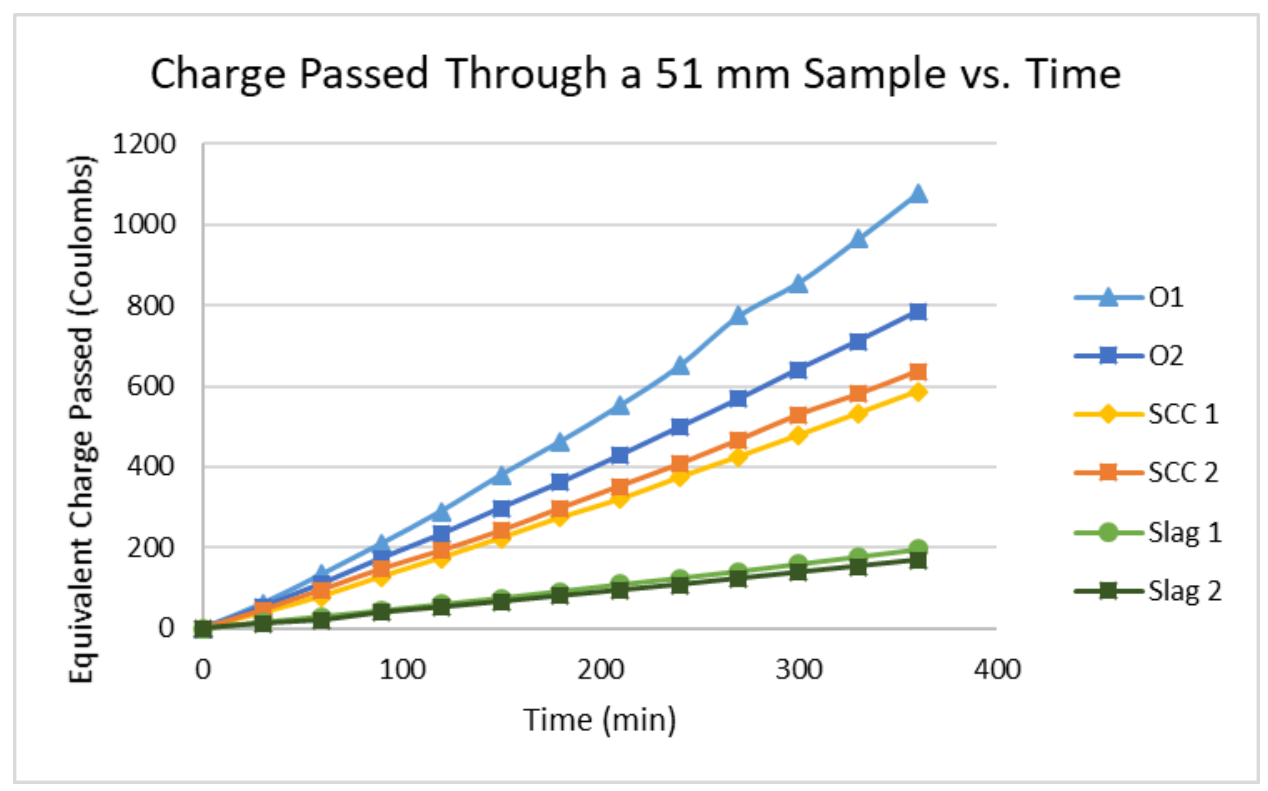

Figure 36: RCPT data of Charged Passed of a 51 mm sample (Coulombs) versus time (min).

The ASTM C12023 uses Table 14 to correlate the relationship between the total passed charge from the RCPT testing to the penetrability of concrete. 


\section{TABLE X1.1 Chloride Ion Penetrability Based on Charge Passed (1)}

\begin{tabular}{ll}
\hline Charge Passed (coulombs) & Chloride lon Penetrability \\
\hline$>4,000$ & High \\
$2,000-4,000$ & Moderate \\
$1,000-2,000$ & Low \\
$100-1,000$ & Very Low \\
$<100$ & Negligible \\
\hline
\end{tabular}

Table 14: ASTM C1202 uses the total passed charge to determine the penetrability of the concrete. ${ }^{3}$

These results indicate that the mix designs for Slag and SCC are considered Very Low penetrability, and showed that the OPC mix design although not a Very Low Penetrability it is still a Low penetrability. These designs would all be considered to have an acceptable permeability.

\subsection{SILVER NITRATE TESTING}

Silver Nitrate Testing is conducted to see the depth at which chloride penetrates during RCPT testing. Once the RCPT data was collected the samples were split, and a $0.1 \mathrm{M}$ Silver Nitrate solution was sprayed to the newly exposed interior. The Silver Nitrate reacts with the free chloride ions to illuminate the depth of Chloride. ${ }^{37}$ The results from these testing can also be used to calculate the chloride migration coefficient.

$$
E=\frac{V-2}{L}
$$

Equation 16: Calculations for the E parameter of the Chloride Migration Coefficient ${ }^{41}$

$$
\begin{gathered}
\text { Where: } \\
\mathrm{V}=\text { External Electrical Voltage } \\
\mathrm{L}=\text { Specimen thickness }(0.051 \mathrm{~m}) \\
\alpha=2 \sqrt{\frac{R T}{z F E} \cdot e r f^{-1}\left(1-\frac{2 C_{d}}{C_{0}}\right)}
\end{gathered}
$$

Equation 17: The formula to obtain the alpha parameter ${ }^{41}$ 
Where:

$\mathrm{R}=$ is the universal gas constant $(8,314 \mathrm{Joule} / \mathrm{mol} / \mathrm{K})$

$\mathrm{T}=$ is the average value of absolute temperature in the anode solution $(\mathrm{K})$

$\mathrm{F}=$ is the Faraday constant $(96480$ coulombs/mol)

$\mathrm{C}_{0}=$ is chloride concentration in the source cell $(\mathrm{mol} / \mathrm{L})$

$\mathrm{C}_{\mathrm{d}}=$ is chloride concentration at which the color change $(0.07 \mathrm{~N} \mathrm{~mol} / \mathrm{L}$ for OPC $)$

$\operatorname{erf}^{-1}=$ the inverse of error function

$\mathrm{z}=$ the ion valence

$$
D_{n s s m}=\frac{R T}{z F E} \cdot \frac{x_{d}-\alpha \sqrt{x_{d}}}{t}
$$

Equation 18: Calculation for the chloride migration coefficient ${ }^{41}$

Where:

$$
\begin{aligned}
\mathrm{X}_{\mathrm{d}} & =\text { depth of penetration }(\mathrm{m}) \\
\mathrm{t} & =\text { time of test (seconds) }
\end{aligned}
$$

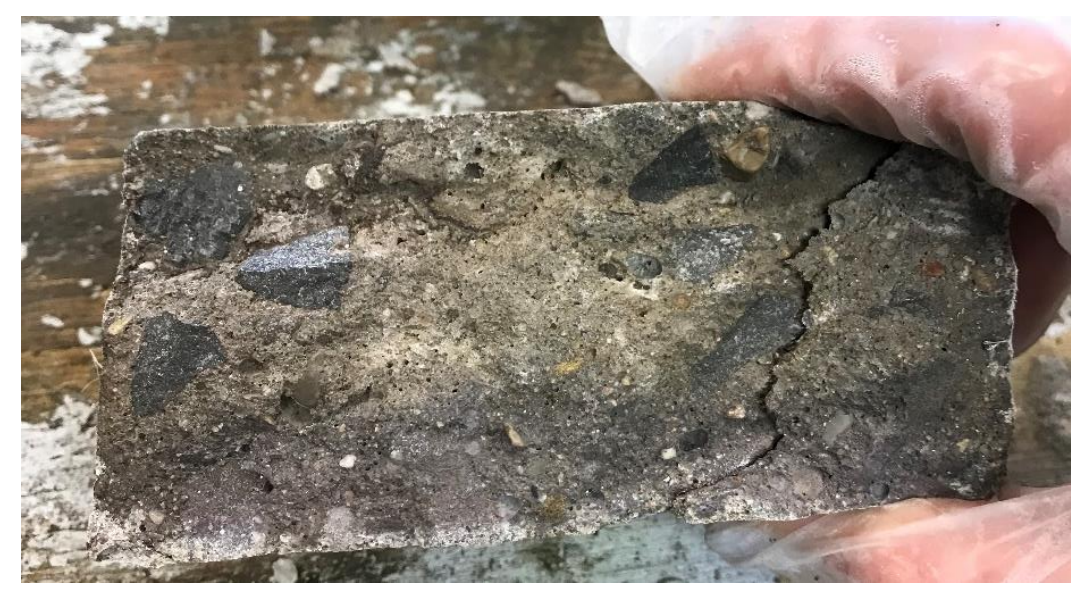

Figure 37: OPC1 RCPT samples after Silver Nitrate was applied. 


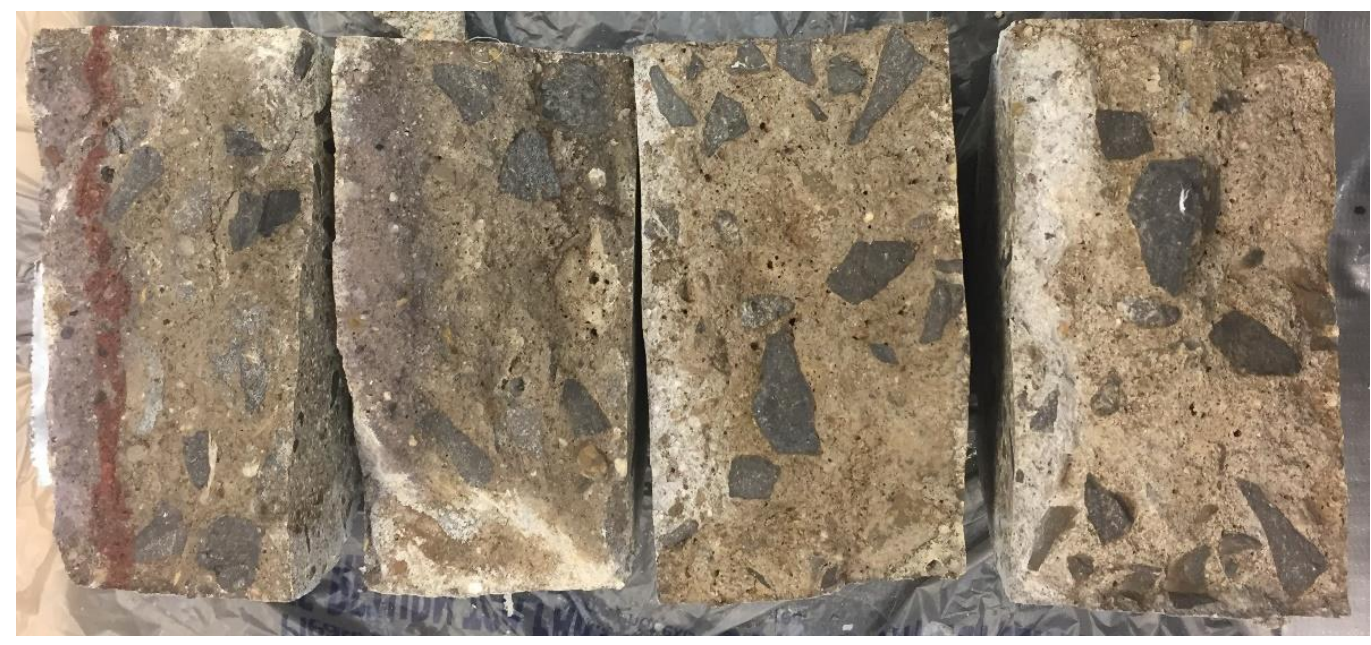

Figure 38: OPC RCPT samples after Silver Nitrate was applied.

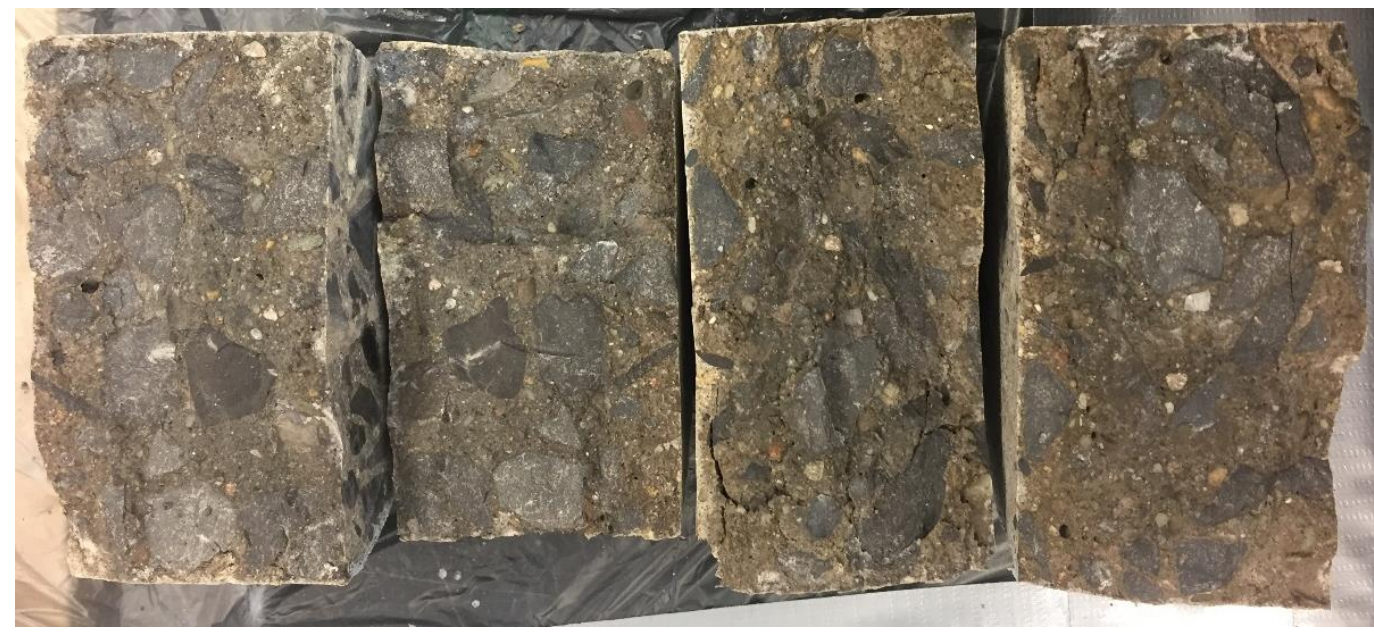

Figure 39: Slag RCPT samples after Silver Nitrate was applied.

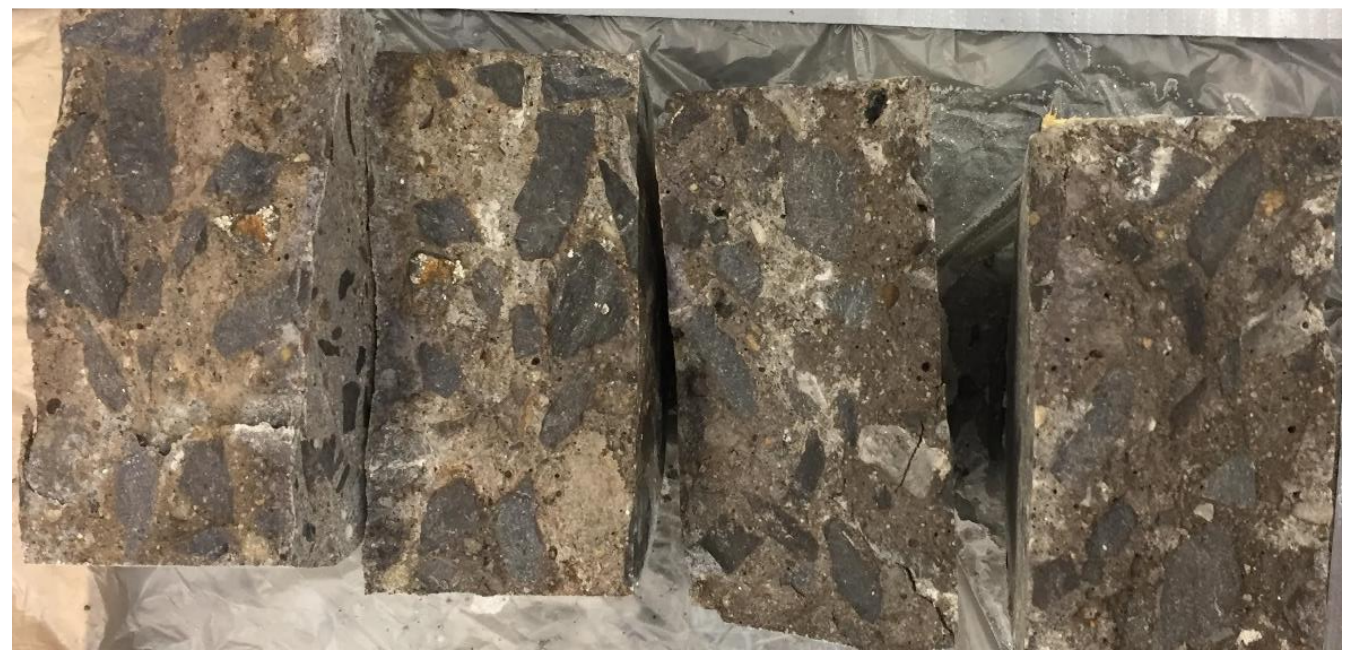

Figure 40: SCC RCPT samples after Silver Nitrate was applied. 


\begin{tabular}{|c|c|c|c|}
\hline & OPC & SCC & SLAG \\
\hline V (Volts) & \multicolumn{3}{|c|}{60.00} \\
\hline$L(m)$ & \multicolumn{3}{|c|}{0.05} \\
\hline $\mathrm{E}($ Volts/m) & 1137.25 & 1137.25 & 1137.25 \\
\hline $\mathrm{R}$ (Joule/mol/K) & \multicolumn{3}{|c|}{8.31} \\
\hline $\mathrm{T}(\mathrm{K})$ & 288.48 & 290.40 & 286.28 \\
\hline F (Coulombs/mol) & \multicolumn{3}{|c|}{$9.65 E+04$} \\
\hline $\mathrm{z}$ & \multicolumn{3}{|c|}{1.00} \\
\hline $\mathrm{Co}(\mathrm{mol} / \mathrm{L})$ & \multicolumn{3}{|c|}{0.51} \\
\hline $\mathrm{Cd}(\mathrm{N} \mathrm{mol} / \mathrm{L})$ & \multicolumn{3}{|c|}{0.07} \\
\hline$e^{\prime \wedge}{ }^{\wedge}-1$ & \multicolumn{3}{|c|}{1.28} \\
\hline$\alpha$ & 0.01 & 0.01 & 0.01 \\
\hline$x d(m)$ & 0.012 & 0 & 0 \\
\hline $\mathrm{t}(\mathrm{sec})$ & \multicolumn{3}{|c|}{21600.00} \\
\hline$D_{\text {nssm }}\left(m^{\wedge} 2 / s\right)$ & $1.082 \mathrm{E}-12$ & 0 & 0 \\
\hline
\end{tabular}

Table 15: Chloride Migration Coefficient for each RCPT testing.

The results show that the depth of chloride in OPC had the highest level of penetration since SCC and Slag had no visible penetration. OPC produced a chloride diffusion value of 1.082E12 for OPC1 and 1.301E-12 for OPC2. These values are essential for predicting the service life of the samples as well as comparing the samples to the ponding results.

\subsection{VIRTUAL PROGRAMS}

Bentz's virtual RCPT program was used to conduct an expected total passed charge value. The program uses the weights $(\mathrm{kg})$ of the aggregates, cementitious material, and water. The program also considers the $\mathrm{SiO}_{2}$ content (\%), specific gravity, fineness $\left(\mathrm{m}^{2} / \mathrm{kg}\right)$, the air content and the estimated pore solution conductivity. The estimated pore solution conductivity was found from the estimated system degree of hydration, the mix design and the $\mathrm{K}_{2} \mathrm{O}$ percentage in the cement. The values used in each mix design and their results are listed below. 


\begin{tabular}{|c|c|c|c|}
\hline & OPC & Slag & SCC \\
\hline Water (kg) & 140 & 127.554 & 168.491 \\
\hline Fine Aggregate (kg) & 844 & 809.229 & 839.486 \\
\hline Course Aggregate (kg) & 968.82 & 1064.931 & 871.523 \\
\hline Cement (kg) & 335 & 150.7 & 436.058 \\
\hline Slag (kg) & 0 & 150.7 & 0 \\
\hline Silica Fume (kg) & 0 & 0 & 44.4957 \\
\hline $\begin{array}{c}\text { Estimated system degree of } \\
\text { hydration (\%) }\end{array}$ & 69.6 & 70.5 & 64.3 \\
\hline $\begin{array}{c}\text { Estimated Pore Solution } \\
\text { Conductivity (S/m) }\end{array}$ & 11.41 & 6.53 & 10 \\
\hline $\begin{array}{c}\text { Predicted Total Charge } \\
\text { Passed (Coulombs) }\end{array}$ & 1837 & 1052 & 159 \\
\hline Chloride lon Penetrability & Low & Low & Very Low \\
\hline $\begin{array}{c}\text { Estimated Effective Water } \\
\text { to Cement Ratio }\end{array}$ & 0.417 & 0.423 & 0.386 \\
\hline
\end{tabular}

Table 16: Constant Values used in Virtual Predictions.

The results from the virtual RCPT testing showed that the OPC mixture had a total passed charge of 1837 (coulombs). When compared to Table 14, the OPC specimens would be considered to have Low chloride ion penetrability. ${ }^{3}$ The SCC total passed charge was 159 (coulombs), this value would have the SCC samples classified as Very Low chloride ion penetrability. ${ }^{3}$ The slag mix design showed a predicted total passed charge of 1052 (coulombs), which would rate the specimen as having Low chloride ion penetrability. ${ }^{3}$ These results would indicate that the samples with SCC mix design have the best permeability, followed by Slag and then OPC. It also would suggest that the replacement of cement with slag and silica fume would benefit the permeability of concrete.

Although this program does account for many aspects of each mix design, it does have a few flaws. One drawback to this program is that the estimated pore solution conductivity is calculated from an estimated degree of hydration and the same mix design. This value can drastically influence the outcome permeability and should be assessed carefully. The other drawback to this program is that it does not account for the curing temperature or the age of the concrete.

Along with Bentz's virtual RCPT, testing is Bentz's virtual service life program which uses an estimation based on Weyers, 1992 research.47 The NIST programs, Prediction of the Chloride Ion Diffusivity of a Concrete Based on Mixture Parameters and Prediction of Service Life of Reinforced Concrete Structure Exposed to Chlorides, is an extension of the RCPT. ${ }^{45,46}$ The first program uses the water-cement ratio, the amount of silica fume, the volume fraction of aggregate and the degree of hydration to predict the chloride ion diffusivity, D. ${ }^{45}$ This program references three of Bentz papers, 2000, 1995 and 1998. ${ }^{48,49,50}$ The parameter D is then used with the factors of the chloride 
profile to predict the service life. For these calculations, the chloride profile values were set constant and are listed below, along with the $\mathrm{D}$ parameter for each mix and its final service life prediction.

\begin{tabular}{|c|c|c|}
\hline $\begin{array}{l}\text { External } \\
\text { chloride } \\
\text { concentration }\end{array}$ & & $4 \mathrm{lb} / \mathrm{yd} \mathrm{d}^{3}$ \\
\hline $\begin{array}{l}\text { Concrete } \\
\text { chloride conc. } \\
\text { needed at } \\
\text { reinforcement } \\
\text { to start } \\
\text { corrosion }\end{array}$ & & $1.2 \mathrm{lb} / \mathrm{yd}^{3}$ \\
\hline $\begin{array}{c}\text { Reinforcement } \\
\text { depth }\end{array}$ & & 2 in \\
\hline $\begin{array}{c}\text { Standard } \\
\text { deviation in } \\
\text { reinforcement } \\
\text { depth }\end{array}$ & & 0.1 in \\
\hline \multirow{3}{*}{$\begin{array}{l}\text { Chloride } \\
\text { Diffusion } \\
\text { Coefficient }\end{array}$} & OPC & $0.0813 \mathrm{in}^{2} / \mathrm{yr}$ \\
\hline & $\mathrm{SCC}$ & $0.0051 \mathrm{in}^{2} / \mathrm{yr}$ \\
\hline & Slag & $0.0273 \mathrm{in}^{2} / \mathrm{yr}$ \\
\hline \multirow{3}{*}{$\begin{array}{l}\text { Time until } \\
\text { initiation of } \\
\text { corrosion }\end{array}$} & OPC & $16 \mathrm{yr}$ \\
\hline & SCC & $252 \mathrm{yr}$ \\
\hline & Slag & $47 \mathrm{yr}$ \\
\hline
\end{tabular}

Table 17: Service life parameters and results. ${ }^{46}$

The results from NIST show an unreasonable service life for SCC. To find the reason why the service life was so high the chloride diffusion coefficient program was run using the recommended values and then altering each parameter one after another to see how increasing the silica fume percentage effects the $\mathrm{D}$ parameter or the chloride diffusion coefficient. The $\mathrm{D}$ parameter can then be used with NIST to find the service life since the D parameter is directly related to the service life. Only the variables used to find the changes in the $\mathrm{D}$ parameter were altered and observed. 


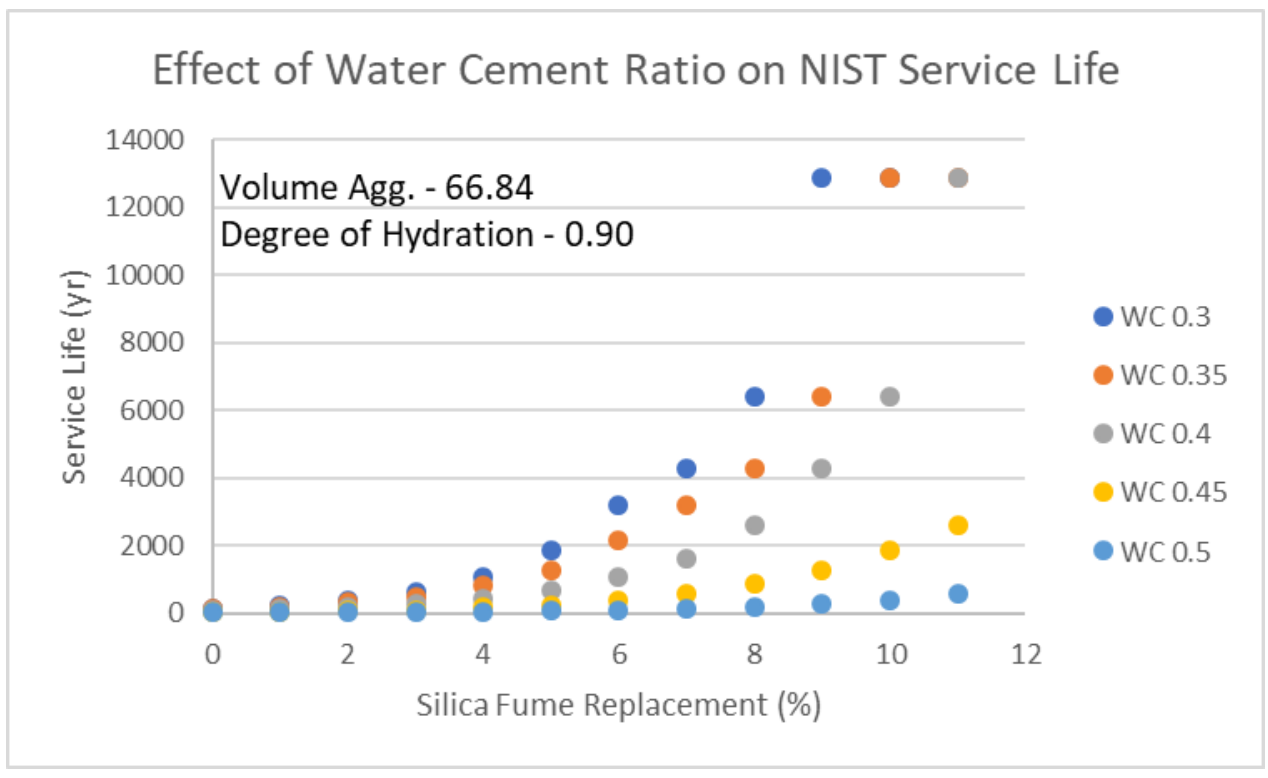

Figure 41: The water cement ratio and the silica fume percent was adjusted to observe the service life.

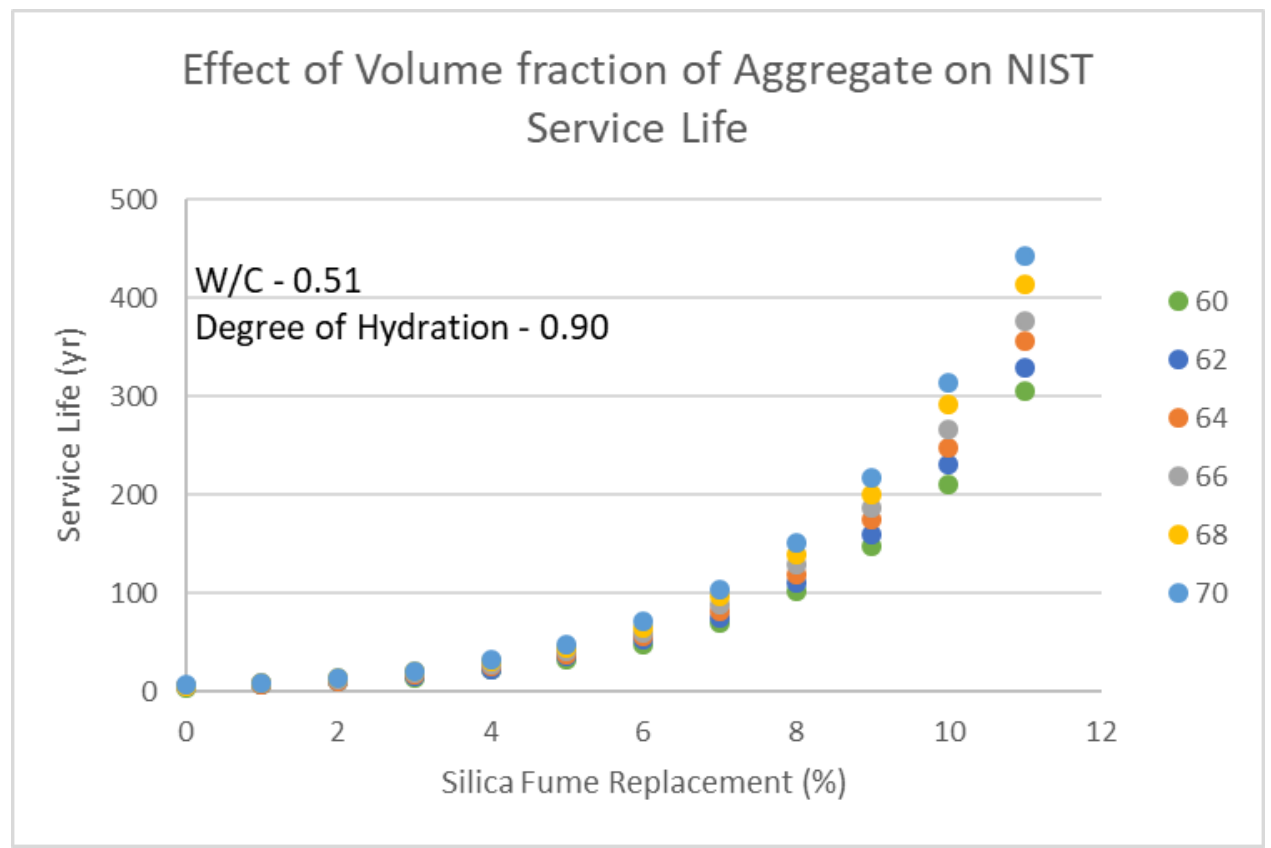

Figure 42: The volume fraction of aggregate and the silica fume replacement was adjusted to observe the service life. 


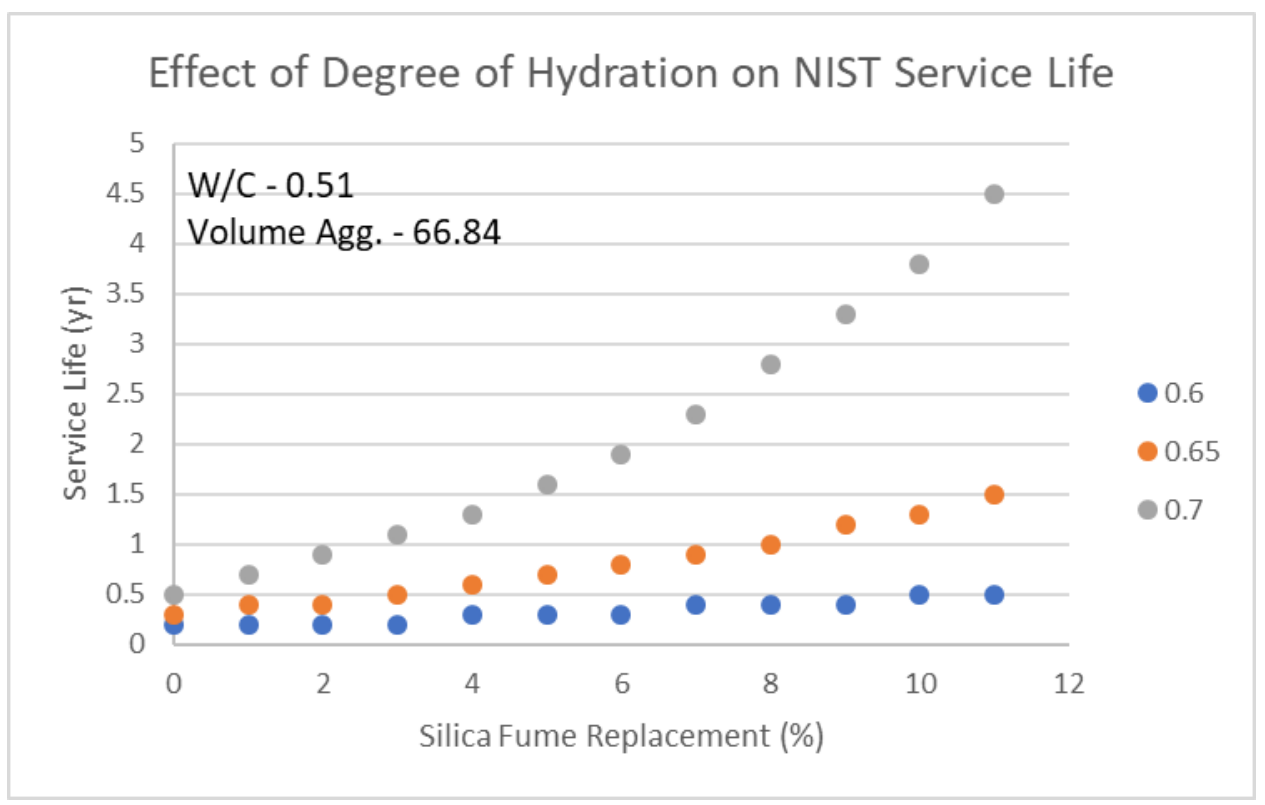

Figure 43: Degree of hydration and silica fume replacement were adjusted to observe the service life.

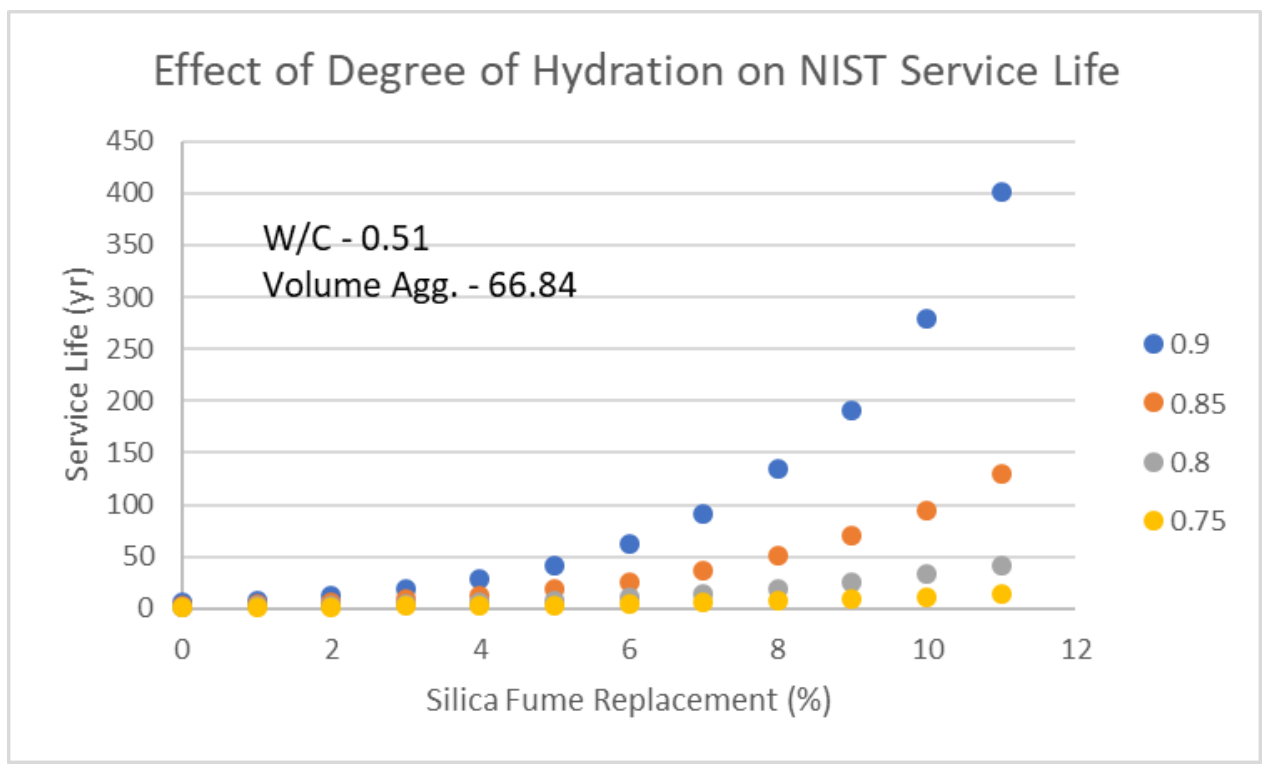

Figure 44: Degree of hydration and silica fume replacement were adjusted to observe the service life. 


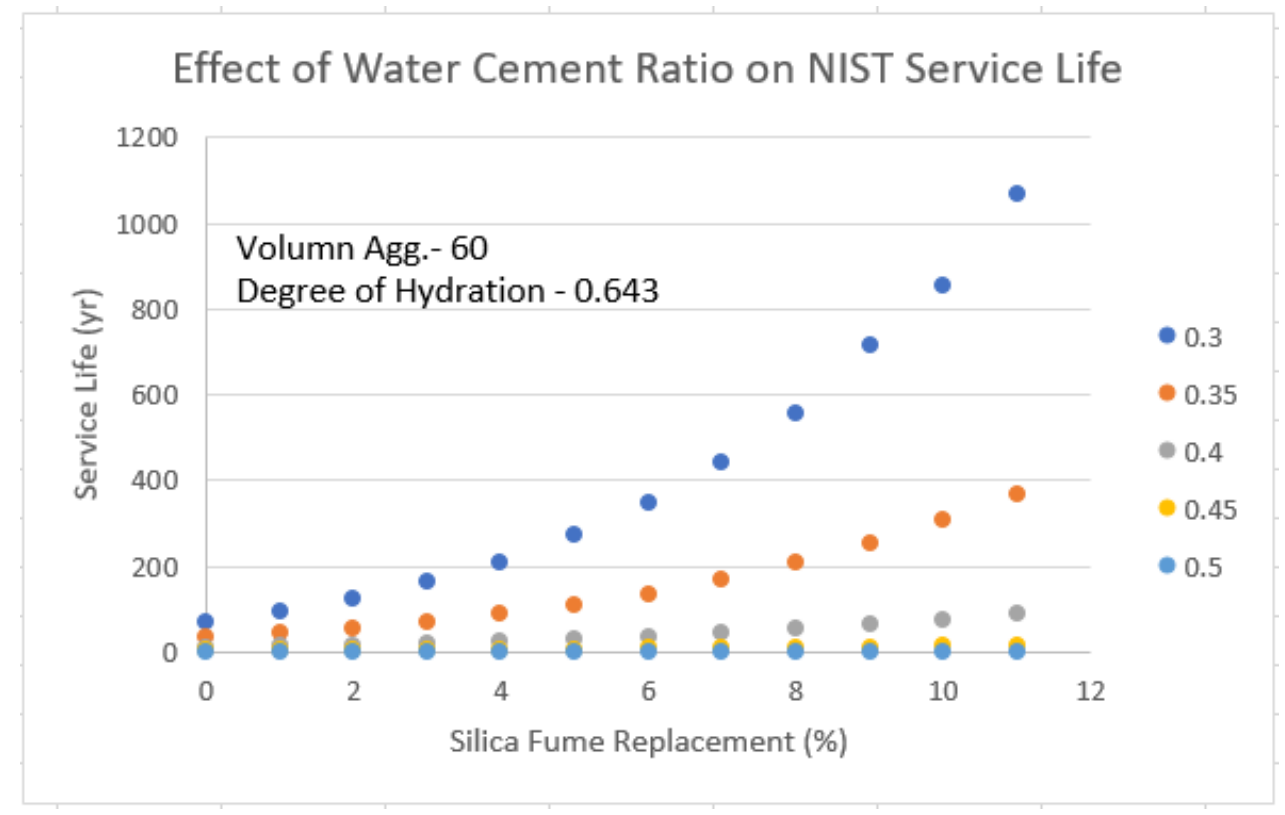

Figure 45: Water cement ratio and silica fume replacement were adjusted to observe the service life.

The results from adjusting the parameters indicate that at all water-cement ratios the service life becomes unreasonable at a high silica fume percentage. The results also suggest that the change in volume fraction of aggregate had little effect on service life but again at a higher silica fume replacement the service life was still unreasonable. Finally, when the degree of hydration was adjusted above 0.8 it became unreasonable at higher silica fume replacement percentages. Due to these results, it is clear why the SCC mix design produces an illogical service life, because of its water-cement ratio and its high silica fume replacement.

\subsection{PONDING AND RCPT CORRELATIONS}

The relationship between the integral chloride content and the charge passed (coulombs) is not a clear correlation but was fitted in McDonald's paper with a regression line to try and indicate a clear linear relationship. ${ }^{43} \mathrm{Y}=6 \mathrm{E}-05 \mathrm{x}+0.1$ represents the regression line. Although the regression line creates the best fit, it does not suggest that there is a clear correlation between the two. This lack of an association follows the results found in McGrath's paper. ${ }^{44}$ 


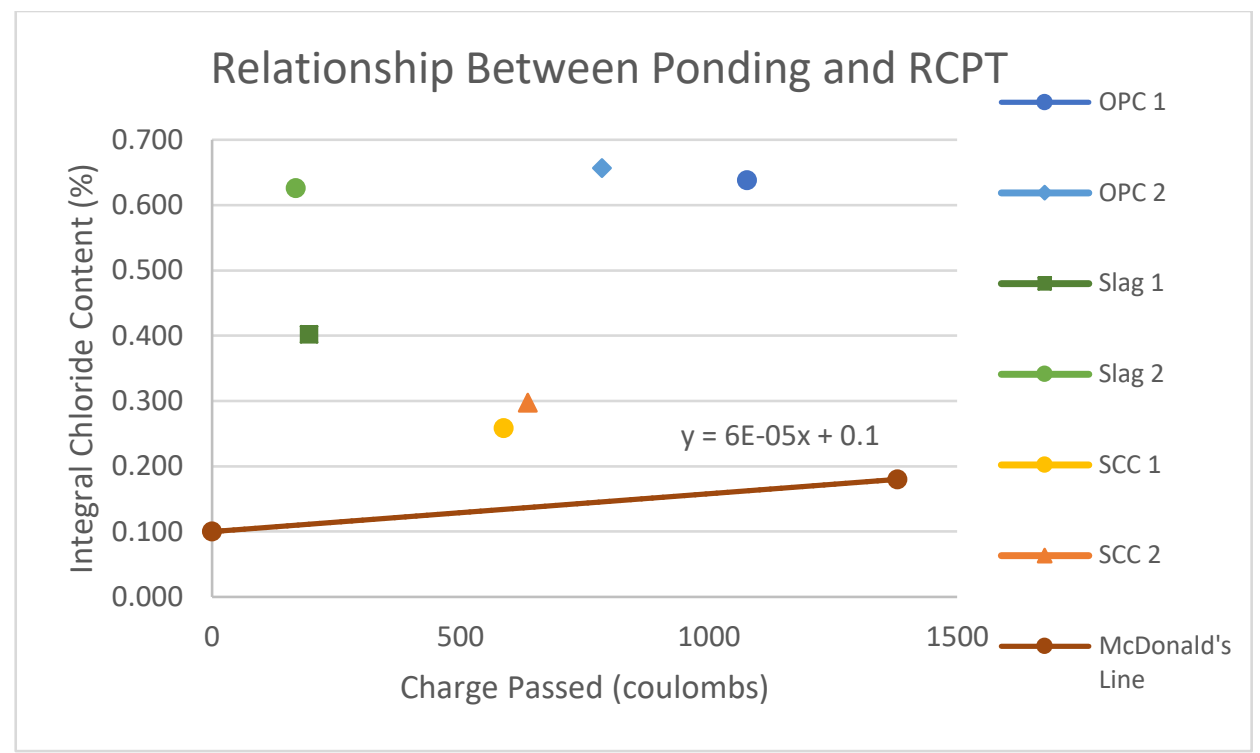

Figure 46: Relationship between integral chloride content and the charge passed (coulombs).

The other relationship, between the ponding and RCPT test results, is a linear correlation between the chloride diffusion coefficient and the chloride migration coefficient. ${ }^{43}$ This relationship is described in Chiang's 2007 paper. $^{43}$ The regression line used in Chain's paper is indicated as $y=3.54 x+.46 .^{43}$ This relationship was only shown for the OPC samples since the SCC and slag samples did not produce any penetration depth from the silver nitrate testing. Although two data points are not enough to validate the relationship, it does follow the same trend.

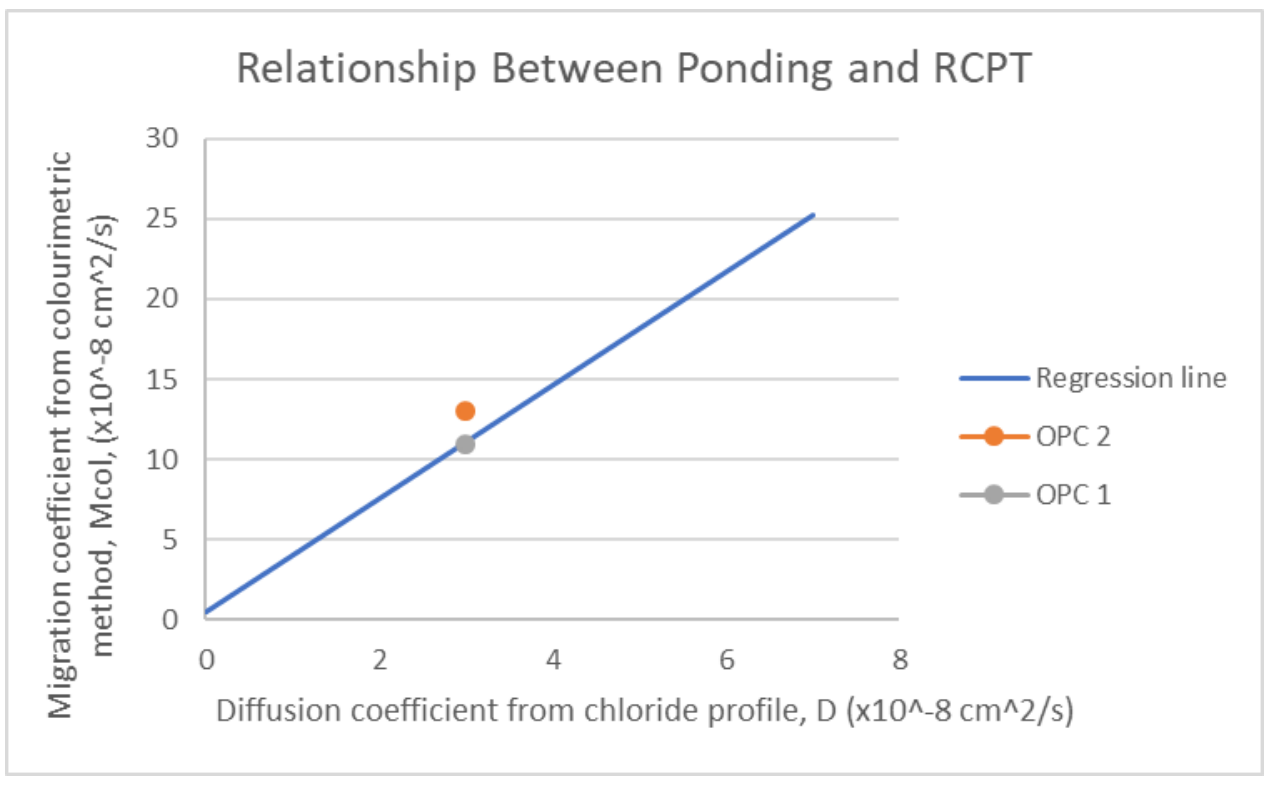

Figure 47: Relationship between Migration coefficient and Diffusion coefficient. ${ }^{43}$ 


\subsection{PERMEABILITY'S EFFECT ON DURABILITY, THROUGH SERVICE LIFE CALCULATIONS}

To determine the service life of each concrete mix design the Life-365 program was used. Life-365 described service life as "the number of years it takes for corrosion of steel to be initiated" plus "the period between initial corrosion to when the concrete needs repair". ${ }^{32}$ The Life-365 program uses the Life-365 method discussed earlier in this paper to replicate the $\mathrm{D}(\mathrm{t})$ function and then generates not only a service life considering the changing penetrability of the concrete but also gives a more regionalized chloride profile. For these testing Charleston, West Virginia was selected as the location, and an urban highway bridges' reinforced slab was considered the sample. A twoinch cover was chosen as the depth of the reinforcement, and this assumption was made from standards used in the field.

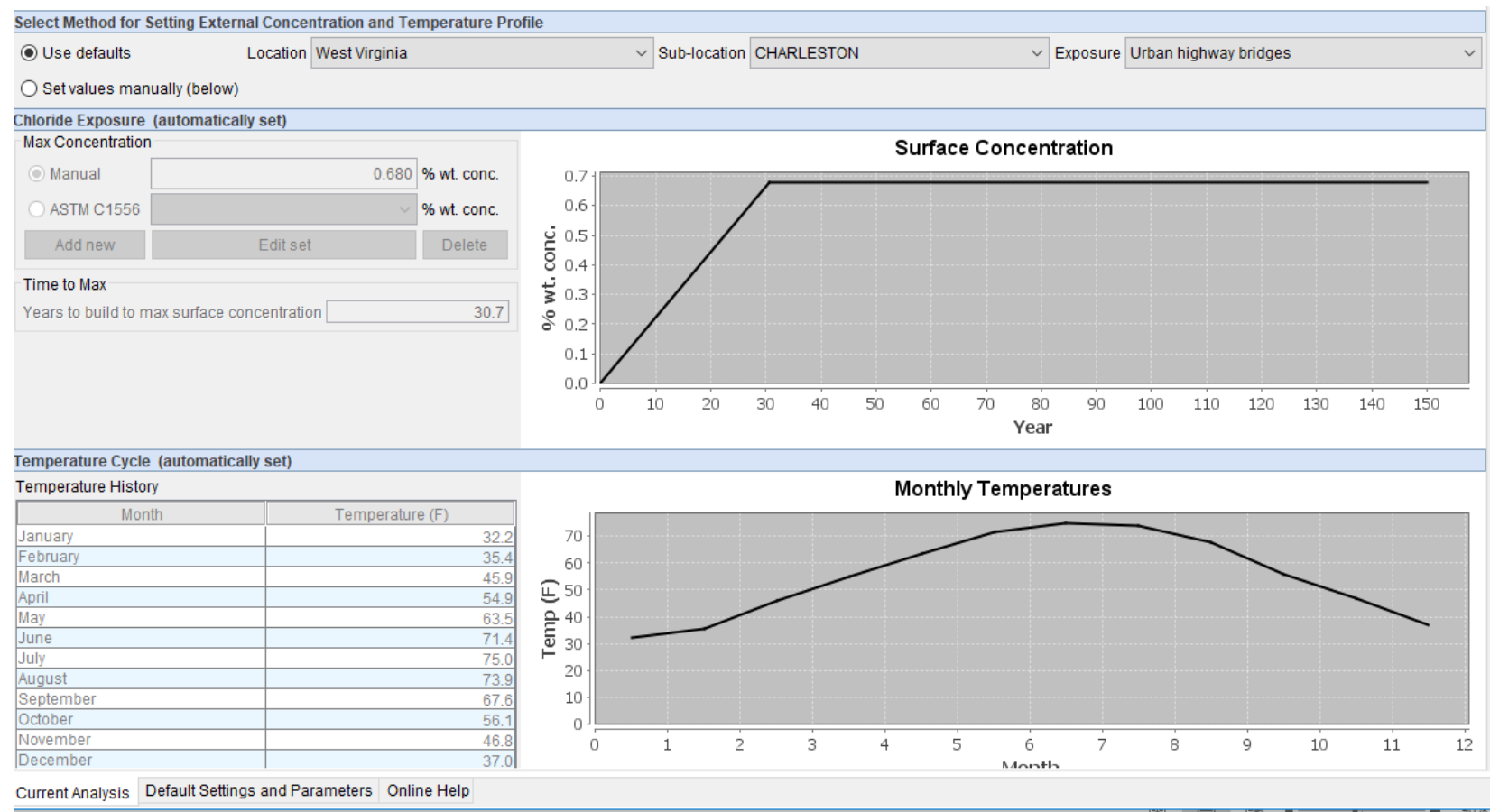

Table 18: Chloride Exposure Prediction for an Urban Bridge in Charleston West Virginia ${ }^{32}$ 


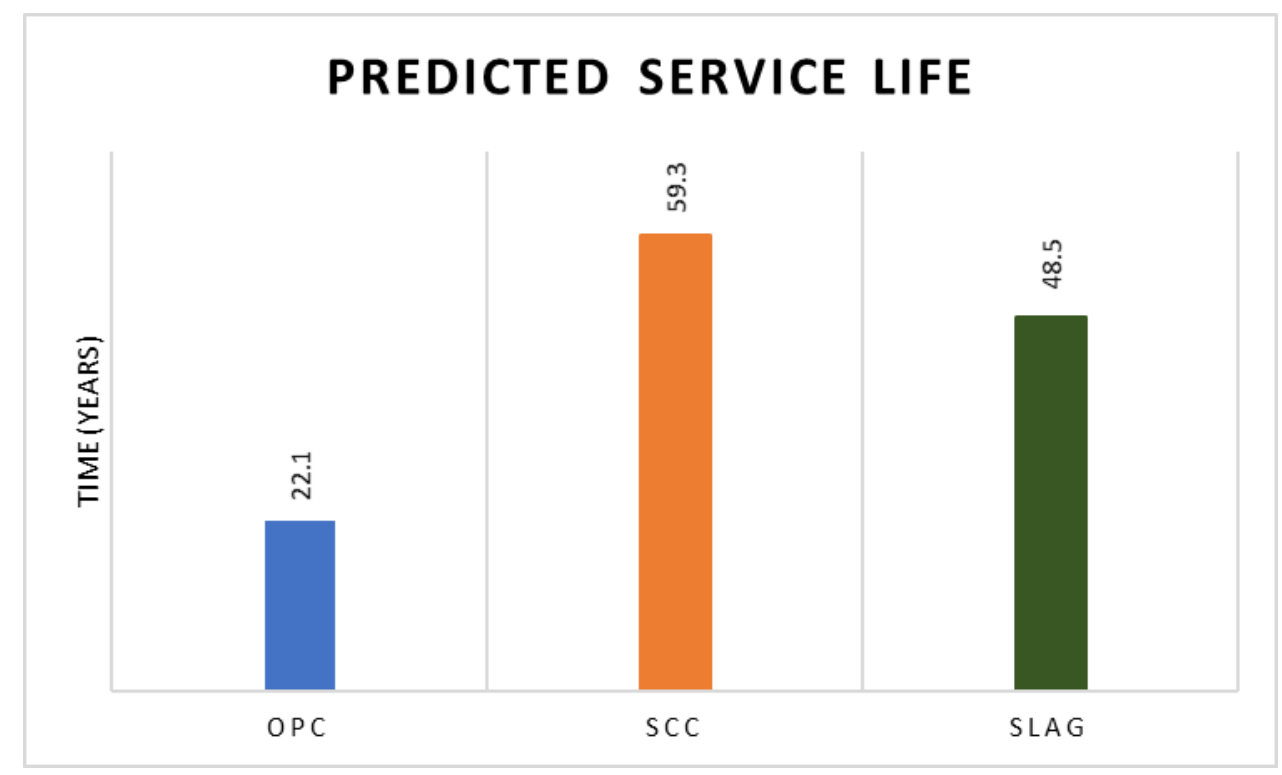

Figure 48: Service Life Estimations, using the Life-365 Program ${ }^{32}$

\begin{tabular}{|c|c|c|}
\hline & $\mathrm{D}\left(\mathrm{in}^{2} / \mathrm{sec}\right)$ & $\mathrm{D}\left(\mathrm{in}^{2} / \mathrm{yr}\right)$ \\
\hline OPC & $1.3012 \mathrm{E}-08$ & 0.410346 \\
\hline SCC & $2.1155 \mathrm{E}-09$ & 0.066714 \\
\hline Slag & $1.3751 \mathrm{E}-08$ & 0.433652 \\
\hline
\end{tabular}

Table 19: Chloride Diffusion coefficient predictions. ${ }^{32}$

Based on the results from the Life-365 program it shows that both a 50\% slag replacement and a 9\% silica fume addition will increase the service life of the concrete. The increase was over double the service life of an OPC concrete slab. The increase in service life shows that the SCC and slag mix designs have more durability than the OPC counterpart.

Although this model is very well designed and does consider a changing chloride profile, it doesn't consider a vastly changing mix design. The program asks for an input value of the cementation materials and the water-cement ratio of each mix design. Although this does allow for the substitution of slag and silica fume to be modeled, it does not account for the different admixtures, the air content, or the varying aggregate size which could affect the overall service life and thus durability of the concrete. The program produces the chloride diffusion coefficient, which is dramatically higher than the predictions from the NIST program.44 This difference could explain why the two service life predictions do not match. 


\subsection{DISCUSSIONS}

Although previous research may have created reliable predictions of the permeability of these mixtures, it is still important to conduct the tests to be confident that the new class-M concrete performs as predicted. To better understand the relationship between tests a collection of chloride diffusion coefficients obtained in this study is shown in Table 20. To compare the RCPT test results the linear relationship between the chloride diffusion coefficient and the chloride migration coefficient was used to obtain a D value for OPC. Again, the D value could not be obtained for SCC and slag from the RCPT results because the chloride migration coefficient could not be determined from silver nitrate test results.

\begin{tabular}{|c|c|c|c|c|}
\hline \multirow{2}{*}{} & \multicolumn{4}{|c|}{$\mathrm{D}\left(\mathrm{in}^{\wedge} 2 / \mathrm{yr}\right)$} \\
\cline { 2 - 5 } & Life-360 & NIST & Ponding & *RCPT \\
\hline OPC & 0.410346432 & 0.0813 & 0.2336507 & 0.1591 \\
\hline SCC & 0.066714408 & 0.0051 & 0.0762542 & - \\
\hline Slag & 0.433651536 & 0.0273 & 0.146643 & - \\
\hline
\end{tabular}

Table 20: Chloride diffusion coefficient comparison. *The values for RCPT came from the correlation between chloride migration coefficient and chloride diffusion coefficient.

The service life was also compared between the NIST program and the Life-360 software. The results indicate that OPC has a service life in the range of 16-22 years. Slag has a service life range between $47-48.5$ years, and SCC has a range of 60-252 years.

\begin{tabular}{|c|c|c|}
\hline & NIST (years) & Life-360 (years) \\
\hline OPC & 16 & 22.1 \\
\hline SCC & 252 & 59.3 \\
\hline Slag & 47 & 48.5 \\
\hline
\end{tabular}

Table 21: Comparison of service life results from both programs. 


\section{CHAPTER 6: CONCLUSION AND RECOMMENDATIONS}

\subsection{CONCLUSIONS}

The permeability of concrete was tested for OPC, SCC, and slag using multiple methods. The results from ponding, virtual RCPT, and Life-365 showed that the SCC had the lowest permeability and OPC had the highest permeability. However, the results from RCPT showed that the slag had the lowest permeability and OPC had the highest permeability. Virtual RCPT and experimental RCPT indicate that both SCC and slag are in the very low permeability zone and that OPC is in the low permeability zone. All four tests show that the alternative versions of concrete performed better than the OPC for permeability.

The service life indicates that OPC has a service life in the range of 16-22 years. Slag has a service life range between 47-48.5 years, and SCC has a range of 60-252 years. The results show that OPC has the lowest service life range when looking at chloride permeability. Although the results for the NIST service life is unreasonably high for SCC, both programs indicate that SCC produces the largest service life.

\subsection{RECONMENDATIONS}

There are additional factors that could account for the lack of correlations. For results to be conclusive, the tests should be redone with a few elements changed. Firstly, ponding should be repeated with lab grade $\mathrm{NaCl}$. Secondly, ponding samples should be suspended during the ponding time frame, and ponding samples should all be tested with 10 grams of powdered samples.

The RCPT testing should be redone when the temperature outside is warmer to allow the labs to be within the appropriate temperature range during the experiment. With the temperature inside of the proper range, it will enable the change in temperature to be more accurately recorded, which is essential in the RCPT testing. The assumptions made in the virtual RCPT testing should also be reexamined, by obtaining the chemical composition of both the slag and silica fume, so that the values can be as accurate as possible.

To continue the research the next step would be to redo the already completed testing's, to verify the findings, and to test the fly ash mix design. Another way to advance this research would be to test the ponding samples with not only the probe but also with a chemical titration process to verify that the probe method is as effective as the ASTM standards. These results could then be definitively accepted or denied.

To better determine the service life of each mix design the freeze-thaw durability should be tested. In past testing, the freeze-thaw durability showed that the SCC mix design had low durability. These tests should be used to determine the overall service life. Unfortunately, the equipment was broken during this research, so the freeze-thaw tests could not be completed. 


\section{VITA}

Amelia Suzanne Riley was born and raised in Hedgesville, West Virginia. She graduated top ten of her class from Hedgesville High School in 2012. She then attended West Virginia Wesleyan College, where she obtained her degree in Applied Physics in 2016. After which she moved to Morgantown, WV in 2016 to attended West Virginia University to earn a Master of Science in Civil Engineering with a concentration in structures. In May 2018 she met all requirements for the degree. 
1) ASTM Standard C470/C470M-15, 2003, "Standard Specification for Molds for Forming Concrete Test Cylinders Vertically," ASTM International, West Conshohocken, PA, 2015, DOI: 10.1520/C0033-03, www.astm.org.

2) ASTM Standard C1543-10a, 2010, "Standard Test Method for Determining the Penetration of Chloride Ion into Concrete by Ponding," ASTM International, West Conshohocken, PA, 2010, DOI: 10.1520/C0033-03, www.astm.org.

3) ASTM Standard C1202-12, 2012, "Standard Test Method for Electrical Indication of Concrete's Ability to Resist Chloride Ion Penetration," ASTM International, West Conshohocken, PA, 2015, DOI: 10.1520/C0033-12, www.astm.org.

4) ASTM Standard C457/C457M-16, 2016, " Standard Test Method for Microscopical Determination of Parameters of the Air-Void System in Hardened Concrete," ASTM International, West Conshohocken, PA, 2015, DOI: 10.1520/C0033-03, www.astm.org.

5) “Air Entrainment versus Air Entrapment." NPCA National Precast Concrete Association, 20 Dec. 2012, https://precast.org/2012/12/air-entrainment-versus-air-entrapment/

6) Pozzolanic reaction in portland cement, silica fume, and fly ash mixtures

$J K W$ eng, $B W$ Langan, $M A W$ ard

https://doi.org/10.1139/197-025

7) "Scientific Principles." Concrete: Scientific Principles, matse1.matse.illinois.edu/concrete/prin.html.

8) Thomas, M. D. A. Optimizing the Use of Fly Ash in Concrete. Portland Cement Association, 2007.

9) Naik, Tarun R. Concrete Durability as Influenced by Density and/ or Porosity . 1997, Concrete Durability as Influenced by Density and/ or Porosity . says, Ralph Ramirez, et al. "Air Entrainment versus Air Entrapment." National Precast Concrete Association., 20 Dec. 2012, precast.org/2012/12/air-entrainment-versus-air-entrapment/.

10) "Mission \& History." Slag Cement Association, www.slagcement.org/home/missionhistory.aspx.

11) Bilir, Turhan. "Effects of Non-Ground Slag and Bottom Ash as Fine Aggregate on Concrete Permeability Properties."

12) “Lafarge at a Glance.” Lafarge.com, 6 Aug. 2015, www.lafarge.com/en/lafarge-at-a-glance

13) Sfikas, Ioannis P. "Self-Compacting Concrete: History \& Current Trends." Research Gate, www.researchgate.net/publication/317345607 SelfCompacting Concrete History Current Trends

14) Jau, W.-C., and D.-S. Tsay. "A Study of the Basic Engineering Properties of Slag Cement Concrete and Its Resistance to Seawater Corrosion." Cement and Concrete Research, vol. 28, no. 10, 1998, pp. 1363-1371., doi:10.1016/s0008-8846(98)00117-3. 
15) Yu, Zhuqing, and Guang Ye. "The Pore Structure of Cement Paste Blended with Fly Ash." Construction and Building Materials, vol. 45, 2013, pp. 30-35., doi:10.1016/j.conbuildmat.2013.04.012.

16) ASTM Standard C231/C231M-17a, 2016, " Standard Test Method for Air Content of Freshly Mixed Concrete by the Pressure Method," ASTM International, West Conshohocken, PA, 2015, DOI: 10.1520/C0033-03, www.astm.org.

17) ASTM Standard C39/C39M-18, 2018, " Standard Test Method for Compressive Strength of Cylindrical Concrete Specimens," ASTM International, West Conshohocken, PA, 2015, DOI: 10.1520/C0033-03, www.astm.org.

18) ASTM Standard C496/C496M-17, 2017, " Standard Test Method for Splitting Tensile Strength of Cylindrical Concrete Specimens," ASTM International, West Conshohocken, PA, 2015, DOI: 10.1520/C0033-03, www.astm.org.

19) ASTM Standard C42/C42M-16, 2016, " Standard Test Method for Obtaining and Testing Drilled Cores and Sawed Beams of Concrete," ASTM International, West Conshohocken, PA, 2015, DOI: 10.1520/C0033-03, www.astm.org.

20) ASTM Standard C143./C143M-15, 2015, " Standard Test Method for Slump of HydraulicCement Concrete," ASTM International, West Conshohocken, PA, 2015, DOI: 10.1520/C0033-03, www.astm.org.

21) ASTM Standard C192/C192M-02, 2002, " Standard Practice for Making and Curing Concrete Test Specimens in the Laboratory," ASTM International, West Conshohocken, PA, 2015, DOI: 10.1520/C0033-03, www.astm.org.

22) ASTM Standard C1152/C1152M-04, 2012," Standard Test Method for Acid-Soluble Chloride in Mortar and Concrete," ASTM International, West Conshohocken, PA, 2015, DOI: 10.1520/C0033-03, www.astm.org.

23) ASTM Standard C1611/C1611M-14, 2014, " Standard Test Method for Slump Flow of SelfConsolidating Concrete," ASTM International, West Conshohocken, PA, 2015, DOI: 10.1520/C0033-03, www.astm.org.

24) ASTM Standard D515-12, 2012, " Standard Test Method for Chloride Ion In Water," ASTM International, West Conshohocken, PA, 2015, DOI: 10.1520/C0033-03, www.astm.org.

25) "Portland Cement." Wikipedia, Wikimedia Foundation, 16 Mar. 2018, en.wikipedia.org/wiki/Portland_cement.

26) ASTM Standard C150/C150M-16, 2016, " Standard Specification for Portland Cement," ASTM International, West Conshohocken, PA, 2016, DOI: 10.1520/C0033-03, www.astm.org.

27) "Composition, Specifications and Conformity Criteria for Common Cements." EUROPEAN STANDARD, EN 197-1, June 2000.

28) Torrent, Robert J. "Service Life Prediction: Theorecrete, Labcrete and Realcrete Approaches ." Claisse, www.claisse.info/2013\%20papers/data/e577.pdf.

29) Song, Zhengtian, and Martyn Jones. "Enhancing the Service Life of Concrete Exposed to Chloride Attack." University of Dundee. 
30) Bentz, Dale P. “A Virtual Rapid Chloride Permeability Test.” Cement and Concrete Composites, vol. 29, no. 10, 2007, pp. 723-731., doi:10.1016/j.cemconcomp.2007.06.006.

31) Nilsson, Lars Olof. "Models for Chloride Ingress into Concrete - from Collepardi to Today." International Journal of Modelling, Identification and Control, vol. 7, no. 2, 2009, p. 129., doi:10.1504/ijmic.2009.027065.

32) “Life-365.” Life-365, 2.2.3, National Ready Mixed Concrete Association, Concrete Corrosion Inhibitor Association, Slag Cement Association and the Silica Fume Association, Jan. 2018, www.life-365.org/download.html.

33) ASTM Standard C125-18, 2018, " Standard Terminology Relating to Concrete and Concrete Aggregates"

34) "History of SCC History-of-Scc." History of SCC | Sika Corporation U.S., usa.sika.com/en/solutions_products/Construction-Products-Services/Concrete/scczone/history-of-scc.html.

35) "The European Guidelines for Self-Compacting Concrete Specification, Production and Use ."Http://Www.efnarc.org, The European Precast Concrete Organisation, The European Cement Association, The European Ready-Mix Concrete Organisation, The European Federation of Concrete Admixture Associations, The European Federation of Specialist Construction Chemicals and Concrete Systems. , May 2005, www.efnarc.org/pdf/SCCGuidelinesMay2005.pdf.

36) “Split Tensile Strength Test Of Concrete.” Construction Cost Estimating, www.quantitytakeoff.com/split-tensile-strength-concrete.htm.

37) Ma, Zhanxiao. "Durability Investigation of Self Consolidating Concrete Used in the Stalnaker Run Bridge.” West Virginia University, Department of Civil and Environmental Engineering, pp. 23-24.

38) "History of Portland Cement." Concrete Thinker, Concrete Thinking for a Sustainable World, Portland Cement Association, www.concretethinker.com/detail/History-PortlandCement.aspx.

39) Grant, John. Experiments on the Strength of Cement, Chiefly in Reference to the Portland Cement Used in the Southern Main Drainage Works. Spon, 1875.

40) "A History of Cement." Rumford, Portland Cement Association, www.rumford.com/articlemortar.html.

41) “CONCRETE, MORTAR AND CEMENT-BASED REPAIR MATERIALS: CHLORIDE MIGRATION COEFFICIENT FROM NON-STEADY-STATE MIGRATION EXPERIMENTS." Nordtest Method, NT Build 492.

42) Yang, C.C. and Cho, S.W., "The Relationship between Chloride Migration Rate for Concrete and Electrical Current in Steady State Using the Accelerated Chloride Migration Test," Materials and Structures, Vol. 37.

43) Chiang, C.t., and C.c. Yang. "Relation between the Diffusion Characteristic of Concrete from Salt Ponding Test and Accelerated Chloride Migration Test.” Materials Chemistry and Physics, vol. 106, no. 2-3, 2007, pp. 240-246., doi:10.1016/j.matchemphys.2007.05.041. 
44) Mcgrath, Patrick F., and R.doug Hooton. "Re-Evaluation of the AASHTO T259 90-Day Salt Ponding Test." Cement and Concrete Research, vol. 29, no. 8, 1999, pp. 1239-1248., doi:10.1016/s0008-8846(99)00058-7.

45) "Service Life Prediction.” NIST, concrete.nist.gov/ciks/svlf0001.html.

46) Bentz, D. P. "Prediction of the Chloride Ion Diffusivity of a Concrete Based on Mixture Parameters." NIST: Chloride Diffusivity vs. Mix Parameters, concrete.nist.gov/ciks/clcp0001.html.

47) Weyers, R.E., Fitch, M.G., Larsen, E.P., Al-Qadi, I.L., Chamberlin, W.P., and Hoffman, P.C., "Service Life Estimates," SHRP-S-688, Strategic Highway Research Program, National Research Council, 1992.

48) Bentz, D.P., Influence of Silica Fume on Diffusivity in Cement-Based Materials II. MultiScale Modeling of Concrete Diffusivity, Cement and Concrete Research, 30 (7), 1121 1129,2000 .

49) Bentz, D.P., Detwiler, R.J., Garboczi, E.J., Halamickova, P., and Schwartz, L.M., Multi-Scale Modelling of the Diffusivity of Mortar and Concrete, RILEM International Conference on Chloride Intrusion into Concrete, 1995.

50) Bentz, D.P., Garboczi, E.J., and Lagergren, E.S., Multi-Scale Microstructural Modeling of Concrete Diffusivity: Identification of Significant Variables, Cement, Concrete, and Aggregates, 20 (1), 129-139, 1998. 